Portland State University

PDXScholar

1987

\title{
Stratigraphic model of the southern portion of the Jim Bridger coal field, Sweetwater County, Wyoming
}

Paul S. Maywood

Portland State University

Follow this and additional works at: https://pdxscholar.library.pdx.edu/open_access_etds

Part of the Geology Commons

Let us know how access to this document benefits you.

\section{Recommended Citation}

Maywood, Paul S., "Stratigraphic model of the southern portion of the Jim Bridger coal field, Sweetwater County, Wyoming" (1987). Dissertations and Theses. Paper 3719.

https://doi.org/10.15760/etd.5603

This Thesis is brought to you for free and open access. It has been accepted for inclusion in Dissertations and Theses by an authorized administrator of PDXScholar. Please contact us if we can make this document more accessible: pdxscholar@pdx.edu. 
AN ABSTRACT OF THE THESIS OF Paul $S$. Maywood for the Master of Science in Geology presented July 14, 1987.

Title: Stratigraphic Model of the Southern Portion of the Jim Bridger Coal Field, Sweetwater County, Wyoming.

APPROVED BY MEMBERS OF THE THESIS COMMITTEE:

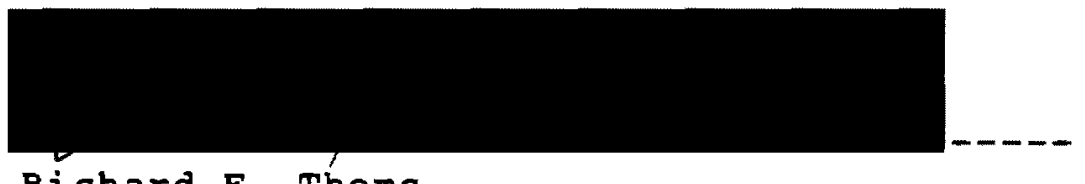

Richard E. Thoms

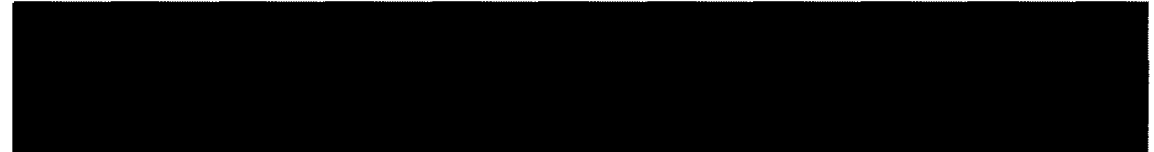

Robert 0 . Van Atta

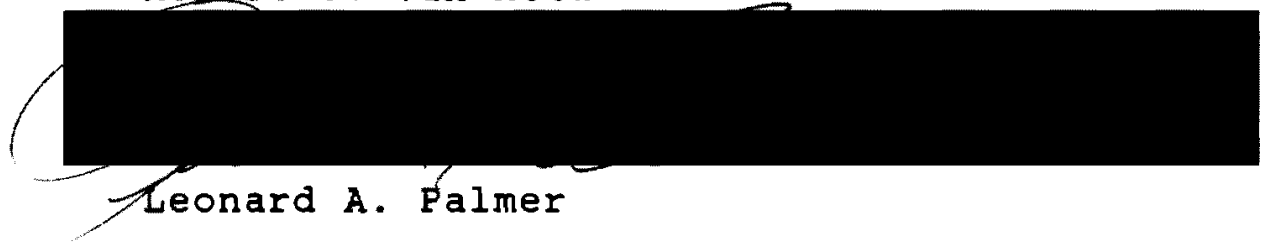

Uppermost Lance and lowermost Fort Union Formation sediments are found in outcrop in the southern portion of the Jim Bridger coal field, located on the northeast flank of the Rock springs uplift in Sweetwater county, Wyoming. Twenty-nine surface sections and 581 subsurface (borehole) sections were evaluated and used to construct a stratigraphic model.

Stratigraphic correlations with economically mineable coal seams in the Fort Union Formation north and south of the study area combined with definition of questionable local formational boundary locations are significant objec- 
tives of this investigation.

Sandstone (60\%), claystone (17\%), siltstone (11\%),

coal $(10 \%)$, and limestone $(2 \%)$ are found to be the most abundant lithologic units and exhibit a high degree of lateral and vertical variability. Lateral continuity of major coal seams is shown to be useful for informal chronostratigraphic purposes.

Fossil flora examined in and near the study area indicate accumulation under warm temperate to subtropical conditions. Flora identified include Cornus nebrascensis (dogwood), Selaginella (fern), Salvinia (floating fern), Cercidiphylium (katsura), and Sabalites (palm).

The Lance-Fort Union contact is mapped immediately above a distinctive fossil soil horizon up to 2.2 meters (7.2 feet) thick, but multiple paleosols exist within the lower Fort Union, so the formational contact is placed below the lowest significant coal, where present. High sandstone percentages and a noticeable lack of lateral accretion surfaces are interpreted to define sedimentation in low sinuosity, perhaps braided, stream environments. Raised peat swamps and high annual precipitation contributed to an elevated water table which inhibited clastic influx and promoted floral development and channel stability. Paleocurrent directions infer a northerly source, probably the wind River Range. 
STRATIGRAPHIC MODEL OF THE

SOUTHERN PORTION OF THE JIM BRIDGER COAL FIELD,

SWEETWATER COUNTY, WYOMING

by

PAUL S. MAYWOOD

A thesis submitted in partial fulfillment of the requirements for the degree of

MASTER OF SCIENCE

in

GEOLOGY

Portland state University 
TO THE OFFICE OF GRADUATE STUDIES AND RESEARCH:

The members of the Committee approve the thesis of Paul S. Maywood presented July 14, 1987.

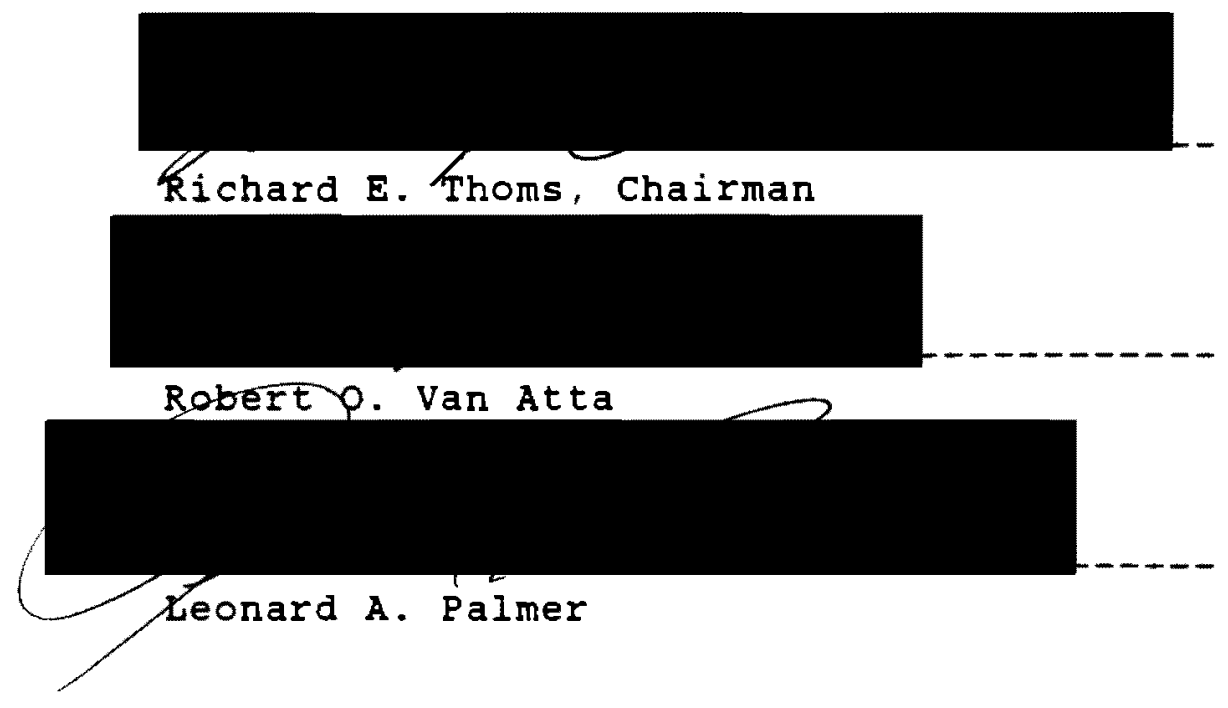

APRROVED :

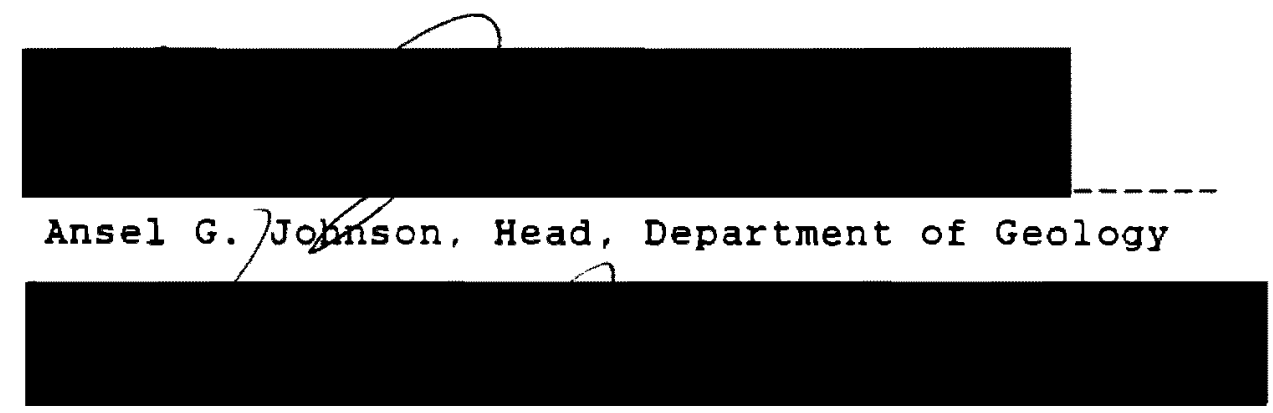

Bernard Ross, Vice Provost for Graduate studies 


\section{ACRNOWLEDGMENTS}

The author gratefully acknowledges the contributions of many individuals to this thesis. Special appreciation is extended to Mark Rirschbaum and Rich Baldwin, U.S. Geological Survey, and David Anderson, San Jose State University, for their help and suggestions in the field. Scott wing, Dept. of Paleobiology, National Museum of Natural History, and Steve Manchester, Paleobotany Laboratory, Indiana University were most helpful on plant fossil identifications. Mark Ostlind, Cartographic services, NERCo Coal Corp., st. Louis, was instrumental in preparation of the geologic maps. Chuck Bowen, Glenrock Coal Co., graciously reviewed a copy of the rough draft.

Sincere thanks to my advisor, Dick Thoms, for his critical review and advice in the field and prompt attention to rough draft chapters. Steve Rosene and Don Gibboney secured a leave of absence for me from Bridger to attend my final term of classes during Winter Quarter, 1986.

Several other professionals need to be recognized for their efforts, without whose help this thesis would have been greatly prolonged or not have been completed. These are Paul Hammond, Portland State University, Mark Bricker and Ruth Bess, Bridger Coal Co. No one, however, deserves more credit than Betty ordway, who not only contributed much needed technical assistance, but also her love, support, understanding and assistance throughout "the project." 
This volume is dedicated to Mike Jaworski, the dynamic geologist who showed me the way. 
TABLE OF CONTENTS

PAGE

ACKNOWLEDGMENTS . . . . . . . . . . . . . . . . .

LIST OF FIGURES . . . . . . . . . . . . . . . . . . viii

LIST OF PLATES. . . . . . . . . . . . . . . . . $\mathrm{x}$

CHAPTER 1 . . . . . . . . . . . . . . . . . . . . 1

INTRODUCTION . . . . . . . . . . . . . 1

PURPOSE AND SCOPE . . . . . . . . . . . . . . 1

LOCATION AND ACCESSIBILITY . . . . . . . . 2

PREVIOUS INVESTIGATIONS . . . . . . . . . 5

CURRENT COAL MINING OPERATIONS . . . . . . . 8

METHODS OF INVESTIGATION . . . . . . . . . 12

CHAPTER 2 . . . . . . . . . . . . . . . . 15

REGIONAL GEOLOGY . . . . . . . . . . . . . 15

TECTONIC SETTING . . . . . . . . . . . . . 15

REGIONAL STRATIGRAPHY . . . . . . . . . . 17

Subjacent Units . . . . . . . . . . 18

Fort Union Formation . . . . . . . . . 21

Superjacent Units . . . . . . . . . 22

GEOLOGIC HISTORY . . . . . . . . . . . . . . . 23

CHAPTER 3 . . . . . . . . . . . . . . . . . . 29

DATA COLLECTION . . . . . . . . . . . . . . 29

AIRPHOTO INTERPRETATION . . . . . . . . . . 29

MEASURED SURFACE SECTIONS . . . . . . . . . 30

SUBSURFACE SECTIONS . . . . . . . . . . . . 33 
PAGE

Exploration and Development

Rotary Holes... . . . . . . . . 33

Continuous Core Holes . . . . . . . 35

PALEOCURRENT MEASUREMENTS . . . . . . . . . . 39

CHAPTER 4 . . . . . . . . . . . . . . . . . . . . . 40

ANALYTICAL PROCEDURES . . . . . . . . . . . 40

CODING OF LITHOLOGIC DATA . . . . . . . . 40

GRAPHIC LOGS. . . . . . . . . . . . . . . 4 41

COAL SEAM CORRELATIONS . . . . . . . . . . 43

PREPARATION OF CROSS-SECTIONS . . . . . . . 45

CHAPTER 5 . . . . . . . . . . . . . . . . . . . . . 46

STRATIGRAPHIC MODEL . . . . . . . . . . . . . 46

LITHOSTRATIGRAPHIC SUMMARY . . . . . . . . . 47

Lithology and Facies Patterns . . . . . 47

CHRONOSTRATIGRAPHY . . . . . . . . . . . 53

PALEOBOTANY . . . . . . . . . . . . . . 50

CHAPTER 6 . . . . . . . . . . . . . . . . . 65

DISCUSSION AND INTERPRETATION . . . . . . . 65

Lance-Fort Union Contact . . . . . . 65

Structural Regime . . . . . . . . 70

MODES OF DEPOSITION . . . . . . . . . . 70

Fort Union Formation, Powder

River Basin . . . . . . . . . 72

Southern Portion of the Jim

Bridger Coal Field. . . . . . . . 74 
PAGE

CHAPTER 7 . . . . . . . . . . . . . . . . . . . . 78

APPLICATION OF STRATIGRAPHIC MODEL . * . . . . 78

CONCLUSIONS AND RECOMMENDATIONS . . . . . . . 79

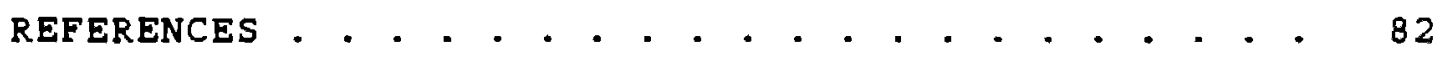

APPENDIX 1 . . . . . . . . . . . . . . . . . . . . . . . 92

MEASURED SURFACE SECTIONS . . . . . . . . . . . 92

APPENDIX 2 . . . . . . . . . . . . . . . . . . . . . 108

SELECTED SUBSURFACE SECTIONS . . . . . . . . . 108

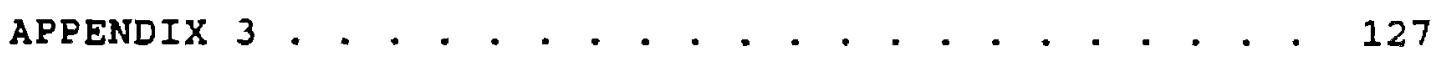

PALEOCURRENT DATA . . . . . . . . . . . . . . 127 


\section{LIST OF FIGURES}

FIGURE

PAGE

1. Major Wyoming coal-bearing areas . . . . . . 3

2. Jim Bridger mine areas . . . . . . . . . . . 4

3. Area of investigation . . . . . . . . . . 7

4. Jim Bridger power plant . . . . . . . . . . 9

5. Generalized cross section of mineable seams, Jim Bridger Mine . . . . . . . . 10

6. Large walking dragline exposing coal . . . . 13

7. Structural features of southwestern Wyoming . . . . . . . . . . . . . . 16

8. Composite erosional columnar section . . . . 24

9. Low cuestas of Fort Union and Lance Formations . . . . . . . . . . . . . 31

10. Section measuring with Brunton and Jacob's staff. . . . . . . . . . . . . 32

11. Transportable rotary drilling rig used

to make exploration boreholes . . . . . . 34

12. Geophysical log suite . . . . . . . . . 36

13. Overburden core photograph . . . . . . . . 38

14. Graphic log plot . . . . . . . . . . . . 42

15. Coal seam correlation (STRATVIEW) plot . . . 44

16. Sandstone types I and III. . . . . . . . . 48

17. Siltstones and claystones in surface section . . . . . . . . . . . 50 
PAGE

18. Well exposed coal seam in the Tenmile Draw area. . . . . . . . . . . . . 52

19. Generalized stratigraphic cross section showing chronologic units . . . . . . . 55

20. Fossil soil at base of Fort Union

Formation in section 35, T20N, R100W . . 57

21. Cornus nebrascensis from section 26 ,

T20N, R10OW................ . 61

22. Selaginella sp. from section 35, T21N, R100W . . . . . . . . . . . . 61

23. Sabalites sp. from section 34, T21N, R100W................. . . 63

24. Generalized cross section through Upper Cretaceous and Lower Tertiary rocks, east flank of the Rock Springs Uplift. . . 69 25. Paleocurrent directions, northwest portion of study area . . . . . . . . 76 


\section{LIST OF PLATES}

PLATE

PAGE

I. Geologic map, northern $2 / 3$ of the Rock

Springs Uplift . . . . . . . . . . in pocket

II. Geologic map, southern portion of

Jim Bridger coal field . . . . . . in pocket

III. Fence diagram . . . . . . . . . . . in pocket 


\section{CHAPTER 1}

\section{INTRODUCTION}

Exploration and exploitation of Wyoming coal deposits in the vicinity of Rock Springs has, until the late 1970's, occurred almost exclusively in the Late Cretaceous Rock Springs Formation. Increasing electric power demands and location of potentially mineable Fort Union Formation coal deposits on the northeast flank of the Rock Springs Uplift justify detailed stratigraphic analysis of these deposits. Limited drilling data during the 1970's inhibited extensive subsurface analysis. However, the procurement of substantial borehole information in the 1980's makes possible detailed stratigraphic studies which correlate subsurface data with surface exposures.

\section{PURPOSE AND SCOPE}

The purposes of this investigation were to define the geology of the southern portion of the Jim Bridger coal deposit and to produce a stratigraphic model. Construction of the model was accomplished by integrating borehole interpretation with outcrop mapping.

A major objective has been to provide lithologic-stratigraphic correlations such that geology and engineering planning staffs at the Bridger mine can evaluate mining potential. The stratigraphic model will 
be used to show structural effects, facies changes, and rock body interrelationships. The southern portion of the Jim Bridger coal field is currently scheduled to undergo development in 1989 (M. Knapton, 1986, assistant mine engineer, Bridger Coal Co., pers. comm.).

\section{LOCATION AND ACCESSIBILITY}

The Jim Bridger coal deposit lies on the northeast flank of the Rock Springs Uplift in Sweetwater County, southwestern Wyoming. Figure 1 places Jim Bridger in perspective with other major coal-bearing areas and drainage basins in the state. The area under permit to mine contains approximately 78 square kilometers (28 square miles) and is located just a few kilometers west of the Continental Divide. Major drainages within the permit area are Deadman Draw, $91 / 2$ Mile Draw, and Tenmile Draw (Figure 2), all of which drain into Bitter Creek, which in turn drains into the Green River. This investigation encompasses the $91 / 2$ and Tenmile South areas within the permit area of Figure 2 .

The area of investigation includes section 36 and the southeastern half of section $35, T 21 \mathrm{~N}, \mathrm{R} 100 \mathrm{~W}$, and sections $4,9,10,14,22,23,26$, and 35 of $T 20 N, R 100 \mathrm{~W}$, and portions of sections $3,5,8,11,13,15$, and $27, T 20 \mathrm{~N}, \mathrm{R} 100 \mathrm{~W}$ (Figure 2). The study area consists of about 34.7 square kilometers (12.5 square miles).

Access to the area is excellent. Interstate 80 passes 


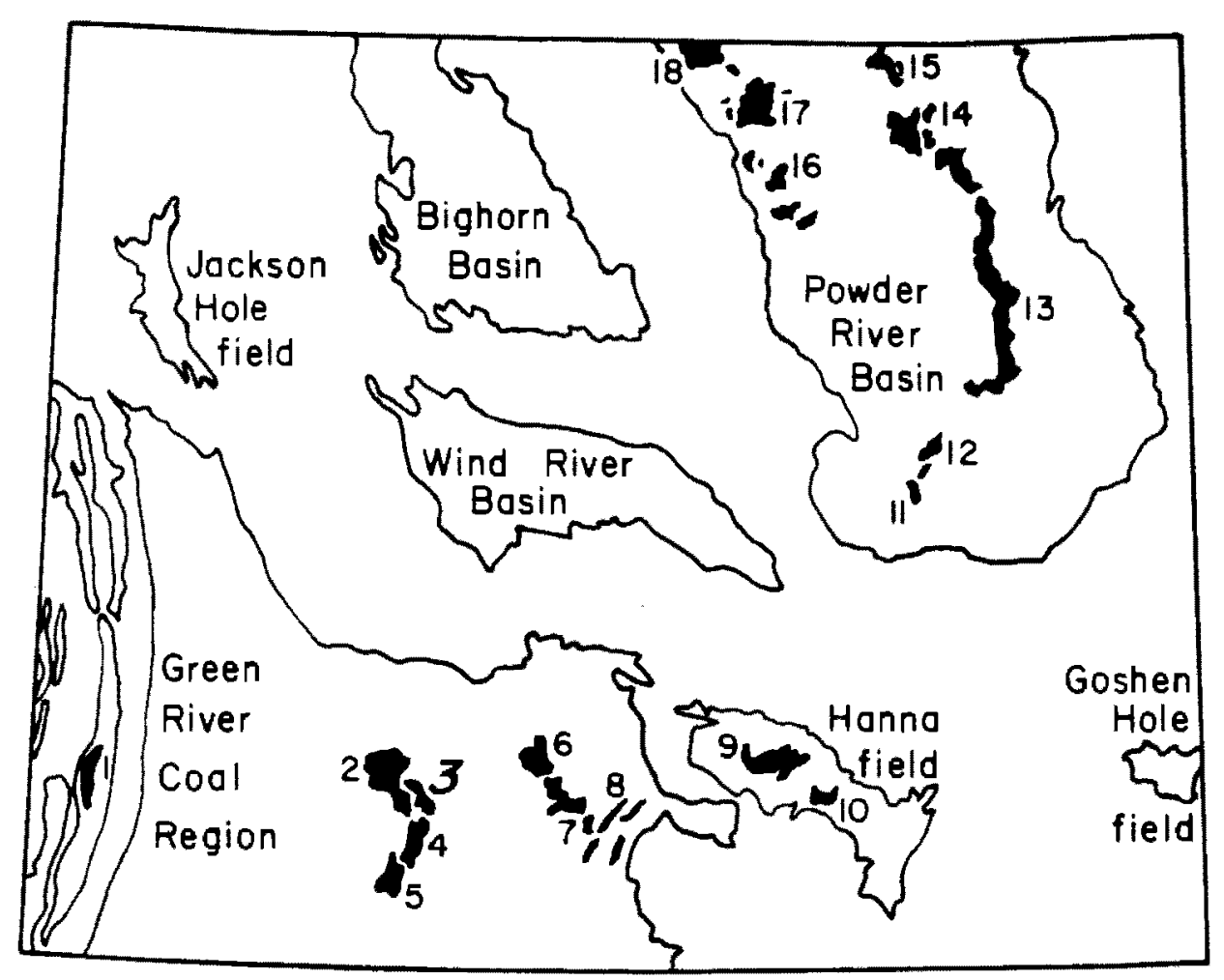

Wtrippable Deposits

1 Adaville

2 Leucite Hills

3 JIM BRIDGER

4 Black Butte

5 Salt Wells

6 Red Desert

7 Cherokee

8 Northern Little Snake River

9 Hanna
10 Carbon

11 Dave Johnston

12 Dry Cheyenne

13 Wyodak

14 Spotted Horse

15 Clear Creek

16 Lake DeSmet

17 Wyarno-Verona

18 Acme-Rleenburn

Figure 1. Major Wyoming coal-bearing areas. Simplified from Glass (1978). 


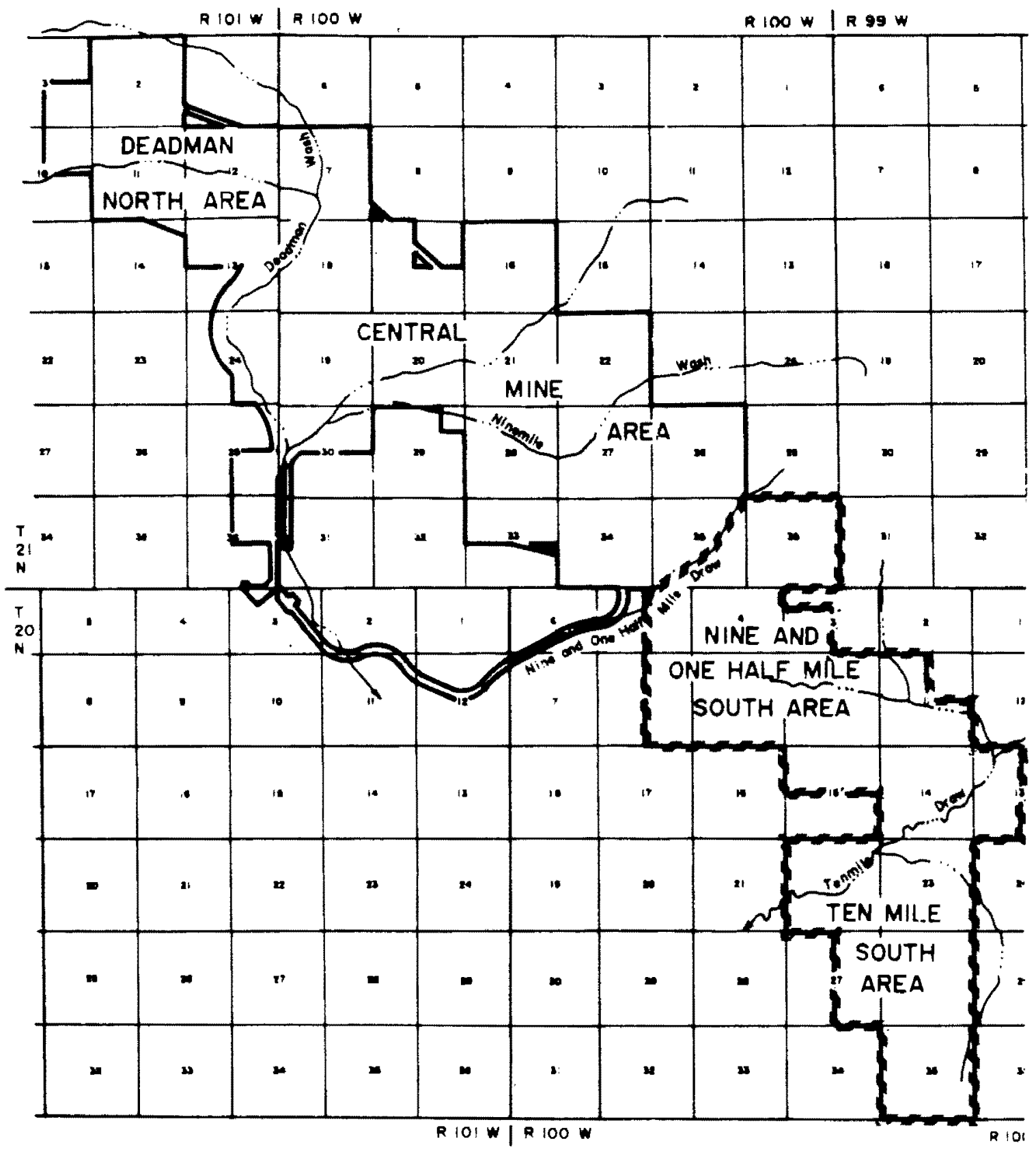

LEGEND

Permit Boundary

- Areo of Investigation

Figure 2. Jim Bridger mine areas. 


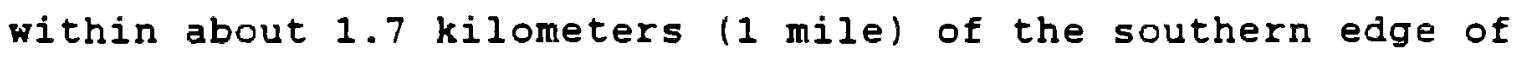
the study area. Access within the area is provided by a network of infrequently maintained dirt roads which provide good access during dry weather.

The primary center of commerce is Rock springs (population 19,458 in 1980), about 58 kilometers (35 miles) west. The climate of the region is arid to semiarid (Fisk, 1967) with annual amounts of precipitation in the 18 to 23 centimeter ( 7 to 9 inches) per year range (Root, Glass, and Lane, 1973). Topographic relief is moderate and ranges from 2042 to 2164 meters (6700 to 7100 feet) in elevation. Characteristics of the study area are steep slopes, hard rocks, cool climate, and sparse vegetation. Outcrops generally persist continuously for many kilometers, except for the area around Tenmile Draw.

\section{PREVIOUS INVESTIGATIONS}

The first recorded geological mapping in this region was provided by the Hayden survey during 1877. This part of Wyoming was divided into the Green River Division and the Sweetwater Division (Hayden, 1879), the axis of the Rock Springs Uplift serving as an approximate boundary between the two. Large areas of this part of Wyoming were investigated, with much emphasis being placed upon finding vertebrate fossils.

Many of the early geological explorations were spurred 
by the establishment of the transcontinental railroad rightof-way and, later, the search for coal to fuel the locomotives (Knight, 1955). Rich Tertiary mammalian and fish fossil discoveries also motivated vertebrate paleontologists to study parts of the Green River Basin in considerable detail. It wasn't until A.R. Schultz mapped the greater Rock Springs Uplift $(1909,1910)$ that accurate, detailed regional mapping took place, again motivated by the search for coal. A few years later, the Union Pacific Railroad right-of-way was mapped in detail (Lee, 1915). Afterward, significant contributions to the regional geology included the work of Schultz (1920), Sears and Bradley (1925), Nace (1936, 1939), Bradley (1945, 1961), Brown (1949, 1962), Fidlar (1950), Pipiringos (1955), Carey (1955), Ritzma (1955), Lewis (1961), Roehler (1961, 1965, 1979a, 1979b, 1979c), Fisk (1967), Oriel and Tracey (1970), Land (1972), Hendricks (1983), and Levey (1985). A number of University of Wyoming theses have also provided important information. Among the most important are Hale (1950), Swain (1957), Davis (1958), Johnston (1959), Mogensen (1959), Severn (1959), and Smithson (1959). Figure 3 outlines some of these study areas in relation to this investigation.

Fort Union sediments in the study area were at first placed within the wasatch Formation by Schultz (1909). It wasn't until much later that the Fort Union Formation was recognized as part of the Paleocene by R.W. Brown (1949) on 


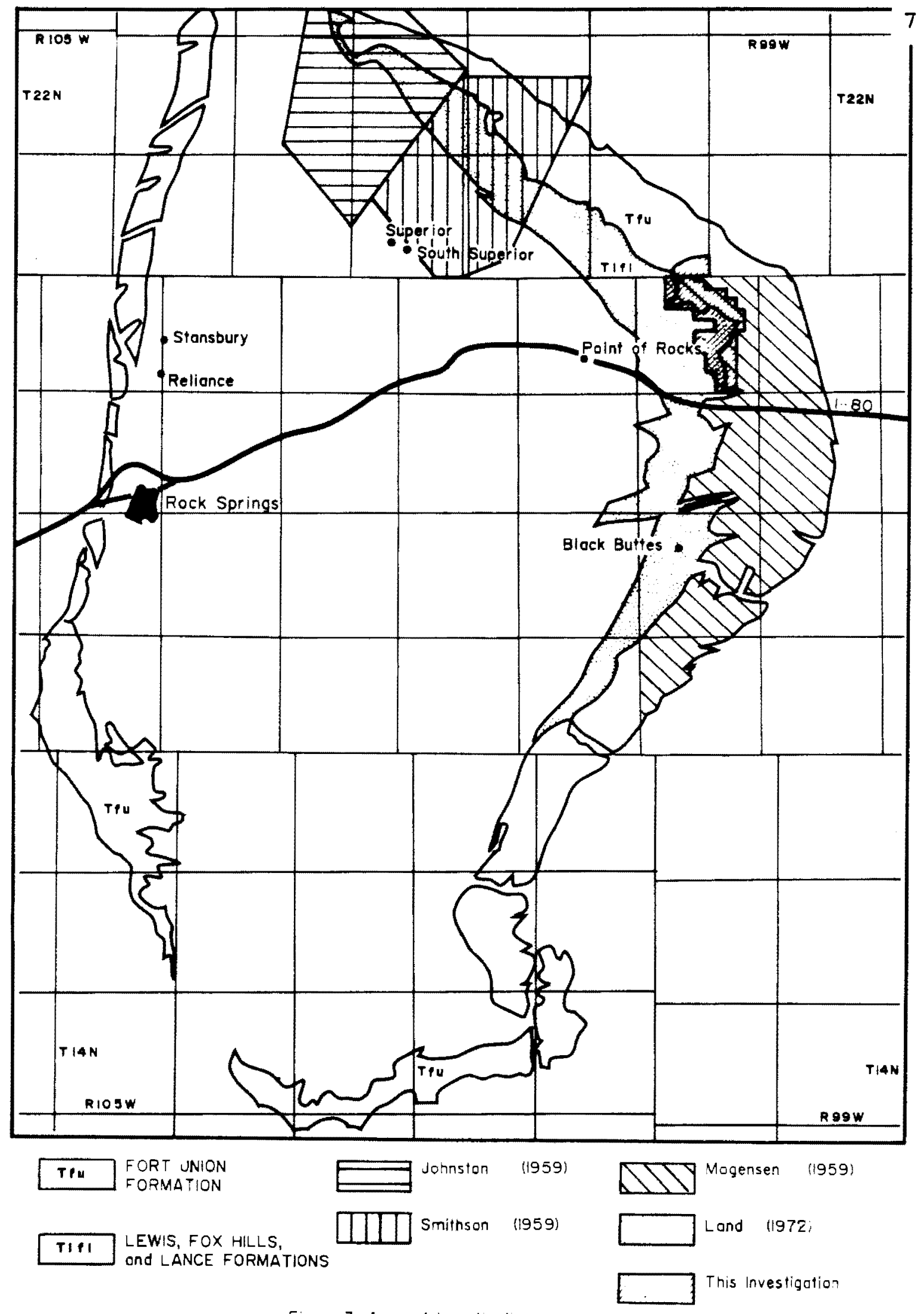

Figure 3. Areo of investigation 
the eastern margins of the Rock springs Uplift. Similarity of lithologies in the Upper Cretaceous through Eocene formations undoubtedly contributed to this problem.

Several published geologic maps by Welder and McGreevy (1966), Roehler (1977), Madden (1981), and Love and Christiansen (1985) are among those most helpful to this study.

\section{CURRENT COAL MINING OPERATIONS}

Coal mined at Bridger north of $91 / 2$ Mile Draw has been supplied almost exclusively to the nearby 2000 megawatt Jim Bridger Power Plant (Figure 4) since 1974. The power plant and mine offices are located about 13 kilometers 18 miles) north of Point of Rocks, Wyoming. Current annual production in the 6.4 to 7.2 million tons range is obtained from seams in the Deadman Coal zone of the Fort Union Formation, named in ascending order, the D1 through D5. The 10 meter (32 feet) thick Deadman 5-1 (abbreviated D51) seam in the Central Mine Area (Eigure 2) splits into two seams (D5 and D41) toward the northwest (Deadman North Area of Figure 2) and progressively into two (D54 and D31) and finally four (D5, D4, D3, and D21) seams toward the south and southeast (this investigation). The alpha-numeric naming convention of the Deadman seams was decided upon in the mid-1970's to facilitate computerization. Figure 5 is a cross-sectional representation of these seams through the Jim Bridger deposit. No faults have been found in the active mining area. 


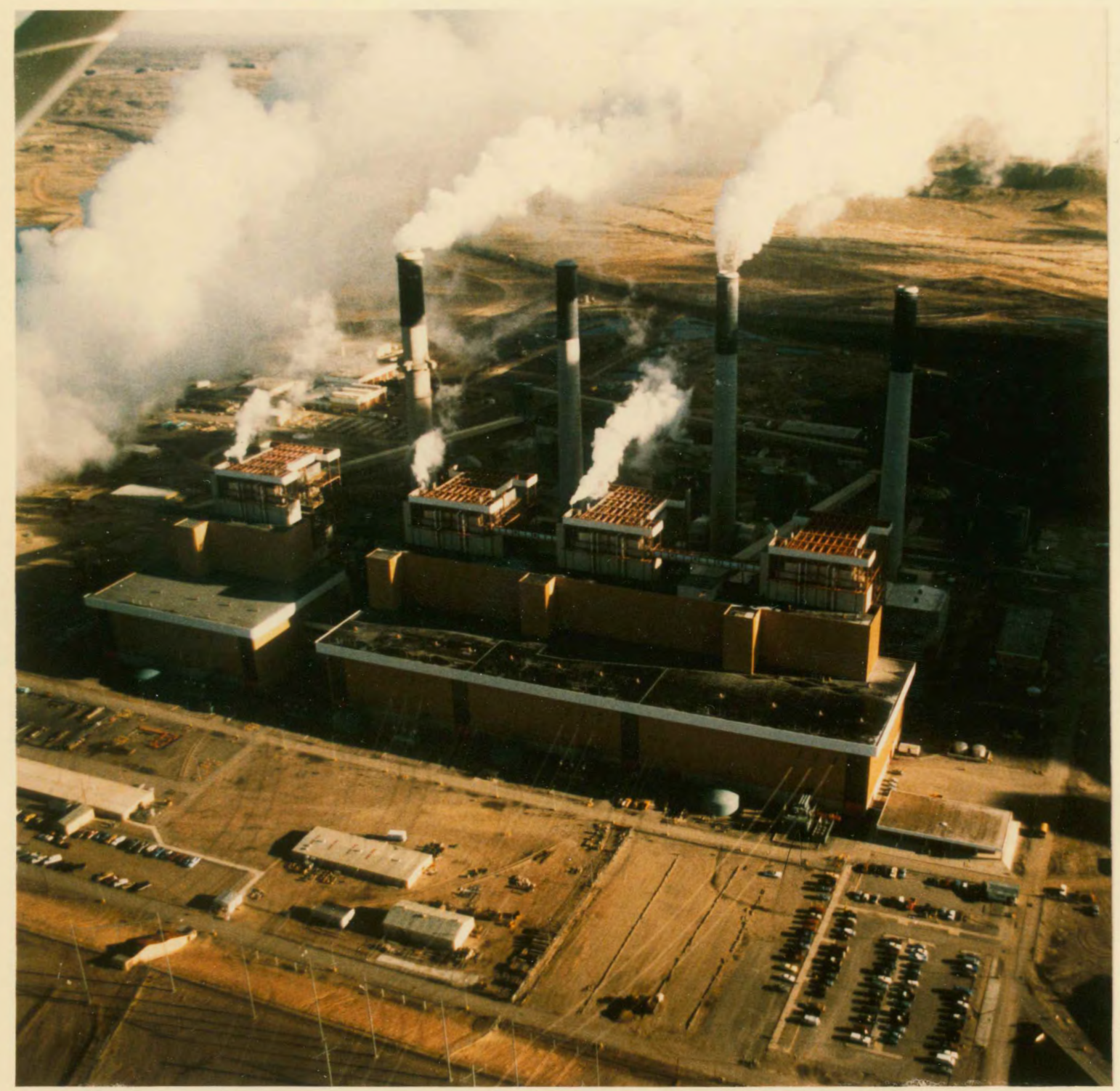

Figure 4. Jim Bridger power plant. 


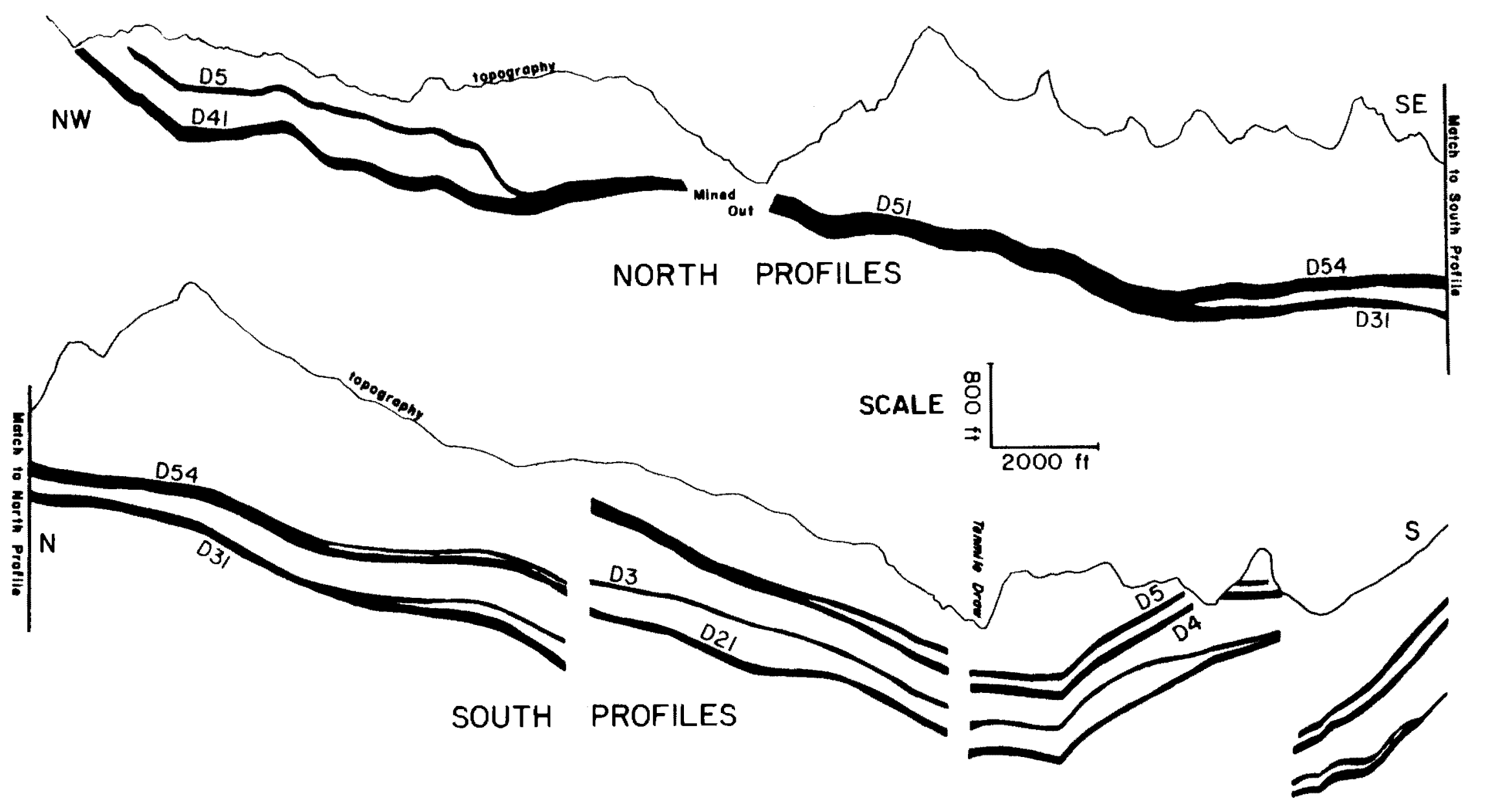

Figure 5. Generalized cross section of mineable seams, Jim Bridger Mine. These are reductions from computer output. Nine surfaces are plotted along the same profile line. Vertical exaggeration $16 \mathrm{x}$. 
Fort Union coal at the Black Butte Mine south of Interstate-80 has been under production since 1979 (L. Bongirno, project geologist, Black Butte Coal Co., 1987, pers. comm.). The Deadman seams at Bridger correlate well with the Little valley seams south of the Interstate (Nielsen, 1984). Black Butte Coal Co. is also mining coal from the Lance and Almond Formations. Prospect Point Coal Company operates a small surface mine near Bridger in the Almond Formation. The only other coal mine currently producing in the Rock Springs Uplift is the Swanson Mine, a small underground mine in the Rock springs Formation near Rock springs. Most of the mines in the superior and Rock Springs areas shut down as the railroad converted to more efficient diesel locomotives.

The mining process begins with the exploration phase. In assessing mineable coal reserve potential, boreholes provide by far the greatest source of data. There are over 1500 drill holes at the Jim Bridger field which provide detailed stratigraphic information. However, about 1000 of these holes have penetrated strata in active pit regions so the area south of $91 / 2$ Mile Draw has experienced much less drilling activity through 1986.

Because the coal seams dip gently to the east and northeast at one to four degrees, mining progresses in a series of pits more or less parallel to outcrop. Once mining of an area has begun, the excavations proceed downdip from 
the former outcrop in a long strip, thus the method is known as strip mining.

Following removal and stockpiling of topsoil (so it can later be reapplied to mined-out areas), the overburden is then drilled and the rock broken up with explosives. When appropriately deep cover is encountered, the overburden and/or parting material may be shot or blast-cast into the adjacent empty pit. The Bridger mine can thus be described as a modified open-cast strip operation. Fragmented overburden is removed with large 65 - to 75 -cubic yard capacity walking draglines (Figure 6) to expose coal. This is followed by the coal removal sequence where the material is drilled and blasted, then loaded into 120-ton belly dump haul trucks by 20-cubic yard capacity electric shovel, diesel backhoe or front-end-loader. Since the mine contains two seams in most active areas, this entire process (excluding topsoil removal and stockpiling) must be repeated.

\section{METHODS OF INVESTIGATION}

Existing color aerial photography was used to select the best localities for section measuring. Some preliminary geologic mapping was also done from these photos.

Dips are low, so Jacob's staff and Brunton methods are ideal for section measuring (Rottlowski, 1965). Where beds are thin, a measuring tape was used as an additional method. Particular attention has been paid to potential sedimentary 


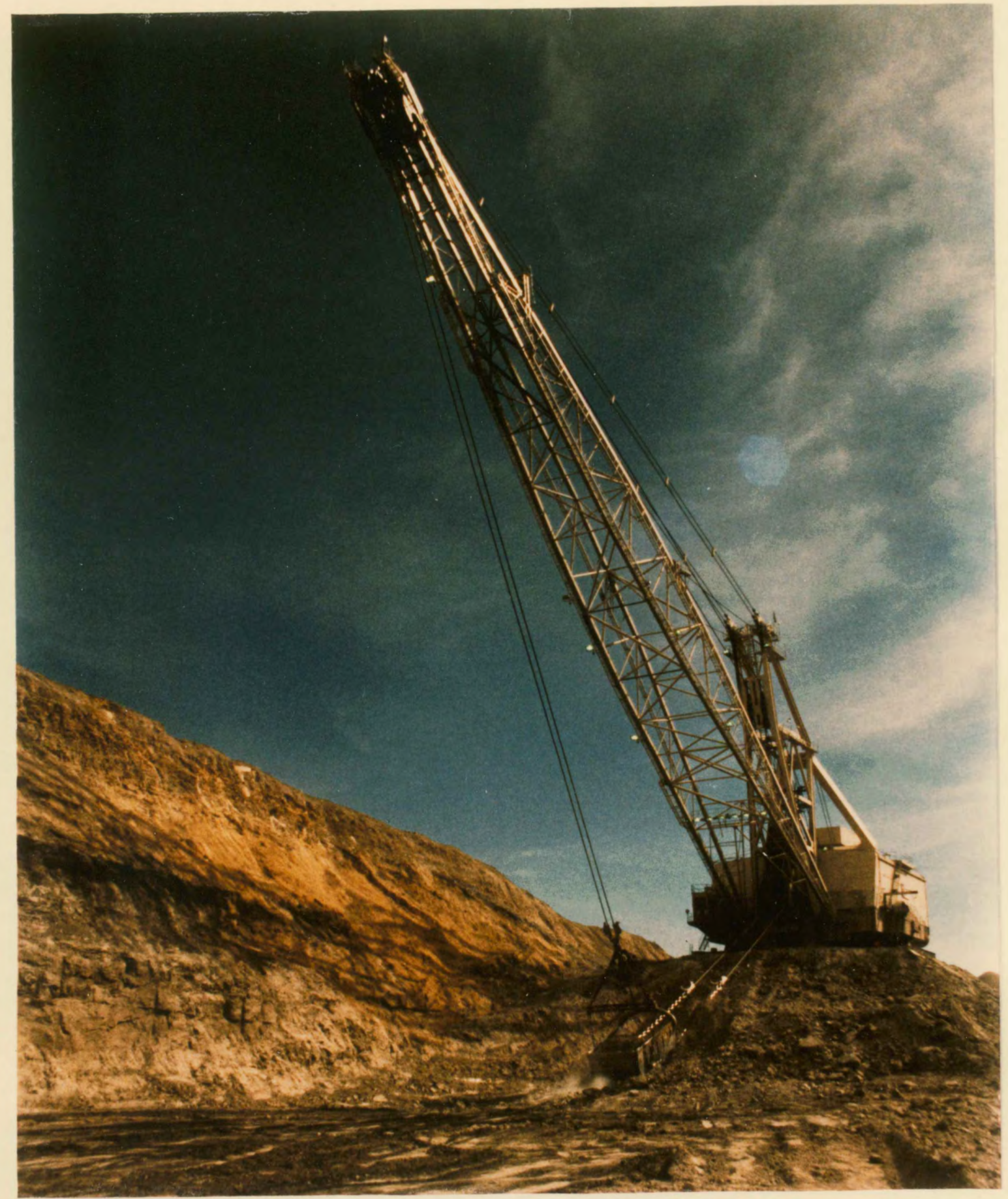

Figure 6. Large walking dragline exposing coal. The boom is 99 meters (325 feet) long. 
structures which can easily be overlooked in borehole logging. A drilling program was performed during July and August, 1986, which provided 72 additional stratigraphic columns. Eighteen paleocurrent measurements were also taken.

All measured section and borehole data was then coded and input into a computerized database. Geophysical log suites of gamma-gamma, high-resolution bed density, caliper, and microresistivity curves were used in conjunction with core photos and chemical analysis data for final interpretation.

After all borehole locations were plotted onto a base map, the geology was then interpreted and drafted onto the same base. This information included coal seam croplines, burn zones, and known or suspected faults. A fence diagram was constructed with computer assistance using measured section and carefully selected borehole data so as best to illustrate stratigraphic interrelationships. This fence diagram was produced as the base for the stratigraphic model. 
CHAPTER 2

REGIONAL GEOLOGY

TECTONIC SETTING

The Green River, Great Divide, and Washakie Basins are located in the Wyoming Basin physiographic province which consists of a series of broad structural and topographic basins (Hunt, 1967). These basins are partially filled with Tertiary deposits and are partially or completely separated by a number of uplifted structures. Basins are structural as well as topographic features. Regional tectonic relationships are illustrated in Figure 7 . The Uinta Mountains bound the Green River Basin on the south, while the Overthrust Belt associated with the Absaroka and Darby faults forms the western limit of the basin (Fidlar, 1950). Northern boundaries are formed by the en echelon ranges of the Wind River and Gros Ventre Mountains (Figure 7). The broad, anticlinal dome of the Rock Springs Uplift separates the Green River Basin from the Great Divide and Washakie Basins to the east.

The Rock Springs Uplift is a forty-mile long, doubly plunging, north-south-trending, asymmetrical anticline (Eardley, 1951). It is the largest uplift in the state which still retains its cover of sedimentary Cretaceous rocks (Blackstone, 1955). Other uplifts of comparable size 


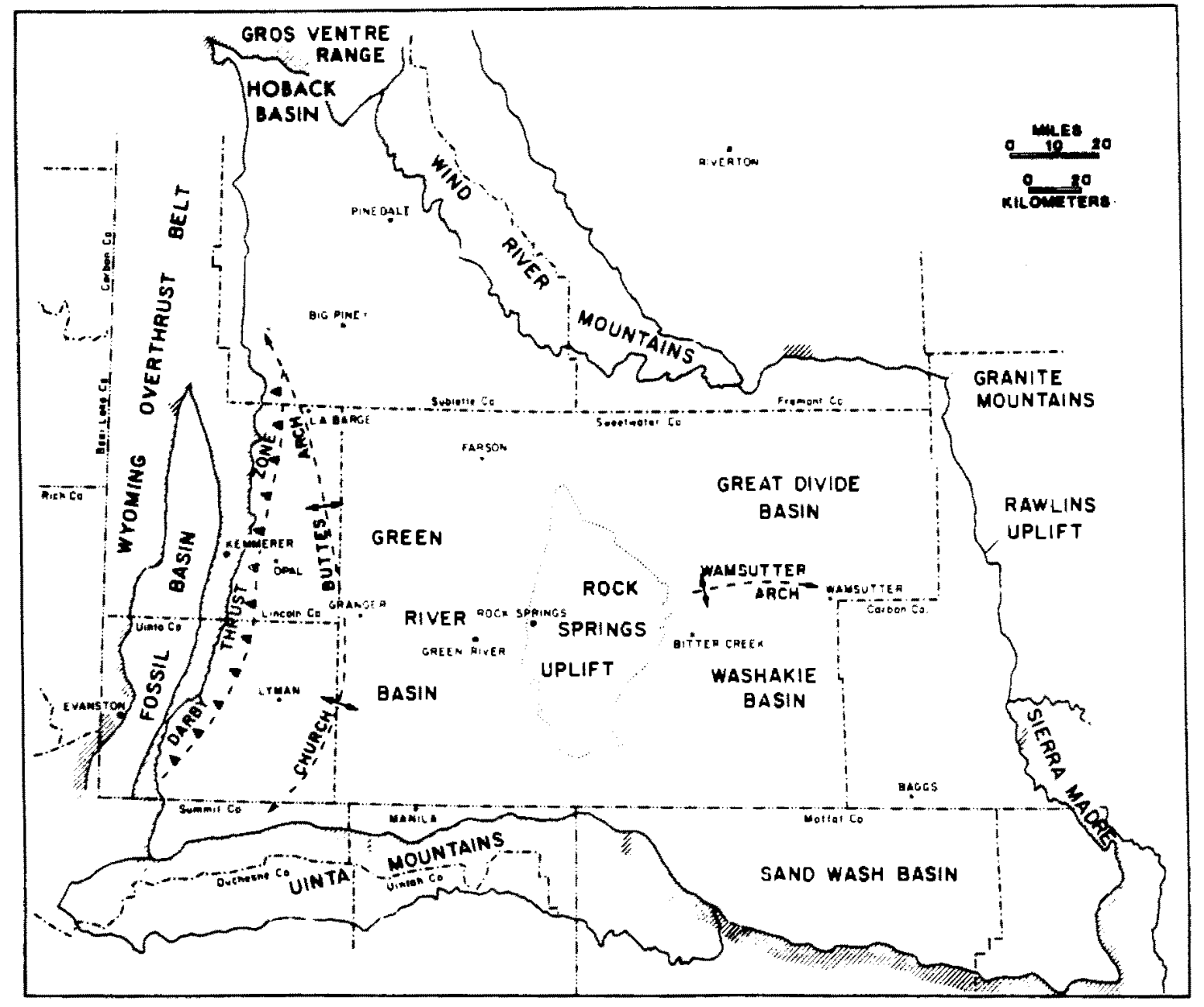

Figure 7 . Structural features of southwestern wyoming (after Sullivan, 1985). 
have been eroded deeply enough to expose a core of Paleozoic or Precambrian rocks. This fact is suggestive of a relatively late uplift. The broad arch of this feature has resulted in many resistant sandstone hogbacks on the west flank and cuestas on the east flank. Dips are fifteen to thirty degrees on the west side of the uplift, while five to ten degree dips are common on the eastern flank. Many eastwest-trending normal faults break up the continuity of outcrop relationships on both flanks of the uplift. Subsequent erosion of the region has exposed late Mesozoic and earlyto mid-Tertiary rocks. A geologic map of the Rock springs Uplift (Plate I) shows these features.

The Wamsutter Arch (Figure 7) is aligned with the greatest eastward bulging of the Rock Springs Uplift, and it has been postulated by Blackstone (1955) that the Arch is a direct continuation of the uplift. A WNW-ESE trending fault zone in the southernmost part of the uplift exhibits suspected reverse faulting, but this has not been demonstrated to any degree of certainty.

\section{REGIONAL STRATIGRAPHY}

Precambrian crystalline and pre-Baxter Shale (Late Cretaceous) rocks are not found at the surface in the vicinity of the Rock Springs Uplift. Pre-Baxter shale rocks are known from exposures in other areas of the state and in the Rock Springs Uplift area from electric well logs. 
Subjacent Units

Baxter Shale (Rba on Plate I). Erosion has exposed the Baxter Shale in the center of the Rock Springs Uplift. The Baxter shale, named by Schultz (1920), is composed of soft, homogeneous, bluish gray to drab, silty and gypsiferous, dark marine shales with thin beds of ripple-marked sandstone and concretionary beds of impure limestone and are 1020 to 1100 meters $(3350$ to 3600 feet) thick (Randall, 1961; Hale, 1955). The Baxter shale has been correlated by Hale with the steele shale south of Rawlins, with the Hilliard Shale at Church Buttes, and with the Mancos Shale of northwestern Colorado. An intricate intertonguing relationship exists with the overlying Blair and Rock Springs Formations.

Blair Formation (Rbl). Named by Schultz (1920) after a well-exposed sequence near Blair Ranch near Aspen Mountain on the eastern flank of the Uplift, the Blair consists of a 9.1 meter ( 30 foot) basal sandstone unit overlain by about 396 meters (1000 feet) of gray, silty shale with thin, interbedded ripple-marked sandstone (Randall, 1961).

Rock Springs Formation $(\mathrm{Kr})$. The prolific coal-bearing Rock Springs Formation was given formational status by Schultz (1920) and contains buff sandstone, carbonaceous shale, and bituminous coal beds. The aggregate thickness is about 512 meters (1680 feet) in the northern part of the uplift (Hale, 1955). Subsequent workers in this unit have de- 
scribed a series of sandstone and shale tongues (Reith, 1965; Roehler, 1965; Smith, 1965) that were later well correlated along the east and northeastern flanks of the uplift by Hendricks (1983).

Ericson Sandstone $(R e)$. The Ericson is composed of an interval of 130 to 207 meters (428 to 680 feet) of dominantly cliff-forming sandstones separated by a less resistant zone of thin-bedded, finer grained sandstone, carbonaceous shale, and ironstone concretions (Hale, 1950; 1955). Gill and Cobban (1966) proposed that up to 1097 meters 13600 feet) of strata may have been eroded prior to Ericson deposition but Law, Bucurel-White, and Bader (1983) suggest a conformable relationship with the Rock springs Formation. Miller (1977) reports that a widespread unconformity existed over much of the region at the end of Rock springs time, based on biostratigraphy.

Almond Formation (Ral). The coal-bearing Almond Formation, named by schultz (1920) after the excellent sequence of exposures near the historic Almond stagecoach station at Point of Rocks, contains 213 to 290 meters (700 to 950 feet) of carbonaceous shale, siltstone, mudstone, and sandstone alternating with coal beds of variable thickness and quality (Hale, 1950). The Almond Formation conformably overlies the Ericson Sandstone and is transitional with the Lewis Shale.

The Blair, Rock Springs, Ericson Sandstone, and Almond Formations comprise the Mesaverde Group in the Rock Springs 
Uplift area. The total thickness of all four units varies from 850 to 1555 meters (2800 to 5100 feet) (Randall, 1961). Lewis shale (Rle). The Lewis shale, named by Cross and spencer (1899), is a dark gray marine shale containing siltstone and sandstone beds in the upper portions of its 61 to 610 meter (200 to 2000 foot) thickness. Some interfingering of the Lewis with the underlying Almond Formation has been reported in the Red Desert Basin (Curry, 1969). Because of similar lithologies, the contact between the Lewis and the base of the overlying Fox Hills sandstone in the Rock Springs Uplift area has been difficult to distinguish in electric well logs. Good exposures are fairly rare. Fox Hills Sandstone (Kfh, Kfl). The Fox Hills Sandstone is composed of gray, ferruginous, and yellow sandstone and arenaceous clays over an 18 to 76 meter (60 to 250 foot) thickness (Land, 1972). There is considerable intertonguing with the underlying Lewis Shale but Land's interpretation of intertonguing relationships with the overlying Lance Formation has been challenged by H. Roehler (1987, mapping in prep.)

Lance Formation ( $R f l, R I)$. The latest Cretaceous Lance Formation varies from 0 to 230 meters ( 0 to 719 feet) in thickness and contains brackish and nonmarine shales, siltstones, coals, and lenticular sandstones that exhibit rapid horizontal and vertical facies changes (Land, 1972). Pre-Fort Union erosion has resulted in truncation of the 
Lance and Fox Hills at the northern and southern extremities of the uplift and from east to west across the Wamsutter Arch and Rock Springs Uplift. Roehler (1977) and Love and Christiansen (1985) map the Fort Union Formation atop Almond Formation beds on the western flank of the uplift, except for a very thin strip between Cedar Canyon and Nitch Creek (Plate I).

The uppermost Lance sandstone of Swain (1957) appears to be the same as the basal Fort Union sandstone of Mogensen (1959), but Severn (1959) has probably placed the Lance-Fort Union contact about sixteen meters higher stratigraphically. A distinctive coquinite bed has been found in upper lance sediments in the vicinity of South Table Mountain (Johnston, 1959). This bed is composed mostly of Ostrea glabra (?). Fort Union Formation (Tfu)

The Paleocene type Fort Union Formation is located near the mouth of the Yellowstone River, Buford, North Dakota (Meek and Hayden, 1862). Fort Union sediments on the east flank of the Rock Springs Uplift are similar; the differences are discussed in Chapter 6.

A thin conglomerate bed separates the Lance Formation from the Fort Union Formation on the west flank of the sierra Madre (Swain, 1957) but in the Rock Springs Uplift this layer is absent except for very localized occurrences. Instead, a fossil soil zone up to 1.8 meters ( 6 feet) thick separates the two formations (Land, 1972; Ritzma, 1965). 
Although not present in all localities, this paleosol is generally a good marker bed.

The Lower Paleocene Fort Union Formation consists of light gray to gray, buff, or tan sandstones, light to dark gray or greenish gray shales, siltstones, and claystones with coals, lignites, and carbonaceous shales and siltstones in the lower part of the formation (Mogensen, 1959). The thickness of the Fort Union sediments on the east flank of the Rock Springs Uplift is 183 to 437 meters (600 to 1435 feet).

Superjacent Units

Wasatch Formation (Twm). The Eocene Wasatch Formation was named by Hayden (1869) and consists of very fine grained to medium grained, lenticular sandstones, and mudstones and claystones with minor amounts of conglomerates, carbonaceous shales, lignites, and coals (Fisk, 1967). The Wasatch Formation is 305 to 914 meters (1000 to 3000 feet) thick.

Green River Formation (Tgl, Tgwt, Tgt, Tglu). The Green River Formation, also of Eocene age, is a discontinuous sequence of lacustrine and paludal deposits generally containing less conglomerate and coarse sandstone than the Wasatch Formation (Fisk, 1967). Its greatest thickness is attained west of Green River, where thinly-laminated chalky shale, buff-brown sandstone, algal limestones, and bedded trona accumulate to a thickness of greater than 470 meters $(1500+$ feet). East of the Rock Springs Uplift, the Green 
River Formation undergoes considerable intertonguing with the Wasatch Formation, reflecting changes in depositional environment over time.

Bishop Conglomerate (Tbi). The Oligocene Bishop Conglomerate contains clasts of red quartzite, gray chert, and limestone in a gray to white tuffaceous sandstone matrix (Love and Christiansen, 1985). It is variable in thickness and present in the southwestern part of the Rock Springs Uplift.

Miocene Rocks Undiff. (Tm). A pale green to tan tuffaceous sandstone and claystone unit of Miocene (?) age with a local basal conglomerate of uncertain correlation is present on the southwestern, central part of the Uplift. This unnamed formation may be related to other large areas of somewhat poorly studied Miocene rocks near the south end of the Wind River Range. Kirschbaum (1985) has mapped some of these deposits as part of the Bishop Conglomerate.

Figure 8 is a composite erosional columnar section showing each of the above units.

\section{GEOLOGIC HISTORY}

The Archaeozoic was a time of igneous activity and sedimentation. The Wyoming region had already established its foreland nature during precambrian time. This status remained unchanged throughout the Paleozoic and Mesozoic. The Cordilleran trough was present to the west, while the 


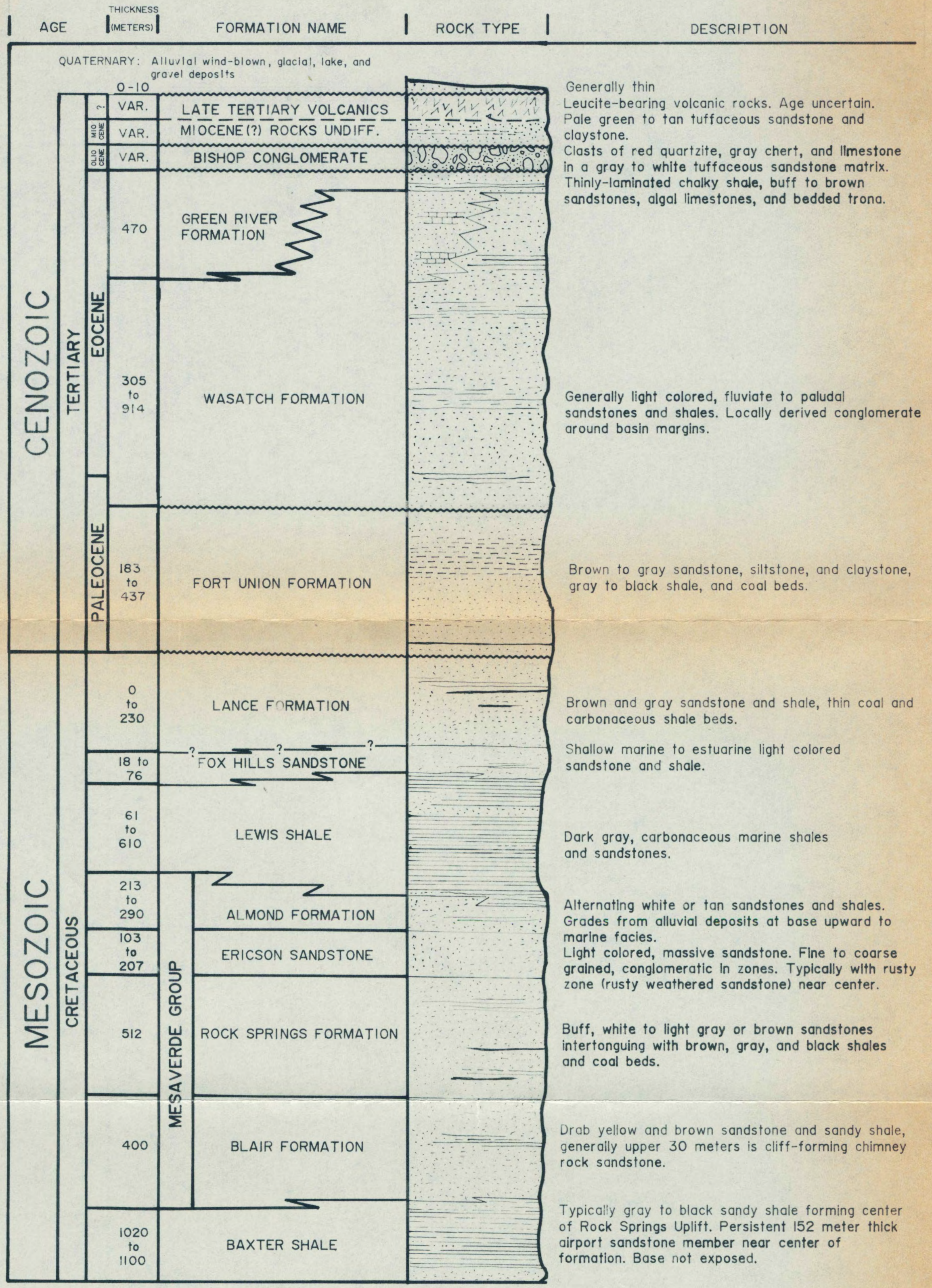

Figure 8. Composite Erosional Columnar Section

Rock Springs Uplift

Sweetwater County, Wyoming

Modified after Root, Glass, and Lane (1973)

and Love and Christiansen (1985) 
Front Range Highland stood to the south affecting sedimentation during the Paleozoic and Mesozoic (Lovering, 1929).

Repeated transgressions of the ancient seas that spread eastward from the Cordilleran trough characterized Paleozoic sedimentation. Regressions and erosional cycles occurred often without significant deformation.

Terrestrial deposition occurred during Triassic and Early Jurassic periods. Two major transgressions of the sea were followed by additional terrestrial sedimentation and finally by erosion during the Late Jurassic.

Seas once again transgressed into the region in the Early Cretaceous, depositing shales and sandstones. During Middle and Late Cretaceous time, sedimentation was significantly affected by the Nevadan Orogeny. Newly formed basins became depocenters of vast amounts of sediment as there were many transgressions and regressions during this time (Roehler, 1965). Prominent shoreline fluctuations were superposed upon these thick sandstone-shale-minor limestone sequences. The Late cretaceous geosyncline extended from what is now Utah to the Mississippi River and from the Gulf of Mexico to the Arctic ocean. Deposition in this area amounted to 3050 meters $(10,000$ feet $)$ or more.

The Baxter Shale was deposited during an extended transgression of a Late cretaceous sea. The alternatingtransitional sediments of the Mesaverde Group, including wave-dominated deltaic deposits of the Rock springs Forma- 
tion were a result of gradual eastward regression (Levey, 19851 .

Marine shales and thin, interbedded sandstones of the Lewis shale were produced during a final advance of the Late Cretaceous sea and its lingering withdrawal. The final retreat of the sea was marked by deposition of the Fox Hills Sandstone, a sequence of sandstone and siltstone deposited along a barrier island coastline in littoral, shallow neritic, and estuarine environments (Land, 1972).

Terrestrial deposition commenced at the close of the Cretaceous with the transitional Lance Formation and continued during the general uplifting of the Laramide orogeny. The Wind River Mountains and Rock Springs Uplift began to become active at this time (Roehler, 1961). The Uinta Mountains may have also begun to rise during the latest cretaceous (Picard, Bruhn, and Beck, 1983). A temperate to subtropical climate was in effect during Lance time (Dorf, 1938). Pre-Fort Union erosion and uplift was followed by a brief period of reduced sedimentation, permitting floral development.

Paleocene and Early Eocene deposition occurred almost continuously under a warm, moist climate. Reworked detrital materials became a larger percentage of sediments as major source areas in the Uinta Mountains, the Park Range (Front Range Highland), and the Rock Springs Uplift (Beaumont, 1979) were developed. Paleocene (Fort Union) and Eocene 
(Wasatch) sediments were deposited over older rocks nearly simultaneously with uplift resulting in unconformable relationships near these structures.

The Green River, Great Divide, and Washakie Basins were all interconnected during the time of Eocene sedimentation and large lakes (Lake Gosiute, Lake Uinta) were a result of uplifting of the Uinta Range and downwarping of the basins (Oriel and Tracey, 1970). The Rock Springs Uplift was not an influential structure at this time. Lacustrine beds of the Green River Formation were thus able to interfinger with the fluviatile and paludal deposits of the Wasatch Formation. Coarse-grained fluvial sediments of the Bridger Formation, now found only over the Green River Formation, followed those of the Wasatch as climatic changes and renewed uplift signaled the demise of the lake by midEocene time. The Rock springs Uplift began separating the Green River Basin from the Great Divide and Washakie Basins. Large areas were covered with Oligocene Bishop Conglomerates but much of these sediments were subsequently eroded after a period of mild uplift during Late oligocene or early Miocene time.

The Miocene was an epoch of accentuated uplift and deposition of coarse, sedimentary debris distributed around the principal uplifts. Similar deposition occurred during the Pliocene after an erosional interval. Post-Miocene normal faulting and subsidence took place as the entire Rocky 
Mountain region was uplifted. The only other post-Wasatch sediments found around the Rock Springs Uplift are quaternary lake, alluvial, and loessian deposits.

A final post-Pliocene regional uplift was followed on the northeast flank of the Rock Springs Uplift by the volcanism of the Leucite Hills. These are remnants of cinder cones and lava sheets that cap hills of Upper Cretaceous through Eocene sedimentary rocks (Carey, 1955). Although presumed to be young, the age of this volcanism has not been adequately determined (Johnston, 1959; Smithson, 1959), but can be no older than mid-Eocene, since many of these features rest upon Green River Formation beds. 
CHAPTER 3

DATA COLLECTION

Field work was undertaken during the summer months of 1986. This work consisted of mapping surface outcrops, measuring sections and drilling to obtain subsurface data downdip. Twenty-nine measured sections were obtained along outcrop. Seventy-two rotary boreholes were drilled in the area of investigation to determine coal seam correlations, coal quality characteristics, parting line geometries, structure and stratigraphy, coal subcrop/oxidation limits, and potential subsurface burn zones. Surface section data is presented in Appendix 1 and subsurface section data used in generating the panel diagram is found in Appendix 2.

\section{AIRPHOTO INTERPRETATION}

Prior to field work, $9 \times 9$ aerial color orthophotos were studied to determine areas of surface burn (clinker) and areas of sufficient surface relief to provide characteristics of a good measured section. These photos were taken during the summer of 1978 as part of a mine-wide vegetation survey .

Locations of coal outcrops were noted where present, but generally these were not discernable from aerial photos. This detail was transferred and sketched onto 1 inch to 800 
feet scale topographic maps for use in the field. Refinements and adjustments to these maps were made as the area was traversed and sections measured.

\section{MEASURED SURFACE SECTIONS}

Twenty-nine surface sections were measured in the study area. These sections traversed known or suspected coal outcrops. Emphasis was placed on the coal-bearing lower part of the Fort Union and uppermost Lance Formations. All sections measured strata above and below coal seams.

The Fort Union and Lance Formations form a series of low cuestas in this area (Figure 9). West and southwest facing slopes are generally steep, while the northeast and eastern slopes are gentle. Outcrops generally strike between $\mathrm{N} 75 \mathrm{~W}$ and $\mathrm{N} 10 \mathrm{E}$ with associated dips between one and four degrees north to east-northeast.

Measured section locations were plotted as accurately as possible on field topographic maps. Where locations were still somewhat uncertain, some sections were surveyed for more exact locations.

Jacob's staff and Brunton compass methods were used (Figure 10) in section measuring, since dips are generally slight. Kottlowski's (1965) technique was used for each section.

Where thin beds were encountered, a measuring tape was used to determine more accurate bed thickness. Careful mea- 


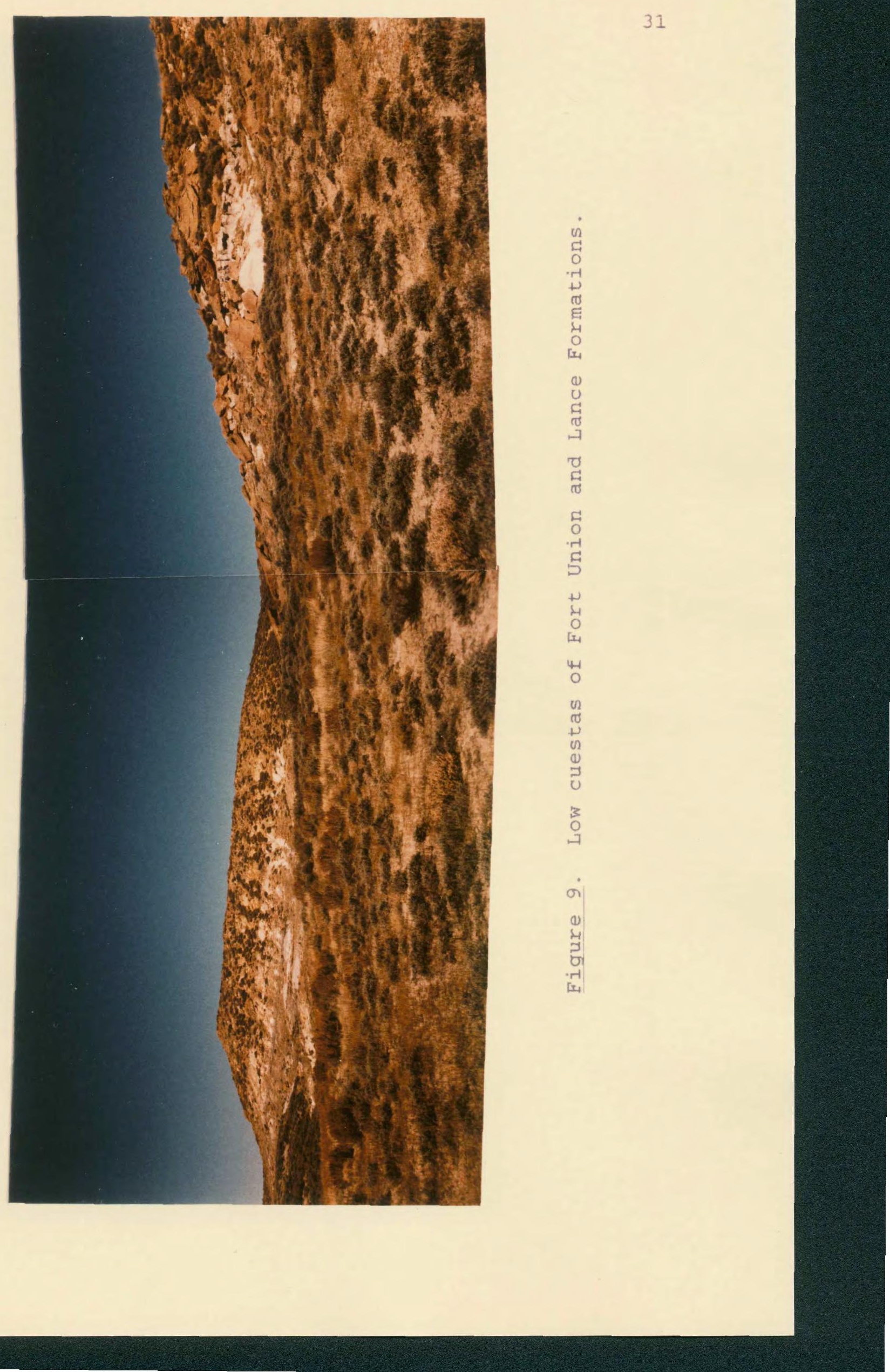




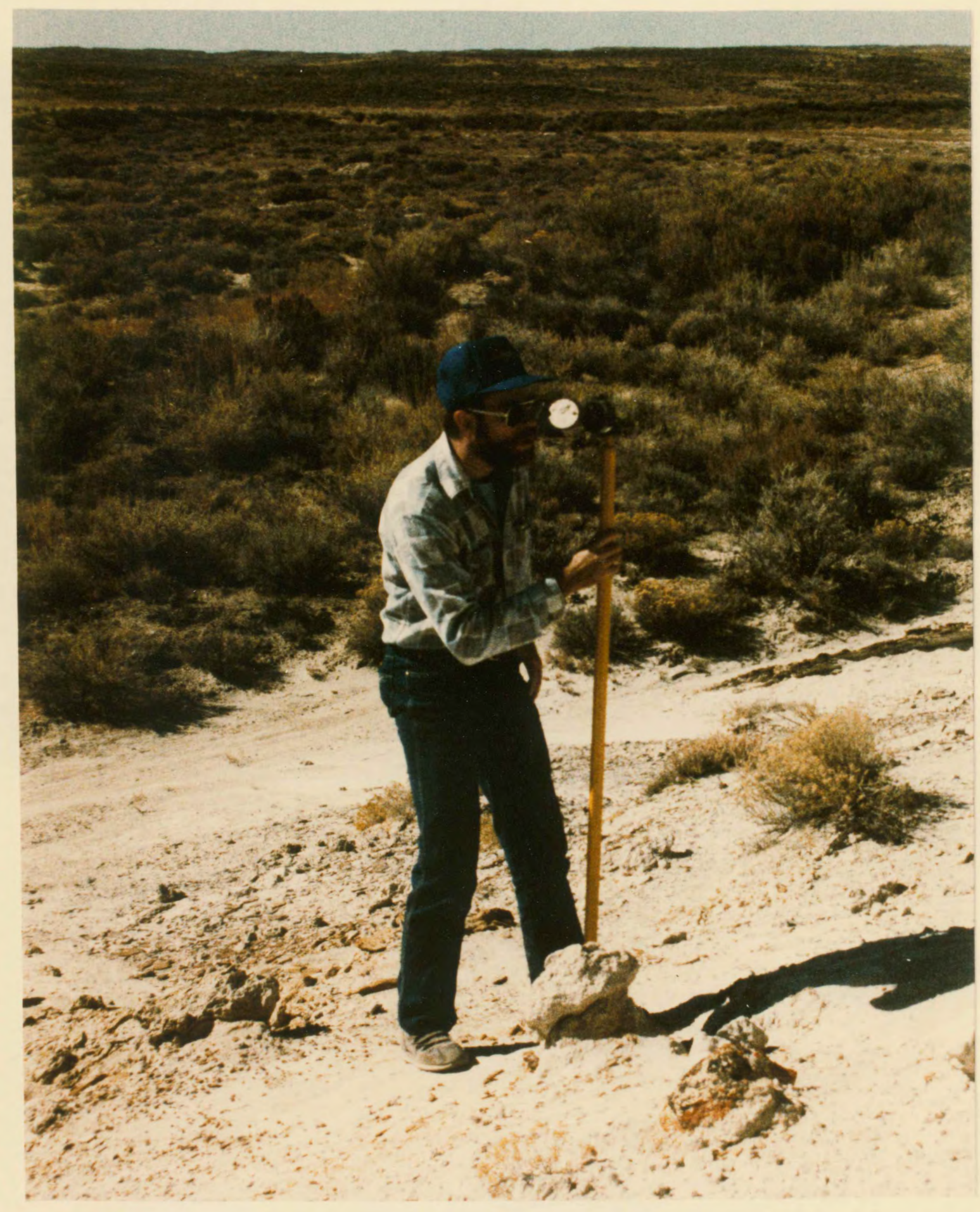

Figure 10. Section measuring with Brunton and Jacob's staff. 
surement was necessary because of the effects of erosion and downslope slumping.

\section{SUBSURFACE SECTIONS}

Transportable, truck-mounted rotary drilling rigs are vital in the acquisition of exploration and development data (Figure 11). These data can be in the form of rotary or continuous core holes.

\section{Exploration and Development Rotary Holes}

Exploration and development rotary holes provide by far the greatest single source of data for assessing mineable coal reserve potential. A total of 581 test borings of shallow depth (less than 200 meters) have penetrated the Fort Union Formation in the study area. Some of these were drilled prior to 1978 and had inadequate or no geophysical logs. Most of the attention of drillsite geologists of the past has been directed to how thick and how deep the coal seams are. More recently (since about 1981), attention has also focussed on lithology, groundwater, sedimentary structure in core holes, and coal quality. The technology of geophysical logging tools has progressed, also providing further refinement of subsurface information.

From a coal exploration and development standpoint, the most useful product of a rotary borehole is the geophysical log suite. The natural gamma or gamma-gamma, high-resolution bed density, caliper, and single point or microre- 


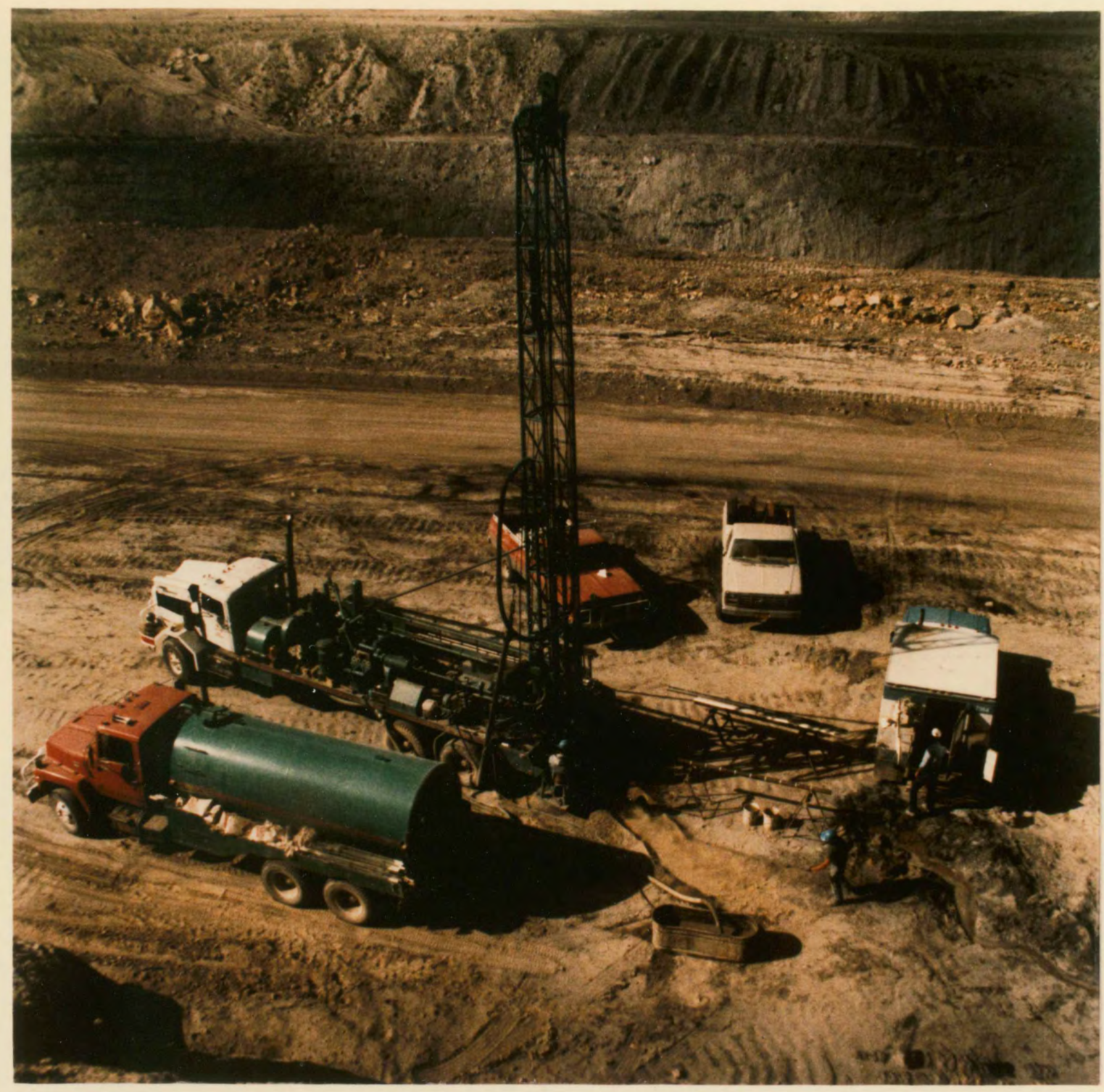

Figure 11. Transportable rotary drilling rig used to make exploration boreholes. Note core stands at rear of drilling rig and geophysical logging truck at right. 
sistivity curves provide precise definitions of coal bed stratigraphy. Top and bottom contacts can be defined to within 0.03 meter (.1 foot) accuracy. A gamma log can be used as a relative grain-size indicator for sandstone, siltstone, and claystone interpretation. Figure 12 illustrates how a geophysical log suite is used in lithologic determinations.

Chip samples are collected at five-foot intervals as the hole is drilled. Frequently, however, these samples are contaminated by rock chips from upper strata and mingle with chips from the rock layer being drilled. Hence, the geophysical log (specifically, gamma and density) must be consulted for accurately determining the true lithology. At other times, circulation (air or air and water) may be lost causing "no returns" as returning chips become lost in subsurface voids.

Rotary chips are also poor indicators when it comes to defining sedimentary structures. Sometimes it is possible to discern cross-bedding in larger chips, but this is not usually the case. Chip samples are usually not retained or analyzed. Lithologic logs are kept for rotary boreholes (in case of a caving hole which cannot be probed by the logging unit), but these record gross lithologies, when chip samples are present.

Continuous Core Holes

Continuous overburden core holes are cored from the 

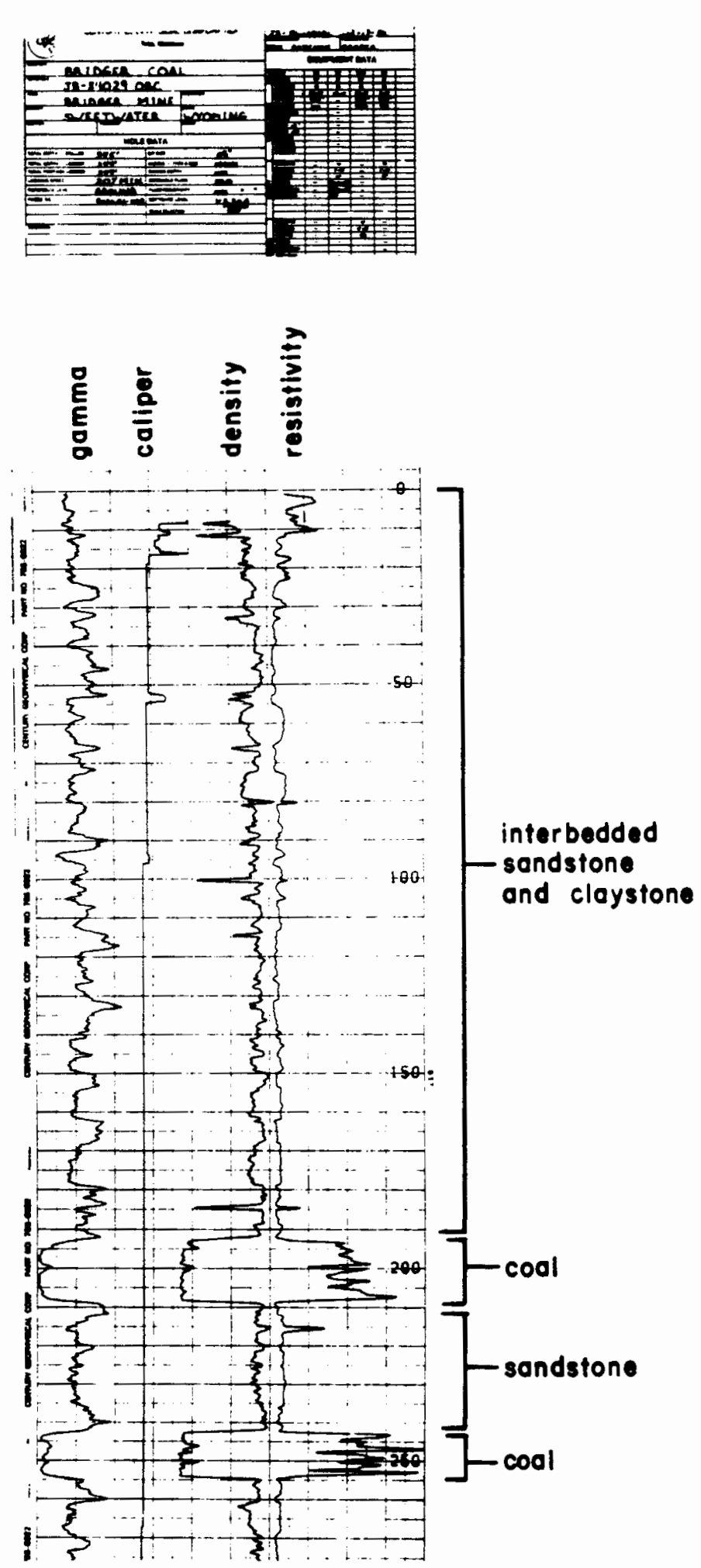

Figure 12. Geophysical log suite. 
surface to below the last mineable coal seam and are performed in response to the permitting process. These core holes were completed for the study area in 1985 with a spacing of roughly one hole for every 160 acres.

In addition to the same suite of geophysical logs run for rotary boreholes, detailed lithologic logs are recorded for each core interval according to guidelines proposed by McPhater and MacTiernan (1983) and later tailored for corporate purposes. The core is then bagged and packaged for shipment to the laboratory for analysis. Core recovery is generally very good (greater than 95\%), allowing documentation of detailed sedimentary structures, gradational lithologies, grain size and sorting, and other features (i.e., clasts) as well.

The core is photographed at the laboratory before any such analysis is performed. Although Figure 13 is an example of such a photograph, it represents but a small interval of a particular borehole. A continuous core hole may require up to forty or more boxes (photographs) to portray the entire subsurface section.

Exhaustive coal and rock chemistry data, performed under the scs classification for technical rock types, is produced in addition to the photographs (C. Bowen, geologist, Glenrock Coal Co., pers. comm.). These photos and textural data are then compared to lithologic and geophysical logs for conflict resolution regarding lithology. 


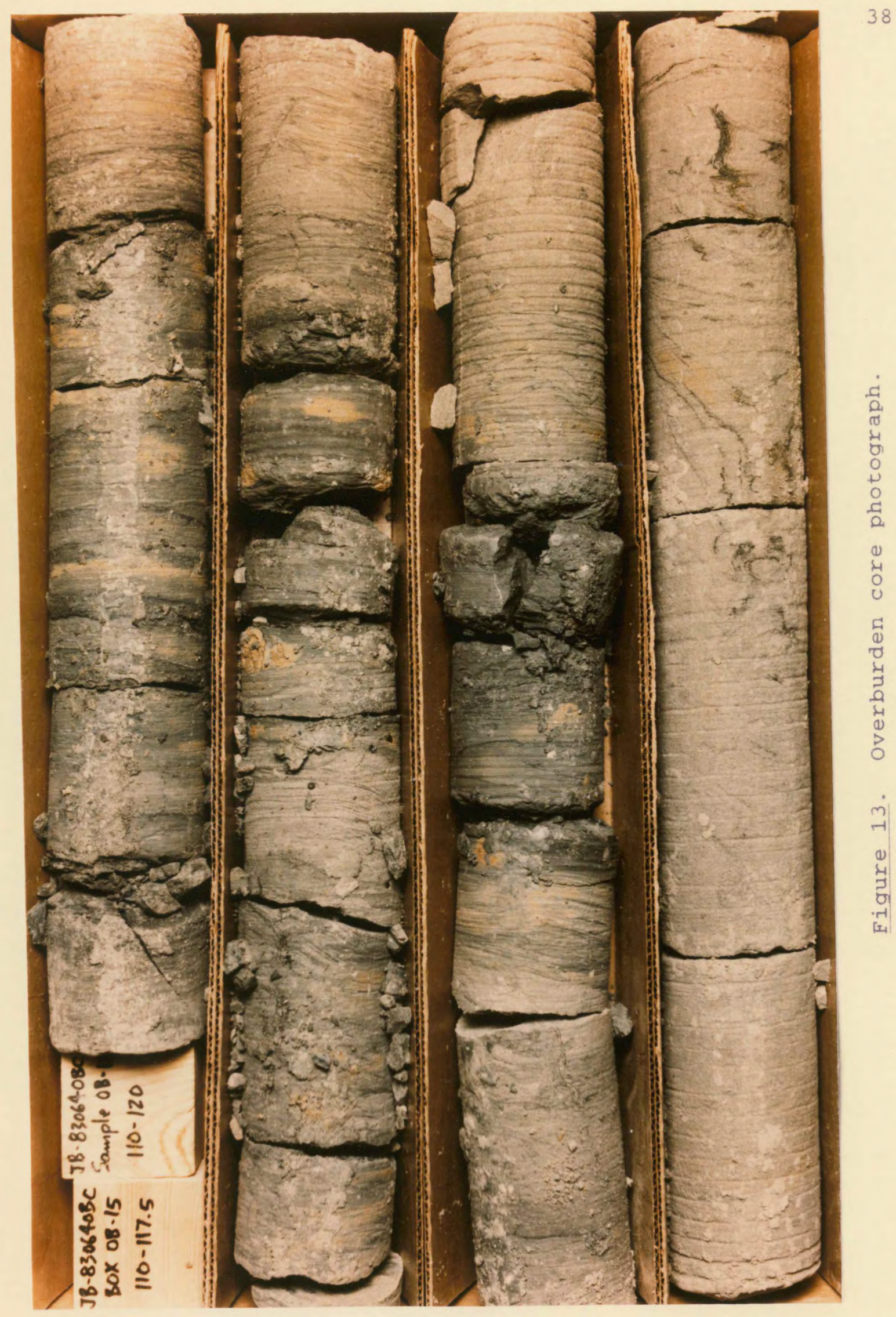


Continuous core holes provide the foundation of the stratigraphic model, with the addition of carefully selected rotary boreholes where required.

\section{PALEOCURRENT MEASUREMENTS}

Eighteen paleocurrent measurements were taken in the northwest portion of the study area where a trough crossbedded sandstone unit in the overburden was particularly well exposed. Paleocurrent directions were measured with a Brunton compass according to the techniques suggested by Compton (1962). This data is presented in Appendix 3. 


\section{CHAPTER 4}

\section{ANALYTICAL PROCEDURES}

Several geological computer programs were utilized in this study. However, in order to use these programs it was necessary to establish IBM-3091 mainframe-resident databases for all field data. This included but was not limited to: digitized outcroplines, burnlines, faults, parting lines, and surveyed locations of measured sections and boreholes, as well as all lithologic information. Extract software was utilized to produce data files in formats acceptable to applications software.

\section{CODING OF LITHOLOGIC DATA}

The purpose of the coding process was to transfer all data from field book to computer where it could be manipulated for graphic output. In so doing, field descriptions were checked for uniformity, proper color chart names, and other parameters before input. Measured surface and representative subsurface sections are compiled in Appendices 1 and 2 , respectively.

The three-digit code in the far right column of these printouts is a graphic chart code, simplified from a methodology proposed by Ferm and Berger (1979) to reduce lithologic intervals for each borehole or measured section to a miniature stratigraphic column at any desired scale. 
Lithologic types have been limited to the following:

$\begin{array}{ll}\begin{array}{c}\text { first } \\ \text { digit }\end{array} & \text { rock type } \\ 1 & \text { coal } \\ 2 & \text { shale } \\ 3 & \text { claystone } \\ 4 & \text { siltstone } \\ 5 & \text { sandstone } \\ 6 & \text { conglomerate } \\ 7 & \begin{array}{l}\text { limestone } \\ 8\end{array} \\ 9 & \begin{array}{l}\text { surficial deposit } \\ \text { thermally altered unit }\end{array} \\ 0 & \text { other clinker) }\end{array}$

graphic output

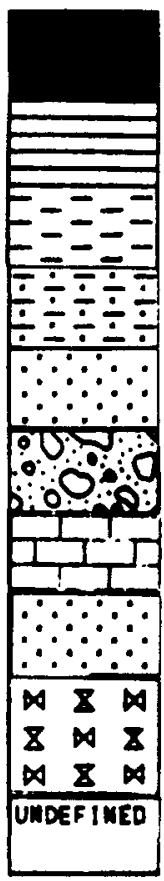

These choices were selected by geologists working in 1980 for the Technical Services Division of NERCO, Inc., Portland, Oregon, as most representative of coal-bearing sequences of the Wasatch and Fort Union Formations in Wyoming and Montana.

\section{GRAPHIC LOGS}

Graphic log plotting software (LOGPLOT) has been used to produce hardcopy stratigraphic column output (Figure 14). These columns can then be used in coal seam correlation, cross section, or panel diagram applications. This software was intended primarily for borehole examination and correlations. 


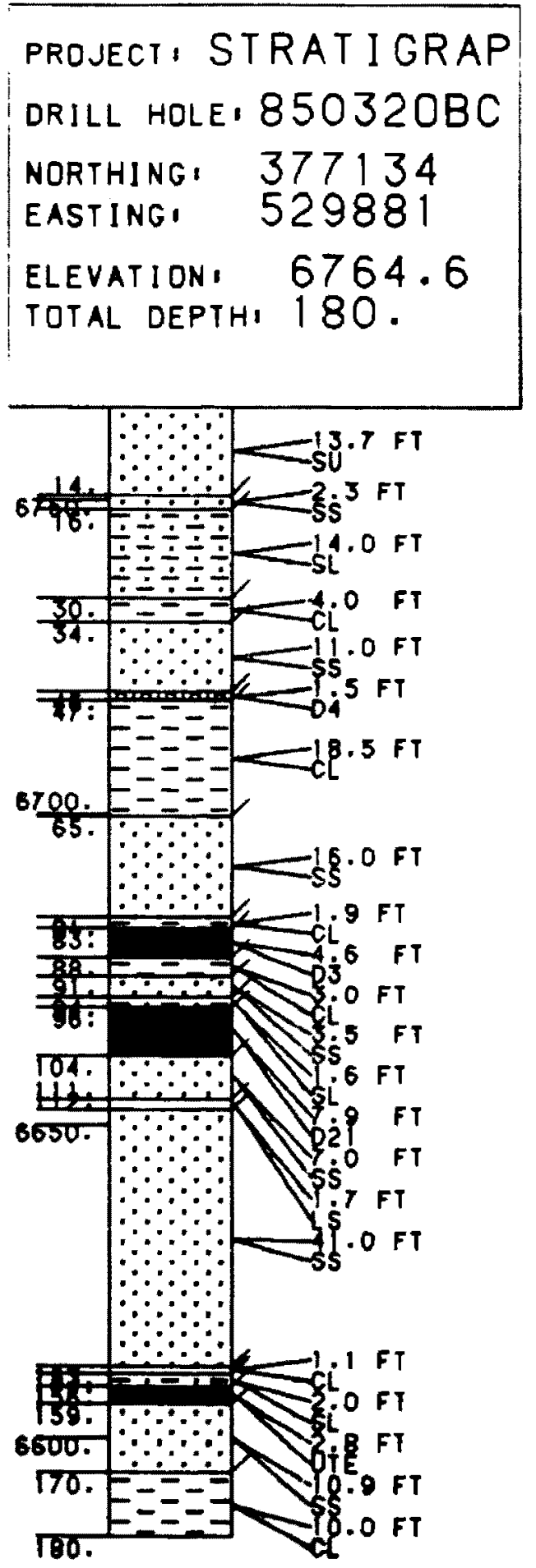

Figure 14. Graphic log plot. 
COAL SEAM CORRELATIONS

In some parts of the study area, coal seam correlations are fairly well known, particularly where drilling density is relatively high. However, after the two thick coal seams ( $D 54$ and $D 31$ ) begin to split, correlations are less certain in a few localities. Furthermore, coal beds in the upper Lance Formation begin to become noticeable on outcrop in the southern portion of the study area. Sometimes the geologist is unsure of the precise seam nomenclature in a particular measured section or borehole.

To aid in the process of coal seam correlation, a sophisticated, menu-driven computer software package called STRATVIEW was developed by ZYCOR, Inc. STRATVIEW will correlate matched seams along a user-selected baseline or between specific boreholes. However, lithologic units other than coal seams are not correlated by the program.

STRATVIEW will adjust each borehole for surface elevation and scaled distance between holes. Figure 15 is an example of such output. Further refinements of this software have permitted graphics plotting capabilities similar to those of LOGPLOT, providing lithologies of each stratigraphic interval. STRATVIEW is particularly well suited to quick definitions of fault and parting line locations along a given baseline. Other options include the capability to add geophysical logs at the same scale for each hole. 

PREPARATION OF CROSS-SECTIONS

Representative dip cross-sections were constructed with the aid of STRATVIEW using measured sections and boreholes approximately every 150 meters along the length of the study area. Four cross-sections along strike were constructed for the study area. A few smaller, localized areas required additional cross-sections to determine existence of fauls, coal seam correlation questions, local seam washouts or erosion zones, and other problems. Oxidized and burned zones were commonly encountered along outcrop (Plate II), and STRATVIEW was useful to a degree in resolving some of these problem areas.

A final set of cross-sections was designated as the base for the fence diagram. This series was planned to maximize use of the continuous core holes and to optimize the graphic display. Lithologies of measured sections and additional boreholes were added with LOGPLOT. Facies interpretations between each stratigraphic column were added later and the final drafted version was used as an overlay with screened (faded) topography to produce Plates IIIA through IIIC. 


\section{CHAPTER 5}

\section{STRATIGRAPHIC MODEL}

A model can be defined as a facsimile in three dimensions or a reproduction in miniature (Thrush, 1968) of a mine, deposit, or other geological phenomenon. Thus, a stratigraphic model can be defined as a three-dimensional miniature of the stratigraphy of a particular area or region. The model can include lithostratigraphic and chronostratigraphic units.

stratigraphic modeling was pioneered in the Gulf of Mexico primarily for formational analysis in the exploration of oil and gas (Frink, Wittick, and Dedman, 1977). Dedman, Lindsey, and Schramm (1975) and Neidell (1980) applied stratigraphic modeling to seismic processing in a variety of subsurface applications.

Although primarily geared to interpretation between well logs and seismic geophysics, the basic principles may be applied equally to situations in the mining industry, where shallow borehole geophysics and measured surface sections are commonly encountered in evaluation of stratabound deposits, especially coal and uranium. This study will address lithostratigraphic and chronostratigraphic units in the southern portion of the Jim Bridger coal field. 


\section{LITHOSTRATIGRAPHIC SUMMARY}

The lowermost portion of the Fort Union Formation in the area of investigation consists of the following lithologies in decreasing order of abundance: sandstone $160.3 \%$, claystone (16.6\%), siltstone (10.7\%), coal (9.5\%), surficial unit (2.6\%), limestone (2.4\%), and shale (0.04\%). Conglomerate, ironstone, and clinker are found in very small quantities. The percentages are based on 1,977 meters 16,487 feet) of representative core drilling (Appendix 2). The total stratigraphic thickness under consideration represents up to about half of the Fort Union Formation and approximately the top ten percent of the Lance Formation.

\section{Lithology and Facies Patterns}

The sandstones typically are subarkosic, very fine- to medium-grained, light brownish gray to light yellow brown in surface sections or light olive gray to bluish gray in subsurface (unweathered) sections. Sandstones in surface sections fall generally into one of three types:

I. relatively poorly cemented, light brownish gray, generally structureless, erodes to sloping surfaces.

II. clay cemented, very light gray to white, trough- to planar-cross bedded, typcially micaceous, erodes to ledges or slopes.

III. calcite cemented, light reddish brown to orange brown, contorted or trough-cross bedded with or without siderite bands, erodes to ledge.

Types I and III sandstones are illustrated in Figure 16. 


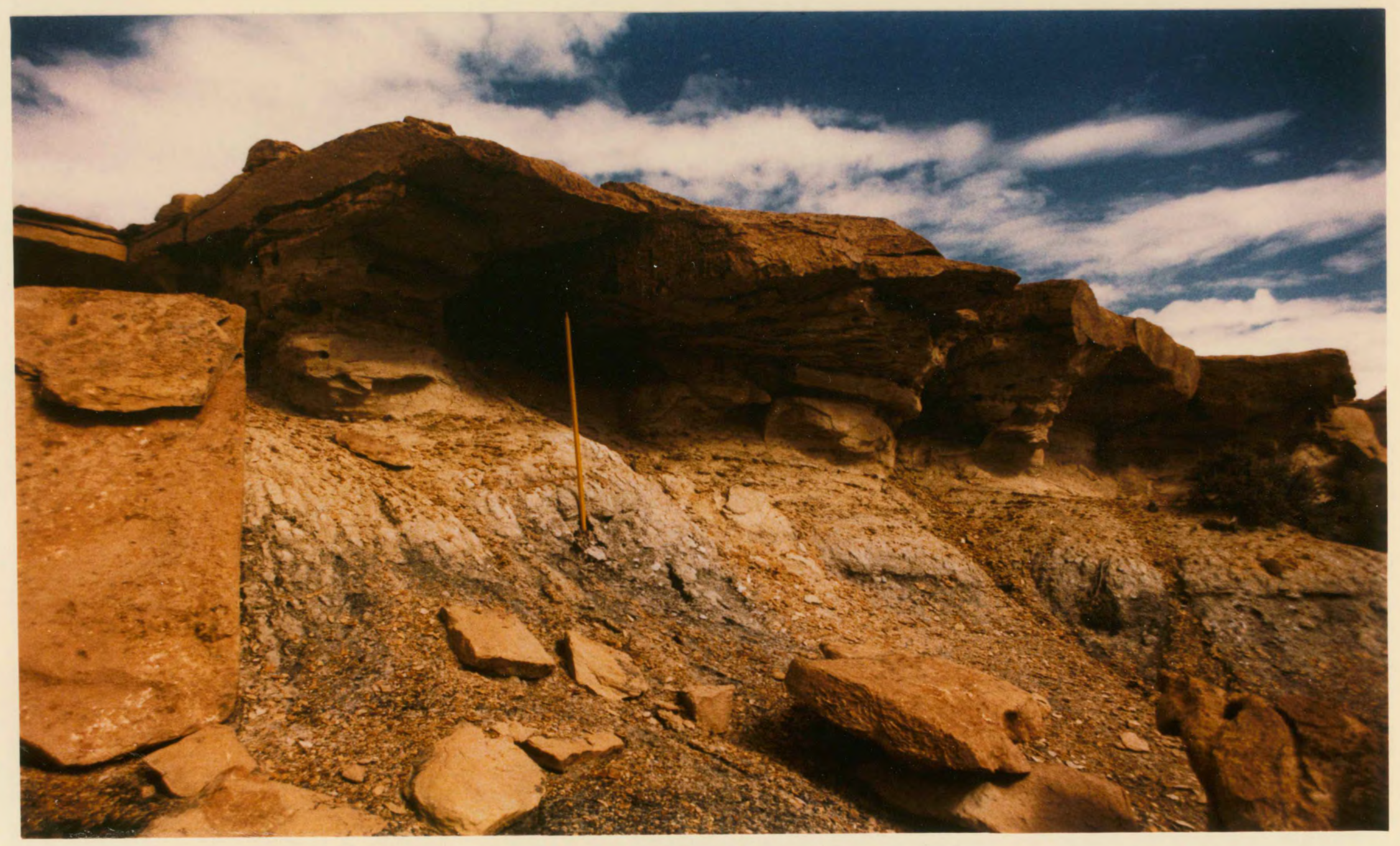

Figure 16. Sandstone types I and III. Dominant ledge-forming type III sandstone overlies light colored type I sandstone. 
Correlations between surface sandstones and those in the subsurface are less certain due to the lack of weathering and erosional effects.

Contacts are sharp between sandstone types I and III. as shown in Figure 16 or gradational, as with sandstone types II and adjacent lithotypes, both horizontally and vertically.

Siltstones are typically light gray to light brown, include varying amounts of sand and clay, and are found on sloping surfaces. In the subsurface, siltstones are usually olive gray to dark brown, sometimes micaceous, and are found with and without siderite bands. Carbonaceous material may be found along bedding planes, and numerous plant fossil fragments also occur. Complete leaves are relatively rare. Claystones are generally light brownish gray to gray in sloping surface sections, but may contain silt or cobblesized rip-up clasts such as those found in MS-86010. In the subsurface, these units are often light olive gray to dark brown, and sometimes shaly, rooted, or burrowed, with associated carbonaceous or woody material. In addition, claystones may be found associated with coal beds, usually as floor and frequently with slickensided surfaces along bedding planes. Claystones are typically laminated, but fissility in mudrocks of the area is very rare. Figure 17 illustrates siltstones and claystones in surface section. Coal seams are generally found to be the most consis- 


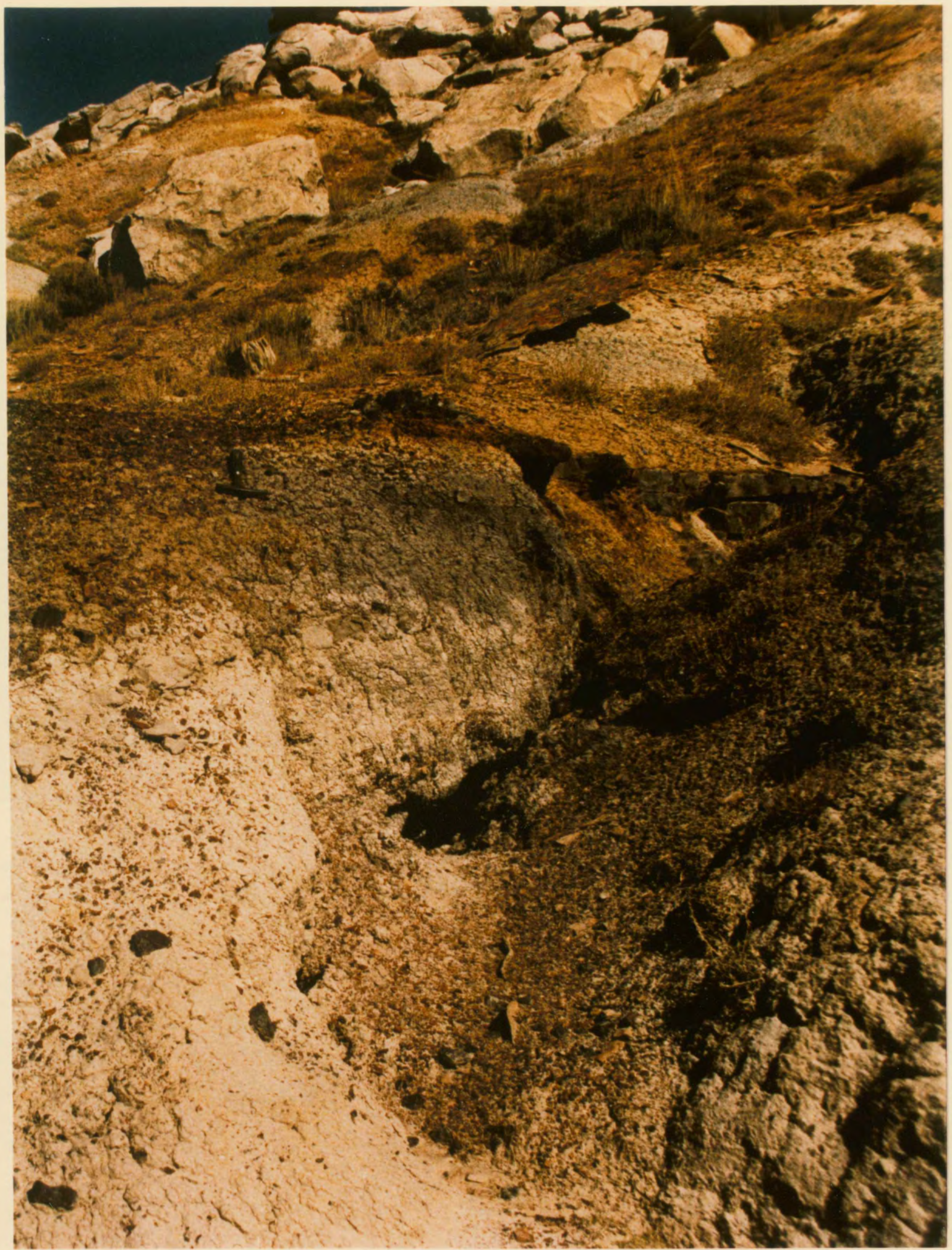

Figure 17. Siltstones and claystones in surface section. Rock hammer is just below a dark ironstone bed. 
tent lithologic units in terms of horizontal extent (Plates IIIA, IIIB, IIIC), They are typically weathered on outcrop, but are substantially less weathered even just a meter under the surface. The coal seams in the area of investigation are subbituminous $B$ to $C$ in rank, range from low to high in ash ( 7.56 to 14.11 percent), low to intermediate in sulfur $(0.50$ to 0.99 percent), intermediate in moisture (18.60 to 21.34 percent), and have average heating values of 8595 to $9597 \mathrm{BTU}$ (as received). In subsurface sections, the coal seams exhibit sharp contacts with subjacent and superjacent units, are generally unoxidized with low to moderate amounts of vitrinite, and locally contain thin partings of carbonaceous shale, claystone, siltstone, or sandstone. Surface coal exposures, on the other hand, are usually fairly well oxidized with weakly developed partings, and locally grade up or down section into claystone or carbonaceous shale, particularly towards the bottom. Figure 18 shows a particularly well exposed coal seam in the Tenmile Draw area. Further, surface sections sometimes encounter clinker (burned coal) deposits (Plate II).

Shales vary from light gray, olive gray, or brown to black. Plant material association is common in the subsurface, while small crystals of gypsum are rather commonly found at the surface. Shales are overall guite rare in the study area, and are very thin (less than 0.25 meters). Limestones are relatively common (although thin) in 


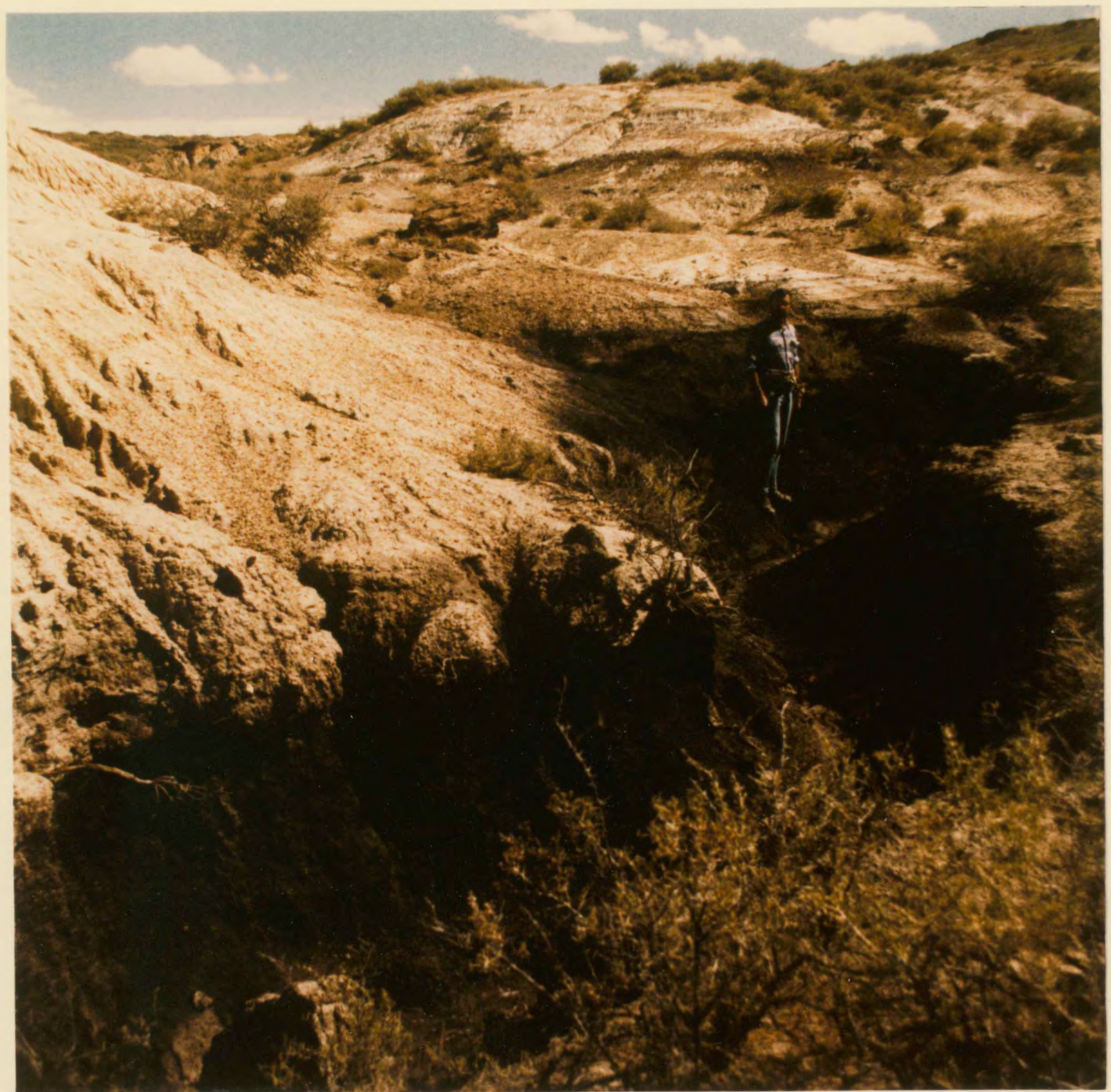

Figure 18. Well exposed coal seam in the Tenmile Draw area. 
the overburden, and relatively rare in interburden strata. These units are typically light gray to gray, micritic, and very well indurated; fossils are absent. Thicknesses range from 0.3 to 1.4 meters ( 1 to 4.5 feet). Generally, however, limestones are very discontinuous, and may only rarely be traced from one borehole to another.

\section{CHRONOSTRATIGRAPHY}

Some coal seams are laterally extensive, while others may be discontinuous, split, pinch out, or may contain substantial non-coal material. Peat swamps may develop in a wide range of depositional and tectonic circumstances and under varying paleotopographic conditions (Ward, 1984). The coal deposits of the southern portion of the Jim Bridger coal field, while exhibiting characteristics of all of the above, are dominantly of the laterally extensive type, being everywhere (within the study area) laterally continuous (except for the D3). The major coal seams are interpreted as relative time horizons, since it is presumed by nearly all workers in the region that swampy conditions existed in areas of low relief over broad expanses during early Paleocene time. Although certainly not as ideal a time marker as an ashfall event, for example, the progressive splitting of the coal seams is interpreted to be in response to tectonic (timed) events.

The following presents informal time-stratigraphic 
units for the lower portion of the Fort Union Formation in the study area. An attempt is made to provide rock-body descriptions so that future studies may concentrate on rock mechanics or depositional environments. Figure 19 is a generalized stratigraphic cross-section showing chronologic units and can be referred to throughout this section.

Underburden (Unit \#1 on Figure 19) is used to describe all rock units below the bottom of the $\mathrm{DI}$ or lowermost Deadman coal seam. The underburden is composed of varying quantities of sandstone, siltstone, and claystone. These sediments are frequently rooted, ripple laminated, contain carbonaceous material at the top lat the contact with the coal), are churned or bioturbated, and contain coal spars or coalified root material. A 0.2 to 1.5 meter 10.8 to 4.8 foot) coal bed, known locally as the Ute seam (Nielsen, 1984) is intermittently present about 12 meters (40 feet) below the bottom of the Lower Deadman (D31) seam. The underburden is frequently penetrated only a few meters when coring. The best information about the underburden is derived from the continuous core holes, when 20 meters $(66$ feet) or more of drilling has occurred below the D31 or D21 coal.

Although the Fort Union-Lance contact is known to exist not $f a r$ below the lowermost Deadman coal seam, the stratigraphic location of this occurrence has not been consistently confirmed by drilling. A fossil soil (Figure 20) 


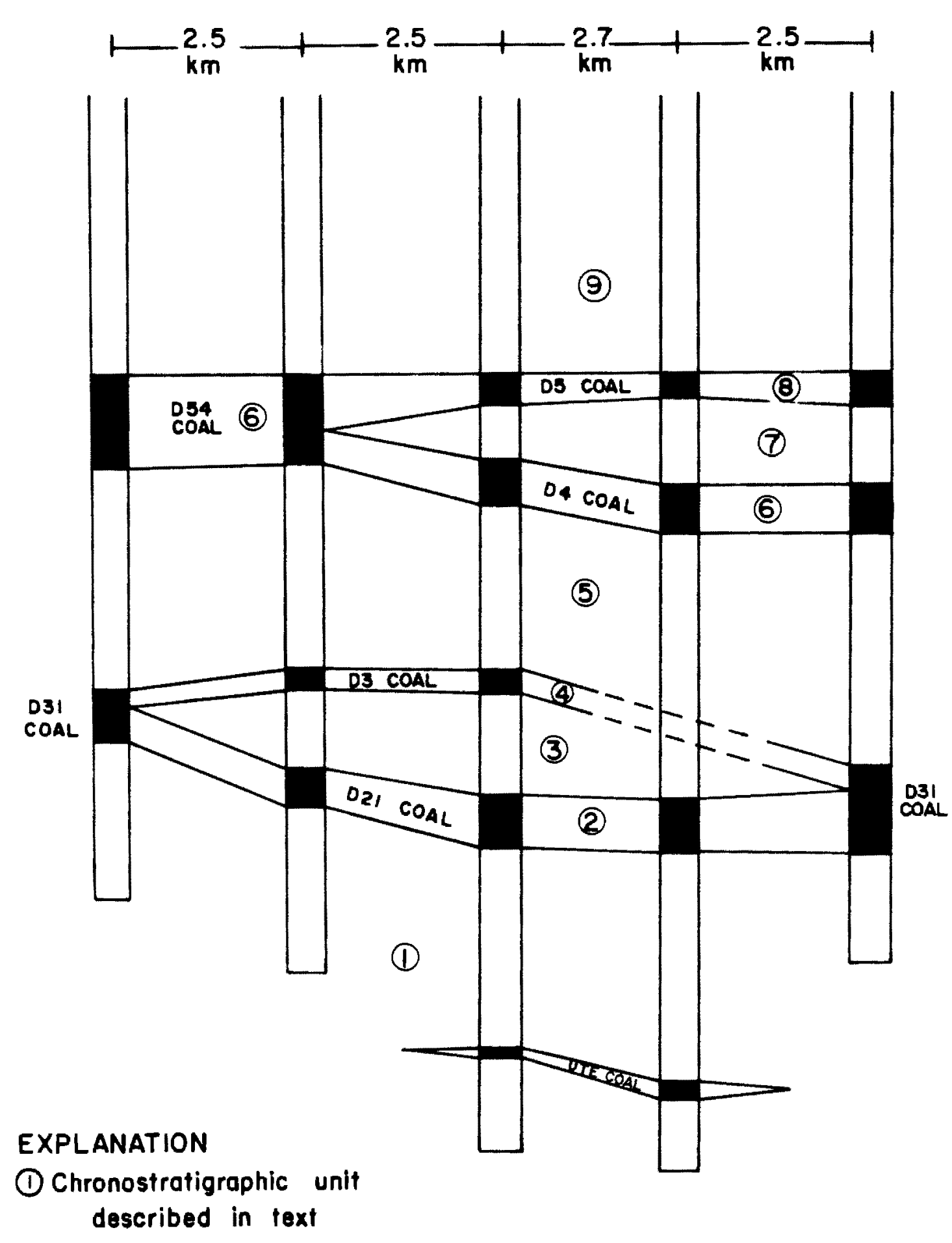

Figure 19. Generalized stratigraphic section showing chronologic units. 
has been mapped in the field at several localities but is stratigraphically lower in the section than what is cored in normal practice. In addition, this unit could be difficult to detect on geophysical log suites, its sandy nature being nearly identical to sandstone in gamma and density response. D31/D21 Coal (Unit \#2) ranges from 0.6 to 5 meters 12 to 16.5 feet) in thickness for the $D 31$ and from 0.5 to 4 meters ( 1.5 to 13 feet) thick for the D21. These beds are black, banded, dull to moderately bright in luster, and hard when unoxidized. The coal generally fractures blocky to semiconchoidally and contains small amounts of pyrite which occur as lenticular masses, euhedral crystals, framboidal aggregates, cell infillings, and as veins on cleat surfaces. Calcite, amber, elemental sulfur, and gypsum occur in trace amounts. In one small locality, a localized clastic parting occurs, which affects mineability of the D31 seam near its outcrop (Plate II). This parting, where present in minor amounts, increases ash content and mineral matter (chiefly silica) of the D3I seam. South of Tenmile Draw, ash increases and thermal quantity (BTU) decreases.

D32 Parting (Unit \#3) varies from 0.3 meters ( 1 foot) to 16.6 meters $(54.4$ feet) in thickness. It contains primarily very fine grained clastic sediments (siltstone, claystone, and shale) and varies from dark brown to light gray, but contains increasing amounts of sand in thicker interburden locations. However, the sandstone is usually found 


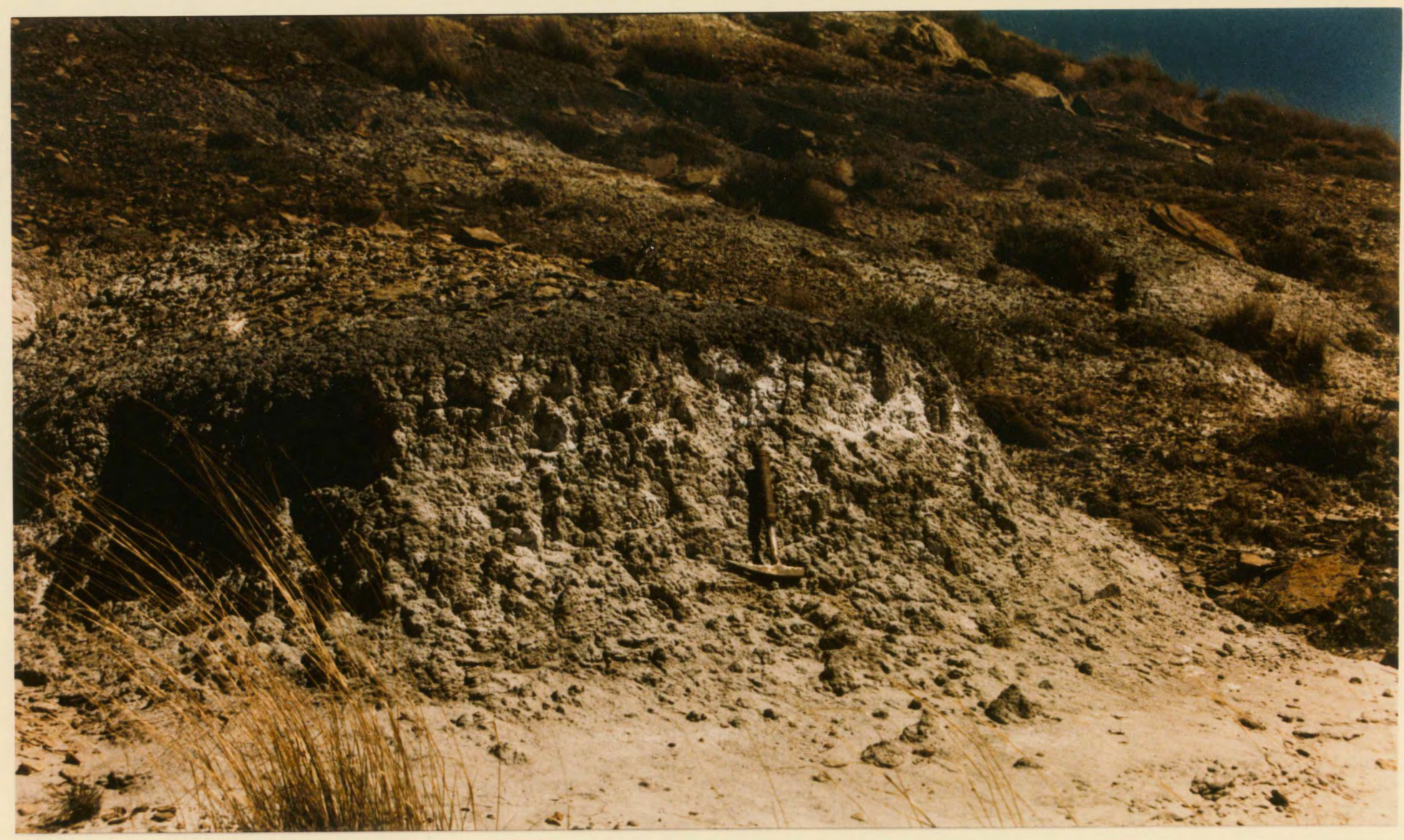

Figure 20. Fossil soil at base of Fort Union Formation in section 35, T20N, R100W. Note D31 coal outcrop at upper right. 
above or below a siltstone or claystone bed in contact with thick coal seams; sandstone occasionally occurs directly over the D21 seam. There are locally interbedded thin coals and carbonaceous laminae within the unit; limestone is rare. D3 Coal (Unit \#4), an upper 0.03 to 1.5 meter $(0.1$ to 5 feet) thick split of the 031 coal, is most often black, dull, very hard, and fractures irregularly to blocky. Pyrite occurrences are generally the same as for the $031 / D 21$ coal. However, since the D3 seam possesses fewer cleats than any other seam in the study area, this type of pyrite occurrence is much less common. Plate II also shows a 10calized area where the $D 3$ seam has either been eroded or is absent due to nondeposition. The $D 3$ coal thins in close proximity to these areas.

D43 Parting (Unit \#5) is continuous throughout the study area, varies in thickness from 2.1 to 22.6 meters (7 to 74.3 feet), and typically contains much more sandstone than the D32 parting. This unit is light gray to light brownish gray or light olive gray and contains siltstone, claystone, and shale. Brown to light gray, micritic, limestone is also much more common. Sediments in this unit exhibit siderite bands or nodules, ripple laminations and micaceous sandstones. Less common are pyrite nodules, carbonaceous plant material along bedding planes, thin (less than 0.25 meters) lenses of conglomerate, and flaser bedding. Rooted and carbonaceous claystones are common, particularly 
in contact with coal seams.

D54/D4 Coal (Unit \#6) ranges from 0.6 to 5.2 meters 12 to 17.1 feet) for the $D 54$ and from 0.5 to 3.5 meters $(1.5$ to 11.4 feetl for the D4. These seams are black, banded, moderately bright to bright, and generally hard but friable when unoxidized. This coal usually fractures conchoidally to blocky. It commonly contains visible calcium oxide on vertical cleats, and similar pyrite and accessory minerals as the D31/D21 coal. The D4 seam possesses the highest calorific (BTU) values of all coal seams in the study area. Clastic partings are relatively rare or very thin (less than 0.1 meter).

D54 Parting (Unit \#7) begins as a thin ( 0.3 meter) claystone member and includes siltstone if more than about one meter ( 3.3 feet) in thickness. Once this unit attains a thickness of about 3 meters (10 feet), sandstone becomes more prevalent. This unit reaches a maximum thickness of 12.4 meters (40.8 feet) and is usually light gray or light olive gray. Claystones contain siderite bands and some are carbonaceous with thin laminae. Limestones are rare. Lithologic relationships are well represented in Plate III. D5 coal (Unit \#8), ranging in thickness from 0.9 to 2.6 meters ( 3 to 8.5 feet), is similar in most respects to the D31/D21 coal except that it is somewhat thinner and the influence of clastic partings is markedly less severe, although some are still present, affecting ash content south 
of Tenmile Draw.

Overburden (Unit \#9) has sandstone as the chief constituent. These are cross-bedded, frequently contain ferruginous concretions, are sometimes contorted with slump structures, and contain very minor feldspar and traces of garnet and other minerals. Claystones are thinly laminated. Freshwater limestones are thin but relatively widespread. The overburden is primarily light yellow brown near the surface to light olive gray or gray in unweathered sections. Siderite bands are oxidized and leached near the surface. A thin ( 0.3 meter), persistent coal rider seam about 9 meters (30 feet) above the 054 coal has been traced from about two kilometers south of $91 / 2$ Mile Draw to almost as far north as Deadman Draw in the active mine area. This bed, although not of mineable thickness, is a useful marker bed.

\section{PALEOBOTANY}

Although scattered snail fragments have been found in the Fort Union Formation in the area of investigation, they are too broken up to be identified. Three identifiable fossil plants have been discovered, however.

A thin-bedded siltstone in section 26, T20N, R100W yielded a specimen of Cornus nebrascensis (Figure 21) from a surface exposure in overburden strata. This species of dogwood tree is common in the Paleocene (Brown, 1962).

A well-preserved fern, Selaginella (Figure 22), was 


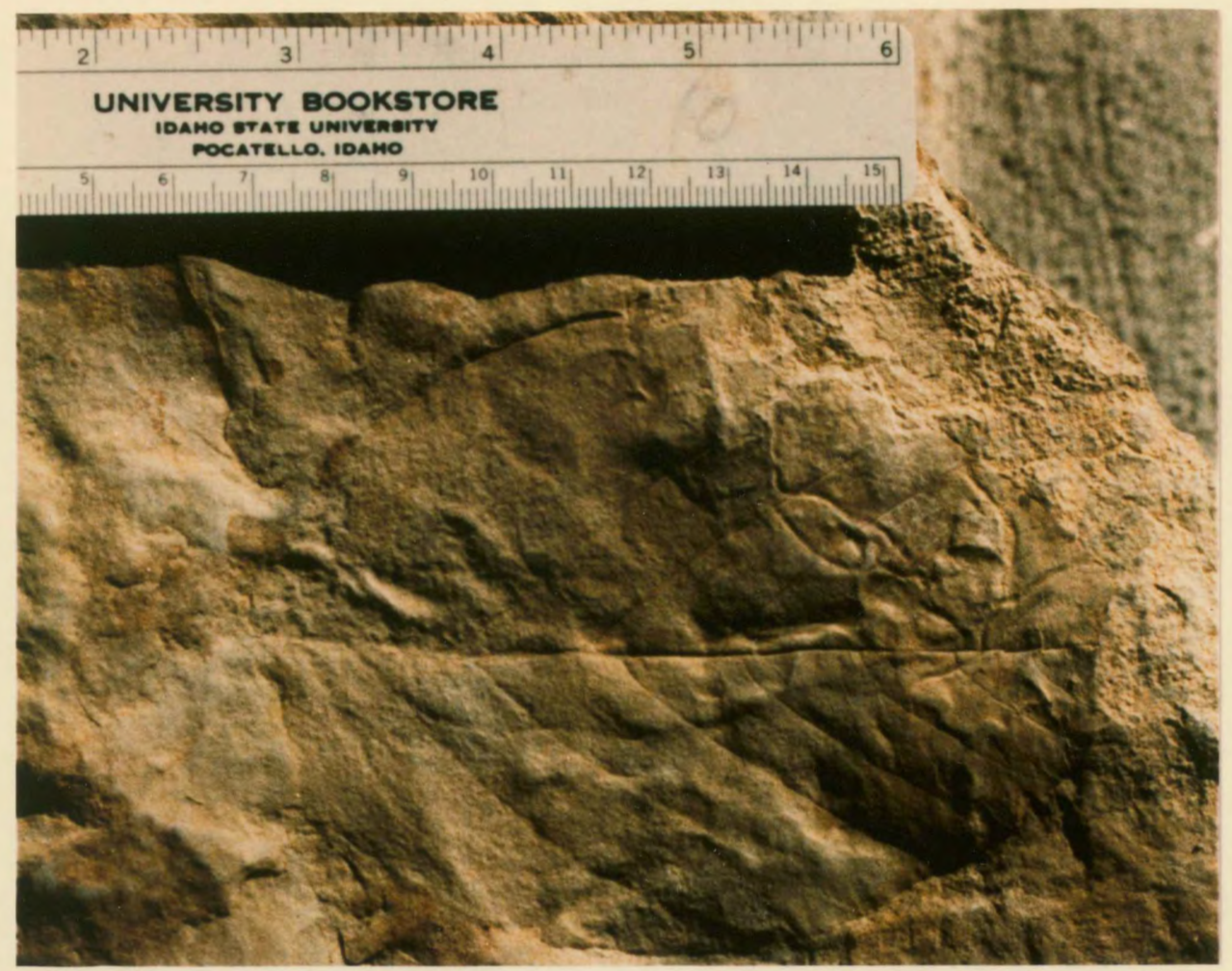

Figure 21. Cornus nebrascensis from section 26, T20N, R100W.

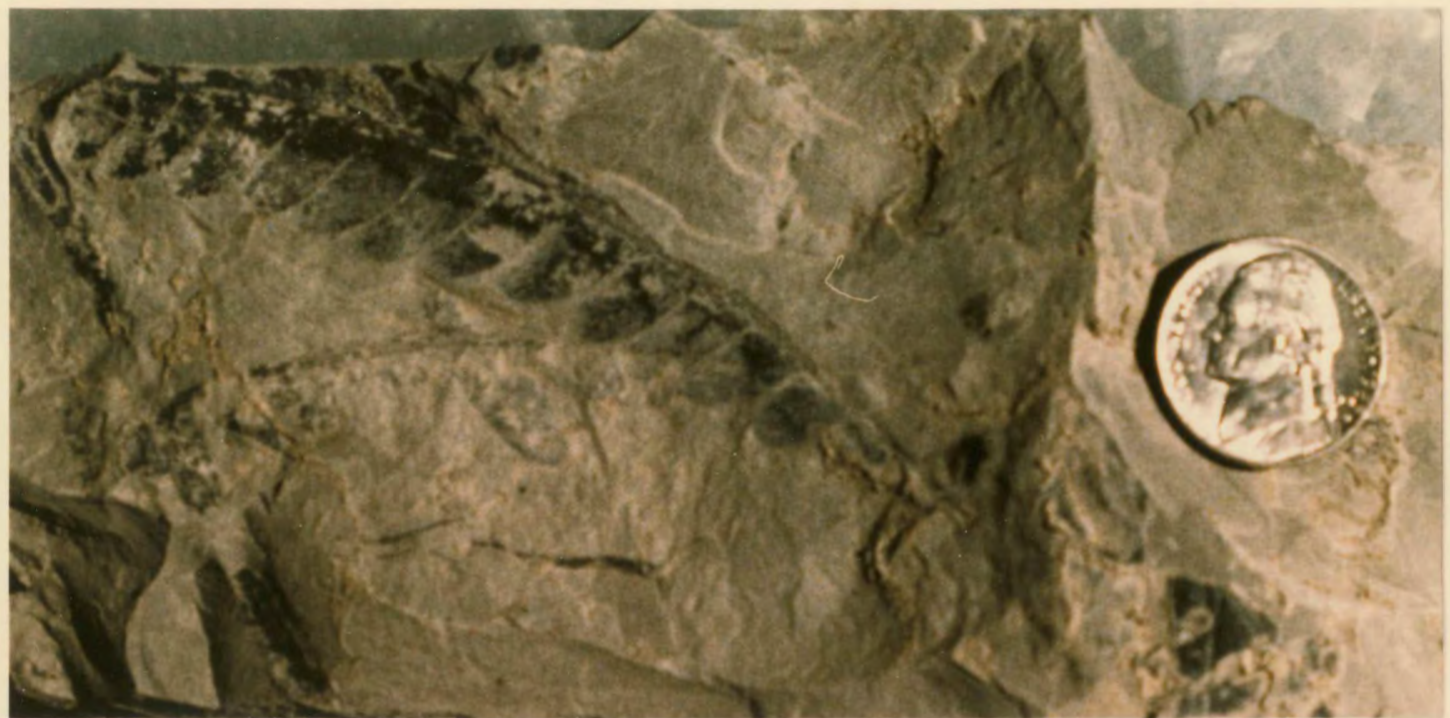

Figure 22. Selaginella sp. from section 35, T21N, R101W. 
found in massive claystone (interburden) at the northern edge of the study area in section 35, T21N, R100W. Several fern species have been found north of the study area, among these are Salvinia (?), a floating fern (Wing, 1984). An as yet unidentified monocot has been found in abundance in and around this locality. Also found here in a laminated siltstone were a few leaves of Cercidiphyllum, or katsura tree, a genus related to the shuihsa of China. Cercidiphyllum is an index fossil of the early Paleocene and commonly occurred along streambanks in moist, drained soils, but was rare or absent from swamps (Wing, 1984).

A large, sabal palm specimen was recovered from interburden claystone immediately overlying the D3I seam less than one mile north of $91 / 2$ Mile Draw (Figure 23). Known as the palmetto, Sabalites ranges into the Holocene and can be found living in Florida (S. Wing, paleobotanist, Dept. of Paleobiology, National Museum of Natural History, 1987. pers. comm.l.

Fragmental plant remains frequently can be located in surface section. These are often unidentifiable but are recognizable as twig, bark, root, or stem fragments. Evidence of past luxuriant plant life is confirmed by standing trunks approximately 8 meters (26 feet) in height coalified in situ in active pit highwalls immediately adjacent to the study area north of $91 / 2$ Mile Draw.

Further detailed paleobotanical studies are needed, 


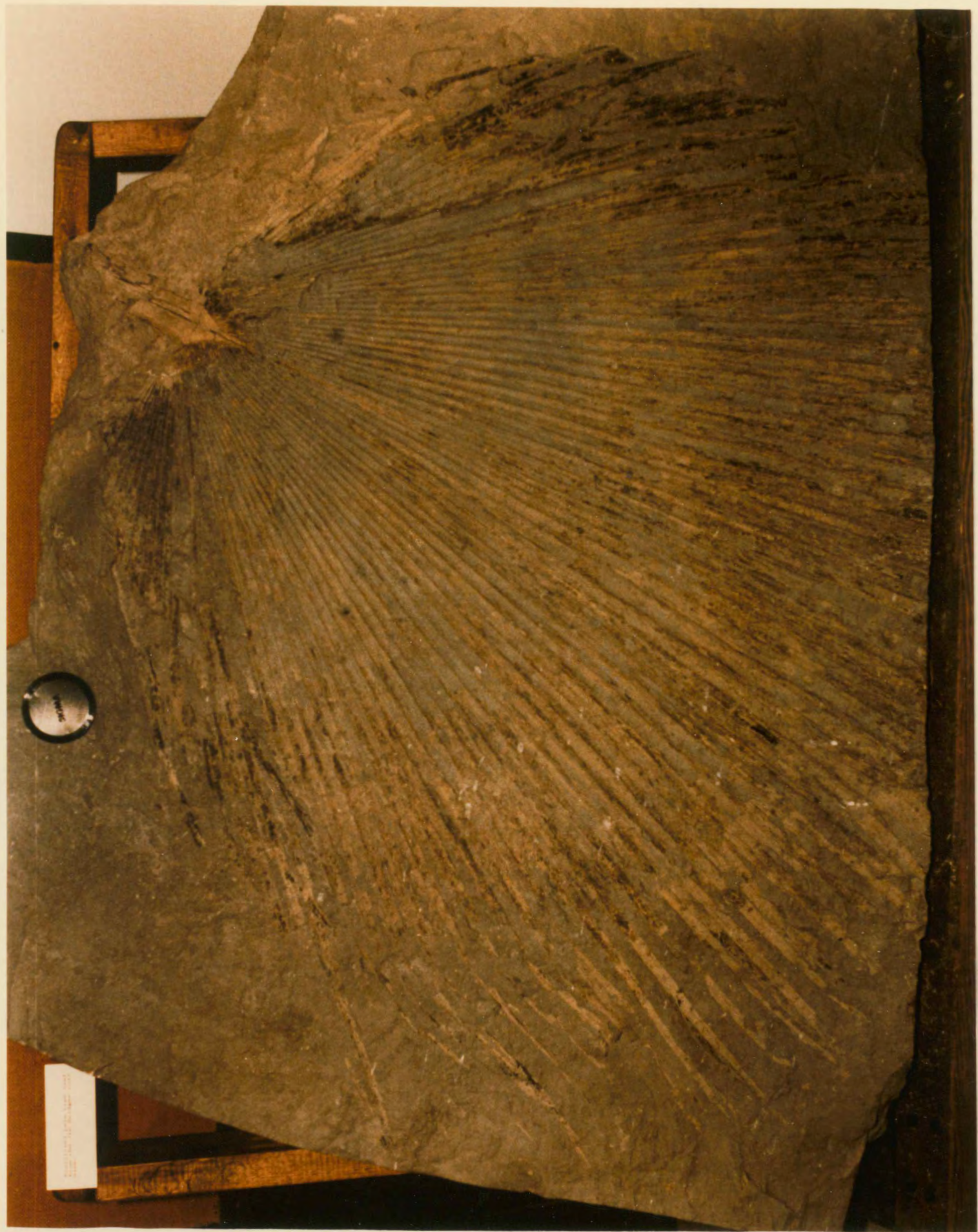

Figure 23. Sabalites sp. from section 34, T21N, R101W (approximate location). This specimen is approximately 1.3 meters (51 inches) across and is displayed at the Sweetwater County Historical Museum in Green River, Wyoming. 
as Brown (1962) recognized that many more plant species have transgressed the Cretaceous-Paleocene boundary than was formerly supposed. Active pit areas provide a virtual bounty of unweathered specimens. Paleobotany will also permit more accurate determination of the true age of the Fort Union Formation in the study area. 
CHAPTER 6

DISCUSSION AND INTERPRETATION

Regionally, unconformities flanking both the Rock Springs Uplift and the Douglas Creek Arch of northwestern Colorado are similar in structural symmetry and the two structures have fairly complete continuity except for where the Uinta Uplift has removed the evidence. The Douglas Creek Arch and the southern end of the Rock Springs Uplift have jointly been interpreted as a foreland fold in front of the cretaceous orogenic belt of central and northern Utah (Gow, 1950). The Douglas Creek Arch-Rock Springs Uplift structural element was a large anticlinal nose plunging northward. Major uplift of the Uintas occurred during the Early Paleocene (Picard, Bruhn, and Beck, 1983).

\section{Lance-Fort Union Contact}

A conglomerate bed has been mapped at the base of the Fort Union Formation around Baggs, Wyoming, near the Sierra Madre Uplift (Swain, 1957), as previously mentioned in Chapter 2. This layer is absent or undetectable near the study area. Schultz (1910), presumably working near the Black Buttes area, noted a conglomerate which he described as the boundary between the Black Buttes and Black Rock coal groups (basal Wasatch). Severn (1959) measured a surface section in sections 8 and $9, T 20 N$, R100W, and placed the Lance-Fort Union contact just below a 2.7 meter ( 9 foot) covered inter- 
val between two sandstones of similar lithologic characteristics. He generally failed to find the unit described by Schultz and assumed it to be intermittently exposed. However, Severn did encounter a conglomeratic unit in section 10 . T18N, R100W near Black Buttes (Figure 3; Plate I) which was noted as the "basal conglomerate of the Fort Union Formation."

Other workers mapping the eastern flank of the Rock Springs Uplift picked a massive, buff to white sandstone as the base of the Fort Union Formation in this area. The uppermost sandstone of Swain appears to be the same as the basal sandstone of Mogensen (1959), as pointed out in Chapter 2. Johnston's (1959) thesis reported the base of the Fort Union near the Table Mountains is marked by a distinctive, massive, buff sandstone about 6.1 meters (20 feet) thick. Photographs taken by Mogensen near Black Butte bear striking resemblance to sandstones and associated cavernous weathering in the upper units of the Lance Formation noted in the area of investigation.

Finally, the presence of a fossil soil bed was first described by Ritzma (1955) and further studied by Ritzma (1965) and Land (1972). Once recognized as a paleosol, this horizon was mapped by the writer in several localities. A maximum of 2.2 meters ( 7.2 feet) was cored near measured section MS-86009. The fossil soil consistently lies several meters above the base of the white sandstone and less than 
one meter to greater than five meters below the D31 or D21 seams. However, the paleosol in question, that used to denote the lower contact of the Fort Union Formation with the underlying Lance Formation, could be confused at times with up to three other paleosol horizons within the lower portion of the Fort Union. The Lance-Fort Union boundary paleosol can be found consistently in surface sections below mineable Deadman coals, where these are present.

Bown and Kraus (1987) found an inverse relationship between soil maturity and short-term sediment accumulation rate, based on studies of the paleosols of the Lower Eocene Willwood Formation in northwestern Wyoming. Immature soils found in Latest Cretaceous Hell Creek and Paleocene Tullock Formations in Montana and western North Dakota formed in a poorly drained environment with a fluctuating water table (Fastovsky and McSweeney, 1987). Ancient pedogenesis patterns in many regions are becoming more clearly understood. The Lance-Fort Union boundary paleosol in the area of investigation is interpreted to have characteristics similar to Stage-1 (immature) paleosols of Bown and Kraus (1987). This is based upon close (hand lens) visual examination of the horizon best exposed in the southern portion of the study area (Figure 20).

Although the existence of an unconformity at the Lance-Fort Union contact was disputed by some earlier workers (Swain, 1957; Mogensen, 1959), a majority consensus 
would support existence of an unconformity (Ritzma, 1955; Smithson, 1959; Johnston, 1959; Land, 1972). Field evidence for an unconformity can be seen where Fort Union sediments rest directly upon Almond Formation rocks on the western flank of the Rock Springs Uplift (Plate I) and on the eastern flank of the uplift the Fort Union rests upon the Lewis Shale at the northern and southern portions of the structure. At the midpoint of the Rock Springs Uplift on the eastern flank (near the southern end of the study area), however, angular discordances between the Lance and Fort Union are less discernible--probably on the order of one to two degrees and become practically unnoticeable with slumping and erosion occurring at outcrop. Figure 24 illustrates some of these relationships, including the continuous nature of the fossil soil horizon, as interpreted by the writer. An unconformity also exists between the Fort Union and Wasatch Formations (Davis, 1958), but was not studied during this investigation.

Although Swain worked primarily along the western margins of the Sierra Madre, the observations of Mogensen probably did not take into account these regional structural characteristics. The Lance Formation was apparently severely truncated by erosion in Late Cretaceous or Early Paleocene time, a concept favored by Weimer (1970). This event was followed by the overlapping of the onlapping Fort Union. Mogensen's claim that the entire interval of Paleocene depo- 
SOUTH $\longrightarrow$ MORTH

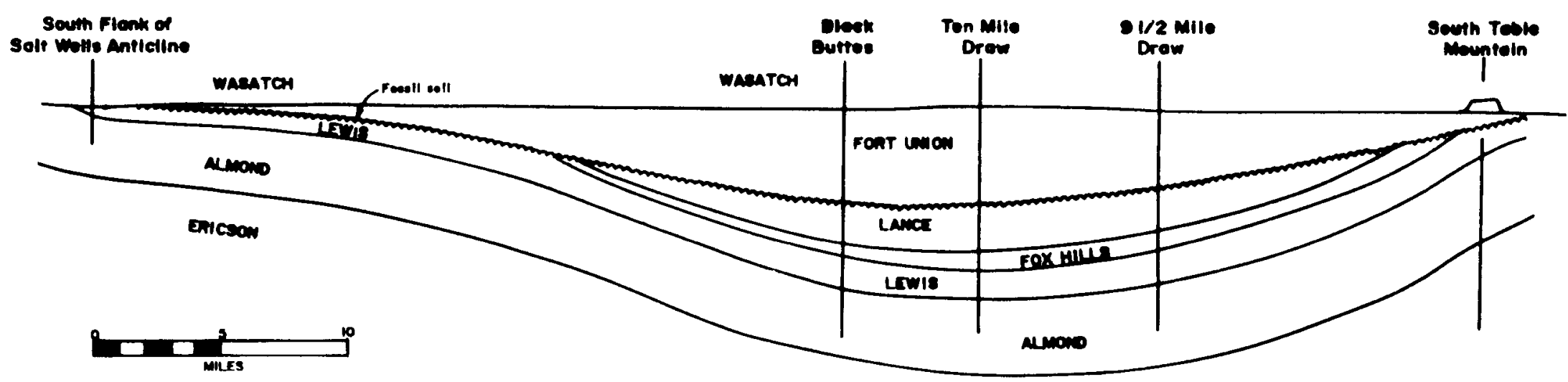

Figure 24. Generalized cross section through Upper Cretaceous and Lower Tertiary rocks, east flank of the Rock Springs Uplift (modified from Ritzma, 1955). 
sition is represented by the Fort Union Formation cannot be substantiated in the Rock Springs Uplift area.

Structural Regime

The southern portion of the Jim Bridger coal field is generally unaffected by faulting (Plate II), with the exceptions of the following:

Ten Mile Draw--two faults are postulated south of the drainage on most regional geologic maps. It would appear that two faults are needed to explain the radical and deep coal stratigraphy in boreholes 147,267 , and 80085-80096. The illustrated interpretation is an attempt to explain subsurface stratigraphic conditions.

Southern Permit Boundary--two faults are postulated on most regional geologic maps. Although both faults are plotted on Plate II, the location of only the more northerly fault is known by the investigator to any degree of certainty, as borehole 85040 straddles the fault plane.

Regional dips are low, ranging from one to five degrees. Other faulting has been identified as fairly minor. All faults mapped as a part of this study conform to interpreted regional trends.

\section{MODES OF DEPOSITION}

Although detailed studies of depositional environments are beyond the scope of this study it is important to discuss some generalizations. Specifically, it should be in- 
teresting to compare the Fort Union Formation in the southern portion of the Jim Bridger coal field with the equivalent unit in the Powder River Basin.

Peat formation requires luxuriant vegetative growth with at least some woody or fibrous components, sufficient standing water to prevent oxidation of the organic matter, and the absence of sediment or clastic debris (Ward, 1984). Swamp plants themselves commonly provide baffles and barriers to sedimentary detritus with their extensive root systems.

The importance of high annual rainfall in contributing to the establishment of an elevated water table has often been overlooked. Crevassing and avulsion would otherwise prohibit raised peat swamps from developing extensively (McCabe, 1984). Relief of these swamps inhibits detrital influx and channel migration and avulsion (Flores, 1984; McCabe, 1984).

Flores (1980) demonstrated that concerns of coal exploration such as thickness, lateral continuity, aerial distribution and quality of coals in the Western Interior are directly related to depositional environment. A variety of settings may be responsible for peat formation. Frequently, extensive swamps may accumulate in river floodplains, lakes, deltas, and coastal areas (Ward, 1984), but less extensive and therefore less economically significant coal deposits may be preserved in other, isolated stagnant-water bodies. 
Inland freshwater or fluvial coals formed away from marine influence can generaliy be expected to contain much lower sulfur than marine coals (Frazier and Ozanik, 1969). Combine this with low to moderate ash fKaiser, 1974; Fisher, 1968), and fluvial coals begin to show the desirable characteristics of a clean, low-polluting energy source. Some investigations (Jacob, 1973, 1975; Wanless et al., 1969; Ferm and Horne, 1979) have shown that maximum coal thickness occurs in deltaic coals. However, because of mining in deltaic environments, this has led in some areas to exploration and definition of fluvial coal-forming environments.

Anastomosed. streams have been defined by Smith and Smith (1980, p. 157-158) as those which have "an interconnected network of low-gradient, relatively deep and narrow, straight to sinuous channels with stable banks composed of fine-grained sediment (silt/clay) and vegetation... . Separating the channels are floodplains consisting of vegetated islands, natural levees, and wetlands." Anastomosing fluvial systems have been interpreted to produce several major coal deposits (Leblanc smith and Eriksson, 1979; Cairncross, 1980; Smith and Putnam, 1980; Flores and Hanley, 1974; Budai and Cummings, 1987). Fort Union Formation, Powder River Basin The extensive literature describing the coal-bearing rocks of the Powder River Basin shall be summarized briefly here. Much of this work has been done in the late 1970 s and 
1980 s in response to mining interests and oil and gas exploration potential.

The Powder River Basin of northeastern Wyoming and southeastern Montana is a large, asymmetrical basin about

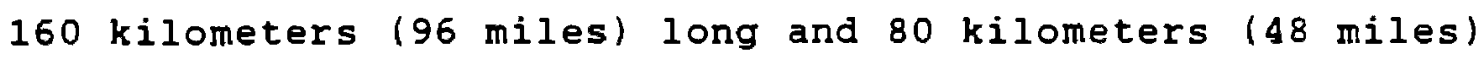
wide (Figure 1). The Fort Union Formation in this area is divided into the Tullock, Lebo, and Tongue River Members (Ayers and Raiser, 1984).

The Tongue River Member, the major coal-bearing unit in the basin, has been interpreted by Flores (1979, 1980, 1981) to consist of alluvial, fluvial-lake, and fluvial environments based upon measured surface sections. Ayers and Kaiser (1984) proposed paludal and lacustrine-interdeltaic models, based upon surface and extensive subsurface data.

In the southern Powder River Basin, Sharp and Gibbons (1964) proposed a northward-flowing, mixed-load system which spread mud across its floodplain during flood stages. Later studies in the same area described fine-grained meander belt systems (Jackson and Ethridge, 1979) in addition to northward-flowing mixed- to bedload channel systems (Galloway, 1979) which interfingered laterally with and evolved downslope into mixed- and suspended-load systems with gradually changing gradients.

In the northern Powder River Basin, Flores and Hanley (1984) proposed large-scale anastomosis which served as a downflow continuum of basin-margin, conglomeratic, braided 
and meandering tributary systems. They suggested that this was initiated by tectonic causes related to the Cedar Creek Anticline in southeastern Montana.

Southern Portion of the Jim Bridger Coal Field

Studies by Swain (1957) and Beaumont (1979) of the Fort Union Formation in the Sierra Madre region suggest that source areas in the major uplifted areas of the Early Paleocene (Park Range, Sierra Madre, and Uinta Uplift) were responsible for supplying gradients and sediments to northward-flowing streams in the Sand Wash and Washakie Basins. High sinuosity streams were replaced by low sinuosity, coalbearing systems in the upper Fort Union of the Sand Wash Basin. Paleobotanical evidence is suggestive of a warm, moist climate near a low elevation.

The Allegheny deltaic model developed by Horne et al. (1978) has been successfully applied to many coal deposits worldwide. The transitional facies between lower and upper delta plain deposits would appear to explain thick, laterally extensive coal seams, but breaks down when taking into account observed high sand-clay ratios and brackish to marine fossils required for the Allegheny model. Conversely, observed high sand-clay ratios at Jim Bridger fit the upper deltaic plain facies of Horne et al.'s model, but cannot explain thick, laterally continuous coal seams.

The Lower Paleocene in the southern portion of the Jim Bridger coal field has a very high sandstone-claystone ratio 
(about 3.6 to 1 ). Studies of ancient channel occurrences in overburden north of the study area indicate low sinuosity and high width to depth ratios. Thus it would appear that this vertical facies interval has a good correlation with a braided (low sinuosity) model.

The linear distance to the wind River Mountains, about 66 kilometers $(40$ miles) from the study area, would tend to indicate a reasonably acceptable gradient for a braided model. Anastomosed channels have high depth/width ratios (Smith and Putnam, 1980), higher than those observed in the study area. However, few lateral accretion surfaces that have been observed in active pit regions in interburden strata exhibit narrow (around 1 meter), relatively deep channels. Whether these features are anastomosed, or are merely small tributaries, remains to be confirmed with future studies.

Gradients decreased and meander belts became stabilized during late Fort Union time as the increasing amounts of clays (up to 95\%) inhibited lateral channel migration, compacted and contributed to stable, high sinuosity flood plain characteristics (Royse, 1970). No coal is found in this part of the Fort Union, reflecting better drainage conditions.

Paleocurrent directions measured in the northwest portion of the study area (Figure 25) suggest a northerly sediment source. Hand specimen recognition of abundant (up to 


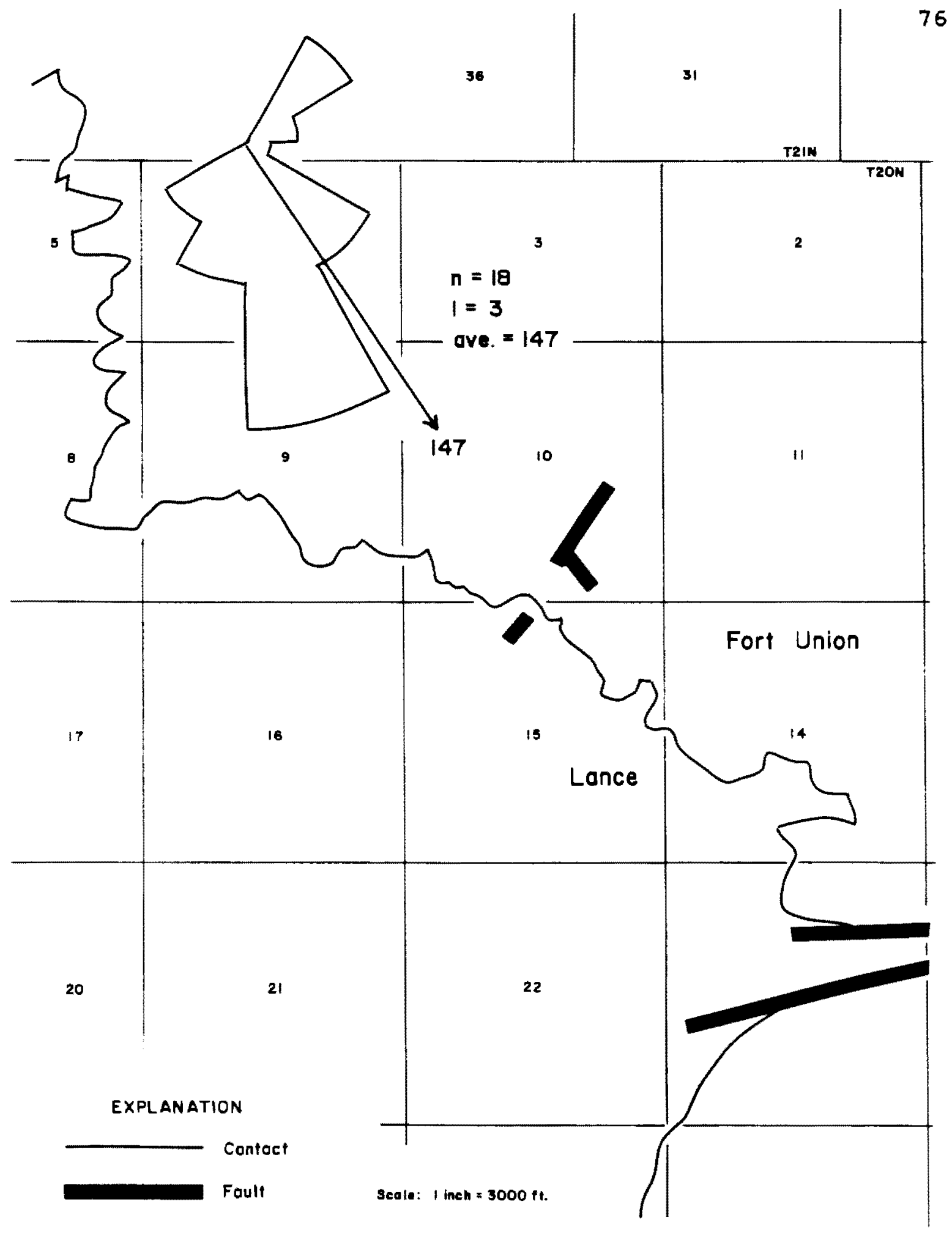

Figure 25. Paleocurrent directions, northwest portion of study area. 
about 10\%) muscovite grains would tend to support this hypothesis, since the southern wind River Mountains contain the only active sediment source during the Paleocene with requisite plutonic rocks, with the Precambrian cores of the more northerly Washakie and Owl Creek Ranges being only locally exposed during the Paleocene (Courdin and Hubert, 1969) .

The name "Fort Union Formation" in southwestern Wyoming has been extended so far from its type area that it is used to denote a time-transgressive unit rather than a rockstratigraphic unit (Swain, 1957). Mid- to Late-Paleocene coals in the Powder River Basin are referred to the Fort Union while most of the Fort Union coals around the Rock Springs Uplift are thought to be earliest Paleocene (Puercan). Only through detailed paleobotanical and palynological studies will the true ages of these sediments be determined, and a greater degree of understanding achieved thereby . 
CHAPTER 7

\section{APPLICATION OF STRATIGRAPHIC MODEL}

There are several areas of the mining operation which will benefit from using the stratigraphic model. Many of these applications are aimed at reducing unit costs or pinpointing potential problem areas before mining.

Studies by Crosby $(1985,1986)$ have shown that detailed stratigraphic knowledge combined with joint set mapping can be used to determine suitability of an area for cast blasting. The factors most affecting the suitability for this type of blasting are highwall stability and the presence and amount of groundwater. Success of conventional or cast blasting is reliant upon identification of lateral and vertical rock variabilities. The stratigraphic model will be particularly valuable in potential mining areas with deep overburden, where blasting efficiency is more critical. In addition, this model will lay necessary groundwork for future rock mechanics and other engineering evaluations.

The use of depositional models in mine planning has relied on detailed stratigraphic studies (Horne, et al., 1978). Further depositional studies are often undertaken in an effort to predict coal quality trends. Sodium oxide and other mineral matter content, and sulfur distribution affect combustion, contractual mineability, and blending potential (Hackley, 1984; Cohen, Spackman, and Dolsen, 1971). Future 
stratigraphic and depositional studies can be incorporated with groundwater hydrology concepts to determine potential pit water inflow areas. Drilling and coal coring targets for future years can be identified. Enough data have become available in recent years to permit detailed, reliable rock geochemical-lithostratigraphic correlations with in situ coal chemistry parameters, which could prove very useful to predictions of potential toxic zones for reclamation planning. During times of reduced profit margins and increased foreign competition, domestic coal mining companies today must take advantage of all geological resources available.

\section{CONCLUSIONS AND RECOMMENDATIONS}

Twenty-nine surface sections and 581 subsurface (borehole) sections were evaluated and used to construct a stratigraphic model of the southern portion of the Jim Bridger coal field. Mainframe-computer-resident software, such as LOGPLOT and STRATVIEW were used where possible to assist in production of a fence diagram of the study area. The stratigraphic model includes 1 ithologic and chronologic units.

Sandstone $(60 \%)$, claystone $(17 \%)$, siltstone (11\%), coal (10\%), and limestone (2\%) are found to be the most abundant lithologic units and exhibit a high degree of lateral and vertical variability. Lateral continuity of major coal seams is shown to be useful for informal stratigraphic 
purposes. Fossil flora examined in and near the study area include cornus nebrascensis (dogwood), Selaginella (fern), Salvinia (a floating fern), Cercidiphyllum (katsura), and Sabalites (palm) and indicate accumulation under warm temperate to subtropical conditions.

The Lance-Fort Union contact is mapped immediately above a distinctive fossil soil horizon up to 2.2 meters (7.2 feet) thick. Multiple paleosols exist within the lower Fort Union, so the formational contact is placed below the lowest significant coal, where present. High sandstone percentages and a noticeable lack of lateral accretion surfaces are interpreted to define sedimentation in low sinuosity, perhaps braided, stream environments. Paleocurrent directions infer a northerly source, probably the wind River Range.

Southward-flowing streams from the Wind River Range shed sediments into active depocenters in the Jim Bridger area during the Early Paleocene. Eroding highlands in Colorado (White River Plateau?, Sierra Madre, Park Range) were also sources of sediment filling the basin from the south. Since the Rock Springs Uplift had begun rising to the west, major drainage must have been to the east through what is now the Washakie Basin.

Further depositional studies could emphasize computer contouring and geostatistics to confirm source areas and possible Markov analysis to separate random depositional 
events from normal ordered events. Lateral and vertical variabilities are so great that continued mapping in the study area will be necessary to further understand the complex rock-body geometries.

Future work will need to be emphasized in the highwall stability and blasting optimization areas. Subsequent but no less important opportunities for contributions will come in the fields of paleobotany, geochemistry, and paleosol stratigraphy. 


\section{REFERENCES}

Ayers, W.B., Jr., and Kaiser, W.R., 1984, Lacustrine-interdeltaic coal in the Fort Union Formation (Palaeocene) Powder River Basin, Wyoming and Montana, U.S.A., in Rahmani, R.A., and Flores, R.M., eds., Sedimentology of Coal and Coal-bearing Sequences: International Assoc. of sedimentologists, spec. Pub., Volume 7, p. 6184 .

Beaumont, E.A., 1979, Depositional environments of Fort Union sediments (Tertiary, northwest colorado) and their relation to coal: Am. Assoc. Petroleum Geologists Bull., v. 63 p. 194-217.

Blackstone, D.L. Jr., 1955, Notes on a tectonic map of parts of southwestern Wyoming and adjoining states: Wyoming Geol. Assoc. Guidebook 10th Ann. Field Conf., p. 122124 .

Bown, T.M., and Kraus, M.J., 1987, Integration of channel and floodplain suites, I. Developmental sequence and lateral relations of alluvial paleosols: Journal of sedimentary Petrology, v. 57, p. 587-601.

Bradley, W.H., 1945, Geology of the Washakie Basin, Sweetwater and Carbon Counties, Wyoming, and Moffat County, Colorado: U. S. Geol. Survey Oil and Gas Map 32.

1961, Geologic map of a part of southwestern Wyoming and adjacent states: U. S. Geol. Survey Misc. Geol. Investigation Map I-332, scale 1:250,000.

Brown, R.W., 1949, Paleocene deposits of the Rocky Mountains and Plains: U. S. Geol. Survey Prelim. Map.

1962, Paleocene floras of the Rocky Mountains and Great Plains: U. S. Geol. Survey Prof. Paper 375, 257 p.

Budai, C.M., and Cummings, M.L., 1987, A depositional model of the Antelope coal field, Powder River Basin, Wyoming: Journal of Sedimentary Petrology, v. 57, p. 3038 .

Cairncross, B., 1980, Anastomosing river deposits: paleoenvironmental control on coal quality and distribution. northern Karoo Basin: Transactions of the Geological Society of South Africa, v. 83, p. 327-332. 
Carey, B.D., 1955, A review of the geology of Leucite Hills: Wyoming Geol. Assoc. Guidebook 10th Ann. Field Conf., P. 112-113.

Cohen, A.D., Spackman, W., and Dolsen, C.P., 1971, Occurrence and distribution of sulfur in peat-forming environments of south Florida (Abstract): Geol. Soc. America Abstracts with Program, v. 3, p. 528.

Compton, R.R., 1962, Manual of field geology: New York, John Wiley and Sons, $378 \mathrm{p}$.

Courdin, J.L., and Hubert, J.F., 1969, sedimentology and Mineralogical differentiation of sandstones in the Fort Union Formation (Paleocene), Wind River Basin, Wyoming: Wyoming Geol. Assoc. Guidebook 21st Ann. Field Conf. . p. 29-37.

Crosby, W.A., 1985, Visit to Bridger Coal Company--June 1985: Mining Resource Engineering Ltd. unpubl. report, $54 \mathrm{p}$.

1986, Visit to Bridger Coal Company--March 1986: Mining Resource Engineering Ltd. unpubl. report, 41 p.

Cross, W., and spencer, A.C., 1899, U.S. Geol. Survey La Plata Folio 60: Washington.

Curry, W.H. III, 1969, Synthetic electric logs in subsurface mapping: Wyoming Geol. Assoc. Guidebook 24 th Ann.

Field conf. p. 93-98.

Davis, R.W., 1958, Stratigraphy of the Wasatch Formation, east flank of the Rock springs Uplift, Sweetwater County, Wyoming: M.A. thesis, University of Wyoming, $76 \mathrm{p}$.

Dedman, E.V., Lindsey, J.P., and Schramm, M.W., 1975, Stratigraphic modeling: A step beyond bright spot: World Oil, v. 180, no. 6, p. 61-65.

Dorf, E., 1938, Upper Cretaceous floras of the Rocky Mountain region: Carnegie Inst. of Washington Pub. 508, p. $1-78$.

Eardley, A.J., 1951, Structural geology of North America: New York, Harper and Brothers, $624 \mathrm{p}$.

Fastovsky, D.E., and McSweeney, R., 1987, Paleosols spanning the Cretaceous-Paleogene transition, eastern Montana and western North Dakota: Geol. Soc. America Bull., v. 99, p. 66-77. 
Ferm, J.C., and Berger, J.T., 1979, A computer graphics system preparing coal bore hole data for mapping: Computer Graphics, v. 2, no. 8, p. 20-26.

Ferm, J.C., and Horne, J.C., 1979, Carboniferous depositional environments in the Appalachian region: Dept. Geology, University of South Carolina, Columbia, S.C., $760 \mathrm{p}$.

Fidlar, M.M., 1950, Structural features of the Green River Basin in Wyoming: Wyoming Geol. Assoc. Guidebook 5 th Ann. Field Conf., Southwest Wyoming, p. 86-87.

Fisher, W.L., 1968, Variations in lignites of fluvial, deltaic, and lagoonal system, Wilcox Group (Eocene) Texas (Abstract): Geol. Soc. America Ann. Meeting Program with Abstracts, p. 97.

Fisk, E.P., 1967, Groundwater geology and hydrology of the Great Divide and Washakie basins, south central Wyoming: M.S. thesis, University of Southern California, $132 \mathrm{p}$.

Flores, R.M., 1979, Coal depositional models in some Tertiary and Cretaceous fields in the U.S. Western Interior: Organic Geochemistry, no. 1, p. 225-235.

1980, Comparison of depositional models of Tertiary and Upper Cretaceous coal-bearing rocks in some Western Interior basins of the United States: 1980 Proceedings of the 4 th Symposium on the Geology of Rocky Mountain Coal; Colorado Geol. Survey Resource Series 10 , p. 17-20.

1981, Coal deposition in fluvial paleoenvironments of the Paleocene Tongue River Member of the Fort Union Formation, Powder River area, Powder River Basin, Wyoming and Montana, in Ethridge, F.G., and Flores, R.M., eds.. Recent and Ancient Nonmarine Depositional Environments: Models for Exploration: Soc. Econ. Paleon. and Mineralog. Spec. Pub. 31, p. 169-190.

1984, Comparative analysis of coal accumulation in Cretaceous alluvial deposits, southern United States Rocky Mountain basins, in stott, D.F., and Glass, D.J.. eds., The Mesozoic of Middle North America: Canadian Soc. Petroleum Geologists Memoir 9, p. 373-385. 
Flores, R.M., and Hanley, J.H., 1984, Anastomosed and associated coal-bearing fluvial deposits: Upper Tongue River Member, Palaeocene Fort Union Formation, northern Powder River Basin, Wyoming, U.S.A., in Rahmani, R.A., and Flores, R.M. eds., sedimentology of Coal and Coal-bearing Sequences: International Assoc. of Sedimentologists Spec. Pub., Volume 7, p. 85-103.

Frazier, D.E., and Ozanik, A., 1969, Recent peat depositsLouisiana coastal plain, in Dapples, E.C., and Hopkins, M.E.. eds., Environments of Coal Deposition: Geol. Soc. America Spec. Paper No. 114, p. 63-85.

Frink, A.P., Wittick, T.R., and Dedman, E.V., 1977, Interpretive methods of stratigraphic modeling: Preprint, oil Technology Conf., Houston, May 2-5, 1977.

Galloway, W.E., 1979, Early Tertiary--Wyoming intermontane basins in Galloway, W.E., Kreiter, C.W., and McGowan, J.H., eds., Depositional Ground-water Flow Systems in the Exploration for Uranium--A Research Colloquium: Bureau of Econ. Geol., University of Texas, Austin, p. 197-213.

Gill, J.R., and Cobban, W.A., 1966, Regional unconformity in Late Cretaceous, Wyoming: Geological survey Research, U. S. Geol. Survey Prof. Paper 550-B, P. B20-B27.

Glass, G.B., 1978, Review of Wyoming coal fields: Geol. Survey of Hyoming, Public Information Circular no. 4, 21 p.

Gow, K., 1950, Douglas Creek gas field: Intermountain Assoc. of Petroleum Geologists Guidebook to the Geology of Utah No. 5, p. 139-146.

Hackley, R.C., 1984, sulfur isotope variations in low-sulfur coals from the Rocky Mountain region: M.S. thesis, University of Illinois, $84 \mathrm{p}$.

Hale, L.A., 1950, Stratigraphy of the Upper Cretaceous Montana Group in the Rock Springs Uplift, Sweetwater County, Wyoming: M.A. thesis, University of Wyoming, $115 \mathrm{p}$.

1955. Stratigraphy and facies relationship of the Montanan Group in south central Wyoming, northeastern Utah, and northwestern Colorado: Wyoming Geol. Assoc. Guidebook 10th Ann. Field Conf., p. 89-94.

Hayden, F.V., 1869, Third annual report of the U.S. Geological and Geographical survey of the Territories: Washington, p. 191 . 
1879, Eleventh annual report of the U.S. Geological and Geographical survey of the Territories: Washington.

Hendricks, M.L., 1983, Stratigraphy and tectonic history of the Mesaverde Group (Upper Cretaceous), east flank of the Rock springs Uplift, Sweetwater County, Wyoming: Ph.D. dissertation, Colorado School of Mines, Golden, Colorado, $213 \mathrm{p}$.

Horne, J.C., Ferm, J.C., Caruccio, F.T., and Baganz, B.P., 1978. Depositional models in coal exploration and mine planning in Appalachian region: Am. Assoc. Petroleum Geologists Bull., v. 62, p. 2379-2411.

Hunt, C.B., 1967, Physiography of the United states: San Francisco, W. H. Freeman and Co., 480 p.

Jackson, T.J., and Ethridge, F.G., 1979, Floodplain sequences of a fine-grained meander-belt system: the lower Wasatch and upper Fort Union Formations, central Powder River Basin, Wyoming (Abstract): Am. Assoc. Petroleum Geologists Bull., v. 63, p. 831-832.

Jacob, A.F., 1973, Depositional environments of Paleocene Tongue River Formation, western North Dakota: Am. Assoc. Petroleum Geologists Bull., v. 57, p. 1038-1052.

1975, Geology of the upper part of the Fort Union Group (Paleocene), Williston Basin, with reference to uranium: North Dakota Geol. Survey Report of Investigations No. $58,49 \mathrm{p}$.

Johnston, R.H., 1959, Geology of the northern Leucite Hills, Sweetwater County, Wyoming: M.A. thesis, University of Wyoming, $83 \mathrm{p}$.

Kaiser, W.R., 1974, Texas lignite: Near-surface and deep-basin resources: Bureau Econ. Geol., University of Texas, Austin, Report of Investigations $79,70 \mathrm{p}$.

Keith, R.E., 1965, Rock Springs and the Blair Formations on and adjacent to the Rock springs Uplift: Wyoming Geol. Assoc. Guidebook 19th Ann. Field Conf., p. 43-53.

Kirschbaum, M.A., 1986, Geologic map of the Kappes Canyon quadrangle, Sweetwater County, Wyoming: U.S. Geol. Survey Map GQ-1607, scale 1:24,000. 
Rnight, S.H., 1955, Review of the early geological explorations of the Green River Basin area, 1812-1879: Wyoming Geol. Assoc. Guidebook 10th Ann. Field Conf., p. 10-17.

Rottlowski, F.E., 1965, Measuring stratigraphic sections: New York, Holt, Rinehart and Winston, $253 \mathrm{p}$.

Land, C.B., Jr., 1972, Stratigraphy of Fox Hills Sandstone and associated formations, Rock Springs Uplift and Wamsutter Arch area, Sweetwater County, Wyoming: A shoreline-estuary sandstone model for the Late Cretaceous: Colorado School of Mines Quarterly v. 67 no. 2, $69 \mathrm{p}$.

Law, B.E., Bucurel-White, H., and Bader, J.W., 1983, Sedimentological aspects of stratigraphic correlations in the Upper Cretaceous Ericson Sandstone, Greater Green River Basin, wyoming, Colorado, and Utah (Abstract): Geol. Soc. America Rocky Mountain Section Program with Abstracts, p. 333 .

Leblanc Smith, G., and Eriksson, K.A., 1979, A fluvioglacial and glaciolacustrine deltaic depositional model for Permo-Carboniferous coals of the northeastern Karoo Basin, South Africa: Palaeogeography, Palaeoclimatology, Palaeoecology, v. 27, p. 67-84.

Lee, W.T., 1915, The overland route, with a side trip to Yellowstone Park: Part B of Guidebook of the Western United States: U. S. Geol. Survey Bull. 612 .

Levey, R.A., 1985, Depositional model for understanding geometry of Cretaceous coals: major coal seams, Rock Springs Formation, Green River Basin, Wyoming: Am. Assoc. Petroleum Geologists Bull., v. 69, p. 1359-1380.

Lewis, J.L., 1961, The stratigraphy and depositional history of the Almond Formation in the Great Divide Basin, Sweetwater County, Wyoming: Wyoming Geol. Assoc. Guidebook 16th Ann. Field Conf., p. 87-95.

Love, J.D., and Christiansen, A.C., 1985, Geologic map of Wyoming: U. S. Geol. Survey Map, scale 1:500,000.

Lovering, T.S., 1929, Geologic history of the Front Range, Colorado: Colorado Sci. Soc. Proc., v. 12 no. 4, p. 59-111. 
Madden, D.J., 1981, Geologic map and coal sections of the Point of Rocks quadrangle, Sweetwater County, Wyoming: U. S. Geol. Survey Open-File Report 81-869, scale $1: 24,000$.

McCabe, P.J., 1984, Depositional environments of coal and coal-bearing strata, in Rahmani, R.A., and Flores, R.M., eds., sedimentology of Coal and Coal-bearing sequences: International Assoc. of sedimentologists, spec. Pub., Volume 7, p. 13-42.

McPhater, D., and MacTiernan, B., 1983, Well-site geologist's handbook: Tulsa, Oklahoma, PennWell publishing, $77 \mathrm{p}$.

Meek, F.B., and Hayden, F.V., 1862, Descriptions of new fossils collected in Nebraska, by the exploring expedition under the command of Capt. Wm. F. Raynolds: Acad. Nat. Sci. Philadelphia Proc., v. 13, p. 432-435.

Miller, F.X., 1977, Biostratigraphic correlation of the Mesaverde Group in southwestern wyoming and northwestern Colorado: Rocky Mountain Assoc. of Geologists 1977 Symposium, p. 117-137.

Mogensen, P., 1959, Fort Union Formation, east flank of the Rock springs Uplift, Sweetwater County, Wyoming: M.A. thesis, University of Wyoming, $86 \mathrm{p}$.

Nace, R.L., 1936, summary of the late Cretaceous and early Tertiary stratigraphy of Wyoming: Wyoming Geol. Survey Bull. 26, 271 p.

1939, Geology of the northwest part of the Red Desert, Sweetwater and Fremont Counties, wyoming: Wyoming Geol. Survey Bull. 27, $51 \mathrm{p}$.

Neidel1, N.S., 1980, stratigraphic modeling and interpretation: geophysical principles and techniques: Am. Assoc. of Petroleum Geologists Cont. Education Course Notes, $145 \mathrm{p}$.

Nielsen, G.F., ed., 1984, Reystone coal industry manual: New York, McGraw-Hill, $1388 \mathrm{p}$.

Oriel, S.S., and Tracey, J.I., 1970, Uppermost Cretaceous and Tertiary stratigraphy of Fossil basin, Southwestern Wyoming: U. S. Geol. Survey Prof. Paper 635, 53 p. 
Picard, M.D., Bruhn, R.B., and Beck, S.L., 1983, Mesozoic and early Tertiary paleostructure and sedimentology of Central Wasatch Mountains, Uinta Mountains, and Uinta Basin (Abstract): Am. Assoc. Petroleum Geologists Bull., v. 67, p. 1351-1352.

Pipiringos, G.N., 1955, Tertiary rocks in the central part of the Great Divide Basin, Sweetwater County, Wyoming: Wyoming Geol. Assoc. Guidebook loth Ann. Field Conf., p. 100-104.

Randall, A.G., 1961, Catalog of formation names for PostNiobrara Pre-Eocene Rocks of Wyoming and adjacent areas: Wyoming Geol. Assoc. Guidebook 16th Ann. Field Conf., p. 9-15.

Ritzma, H.R., 1955, Late Cretaceous and early Cenozoic structural pattern, southern Rock Springs Uplift, Wyoming: Wyoming Geol. Assoc. Guidebook 10 th Ann. Field Conf., p. 135-137.

' 1965, Fossil soil at base of Paleocene rocks, southern Rock Springs Uplift, Wyoming: Wyoming Geol. Assoc. Guidebook 19th Ann. Field Conf., p. 10-12.

Roehler, H.W., 1961, The Late Cretaceous-Tertiary boundary in the Rock Springs Uplift, Sweetwater County, Wyoming: Wyoming Geol. Assoc. Guidebook 16 th Ann. Field Conf., P. 96-100.

, 1965, Summary of pre-Laramide Late Cretaceous sedimentation in the Rock springs Uplift area: Wyoming Geol. Assoc. Guidebook 19th Ann. Field Conf. p. 11-12.

1977, Geologic map of the Rock Springs Uplift and adjacent areas, Sweetwater County, Wyoming: U. S. Geol. Survey Open-File Report 77-242, scale 1:125,000.

1979a, Geology and energy resources of the Sand Butte Rim NW Quadrangle, Sweetwater County, Wyoming: U. S. Geol. Survey Prof. Paper 1065-A, 54 p.

1979b, Geology of the Cooper Ridge NE Quadrangle, Sweetwater County, Wyoming: U. S. Geol. Survey Prof. Paper 1065-B, 45 p.

- 1979c, Geology and mineral resources of the Mud Springs Ranch Quadrangle, Sweetwater County, Wyoming: U. S. Geol. Survey Prof. Paper 1065-C, 35 p. 
Root, F.R., Glass, G.B., and Lane, D.W., 1973, Sweetwater County, Wyoming, geologic map atlas and summary of economic mineral resources: Geol. Survey of Wyoming County Resource series No. 2 .

Royse, C.F., Jr., 1970, A sedimentological analysis of the Tongue River-Sentinel Butte interval (Paleocene) of the Williston Basin, western North Dakota: Sed. GeologY, V. 4, p. 19-80.

Schultz, A.R., 1909, The northern part of the Rock springs coal field, Sweetwater county, wyoming in coal fields of Wyoming: U. S. Geol. Survey Bull. 341-B, pt. 2, p. 256-282.

, 1910, The southern part of the Rock springs coal field, sweetwater County, Wyoming, in Coal fields of Wyoming: U. S. Geol. Survey Bull. 381, pt. 2, p. 214281 .

, 1920, Oil possibilities in and around the Baxter Basin, in the Rock springs Uplift, sweetwater county, Wyoming: U. S. Geol. Survey Bull. 702, 107 p.

Sears, J.D., and Bradley, W.H., 1925, Relations of the Wasatch and Green River Formations in northwest Colorado and southern Wyoming: U. S. Geol. Survey Prof. Paper 132-F, p. 93-107.

Severn, W.P., 1959, stratigraphy of late Upper Cretaceous, Paleocene, and early Eocene deposits within the east flank of the Rock springs Uplift, Sweetwater County, Wyoming: M.A. thesis, University of Wyoming, $90 \mathrm{p}$.

Sharp, W.N., and Gibbons, A.B., 1964, Geology and uranium deposits of the southern part of the Powder River $\mathrm{Ba}-$ sin, Wyoming: U.S. Geol. Survey Bull. 1147-D, 59 p.

Smith, D.G., and Putnam, P.E., 1980, Anastomosed river deposits: Modern and ancient examples in Alberta, Canada: Canadian Journal of Earth Sciences, v. 17, p. 1396-1406.

Smith, D.G., and Smith, N.D., 1980, sedimentation in anastomosed river systems: Examples from alluvial valleys near Banff, Alberta: Journal of Sedimentary Petrology, v. 50, p. 157-164. 
Smith, J.H., 1965, A summary of stratigraphy and paleontology, Upper Colorado and Montana Groups, south central wyoming, northeastern Utah, and northwestern Colorado: Wyoming Geol. Assoc. Guidebook 19 th Ann. Field Conf., p. 13-25.

Smithson, S.B., 1959, The geology of the southeastern Leucite Hills, Sweetwater County, Wyoming: M.A. thesis, University of Wyoming, $92 \mathrm{p}$.

Sullivan, R., 1985, Origin of lacustrine rocks of Wilkins Peak Member, Wyoming: Am. Assoc. Petroleum Geologists Bull. v. 69, p. 913-922.

Swain, B.W., 1957, Fort Union Formation, west flank of the Sierra Madre, Carbon County, Wyoming: M.A. thesis, University of Wyoming, $132 \mathrm{p}$.

Thrush, P.w., comp, 1968, A dictionary of mining, mineral, and related terms, compiled and edited by Paul W. Thrush and the staff of the Bureau of Mines: U.S. Dept. of the Interior, Bureau of Mines, $1269 \mathrm{p}$.

Wanless, H.R., Baroffio, J.R., and Trescott, P.C., 1969, Conditions of deposition of Pennsylvanian coal beds, in Dapples, E.C., and Hopkins, M.E., eds., Environments of Coal Deposition: Geol. Soc. America Special Paper No. 114, p. 105-142.

Ward, C.R., ed., 1984, Coal geology and coal technology: Carlton, Victoria, Australia, Blackwell scientific Publications, $345 \mathrm{p}$.

Weimer, R.J., 1970, Rates of deltaic sedimentation and intrabasin deformation, Upper Cretaceous of Rocky Mountain region, in Morgan, J.P., ed., Deltaic Sedimentation, Modern and Ancient: Soc. Econ. Paleon. and Mineralog. Spec. Pub. 15, p. 270-292.

Welder, G.E., and McGreevy, L.J., 1966, Ground-water reconnaissance of the Great Divide and Washakie Basins and some adjacent areas, southwestern Wyoming: U. S. Geol. Survey Hydrologic Investigations Atlas HA-219, sh. 1 , scale $1: 250,000$.

Wing, S.L., 1984, Relation of paleovegetation to geometry and cyclicity of some fluvial carbonaceous deposits: Journal of Sedimentary petrology, v. 54, p. 52-66. 
APPENDIX 1

MEASURED SURFACE SECTIONS 
MASTER DATASET

JIH BRIOGER COAL FIELD

MEASURED SECTIOU: MS86001

\begin{tabular}{|c|c|c|c|c|c|c|}
\hline $\begin{array}{l}\text { NORTH } \quad 39 \\
\text { EAST } 51 \\
\text { ELEYATION: } \\
\text { COHIENTS: }\end{array}$ & $\begin{array}{l}93468 \\
14097 \\
\quad 6857.6\end{array}$ & $\begin{array}{l}\text { SECTION } 35 \\
\text { TOUNSH IP: } 21 \mathrm{~N} \\
\text { RANGE: IOWU }\end{array}$ & $\begin{array}{l}\text { COORDINATE SYSTEN: SP } \\
\text { SURVEY/EST: S } \\
\text { CONF IDENCE: } 11\end{array}$ & $\begin{array}{l}\text { HINING COAPANY : BCC } \\
\text { CONTAACTOR: } \\
\text { FIELD REP: PSH }\end{array}$ & $\begin{array}{l}\text { YEAR: } 86 \\
\text { TOTAL DEPTH: } 45 \\
\text { SECTION TYPE: SU } \\
\text { GEOPHYSICAL LOGS: }\end{array}$ & \\
\hline $\begin{array}{l}\text { OP DEPTH } \\
=======\end{array}$ & $\begin{array}{l}\text { BOTTON DEPTH } \\
==\approx==\approx=====\end{array}$ & $\begin{array}{l}\text { LITH } \\
== \pm====== \pm=\end{array}$ & 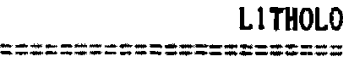 & 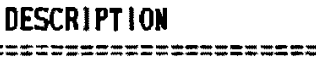 & 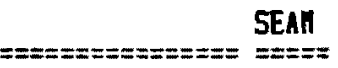 & $\begin{array}{l}\text { NOTE } \\
== \pm=\end{array}$ \\
\hline
\end{tabular}

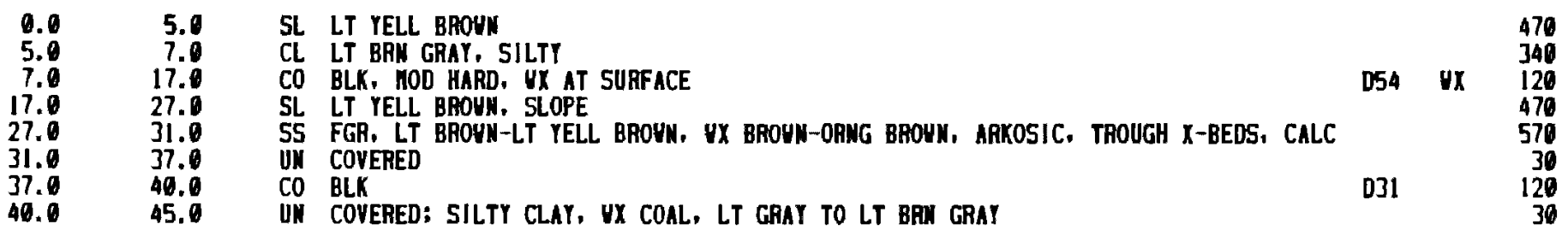

MEASURED SECTION: HS86002

\begin{tabular}{|c|c|c|c|c|c|c|c|c|}
\hline $\begin{array}{l}\text { NORTH } \quad 39 \\
\text { EAST } 51 \\
\text { ELEVATION: } \\
\text { COMHENTS: }\end{array}$ & $\begin{array}{l}93346 \\
14419 \\
\quad 6823.2\end{array}$ & $\begin{array}{l}\text { SECTION } 35 \\
\text { TOUNSHIP: } 21 \mathrm{~N} \\
\text { RANGE: } 100 \mathrm{~N}\end{array}$ & $\begin{array}{l}\text { COORDINATE SYSTEK: SP } \\
\text { SURVEY/EST: S } \\
\text { CONFIDENCE: II }\end{array}$ & $\begin{array}{l}\text { HINING COHPAIY: BCC } \\
\text { CONTRACTOR: } \\
\text { FIELD REP: PSK }\end{array}$ & $\begin{array}{l}\text { YEAR: B6 } \\
\text { TOTAL DEPTH: } \\
\text { SECTION TYPE: SI } \\
\text { GEOPHYSICAL LOGS }\end{array}$ & 21 & & \\
\hline $\begin{array}{l}\text { TOP DEPTH } \\
==== \pm===\end{array}$ & $\begin{array}{l}\text { BOTTOH DEPTH } \\
======== \pm=\end{array}$ & $\begin{array}{l}\text { LITH } \\
== \pm===== \pm=0\end{array}$ & 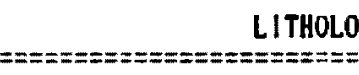 & 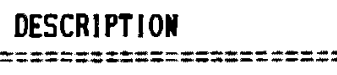 & 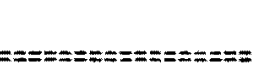 & $\underset{== \pm==}{\text { SEAh }}$ & $\begin{array}{l}\text { NOTE } \\
== \pm==\end{array}$ & $\begin{array}{l}\text { CODE } \\
====\end{array}$ \\
\hline $\begin{array}{r}0.0 \\
11.5 \\
11.0\end{array}$ & $\begin{array}{l}1.5 \\
11.0 \\
21.0\end{array}$ & $\begin{array}{ll}\text { SL } & \text { BROYN UX } \\
\text { CO } & \text { BLX, SOF } \\
\text { CL LT GRAY, }\end{array}$ & $\begin{array}{l}\text { BRN GRAT } \\
\text { UX, } V \text { VX } 9.0-11.0 \\
\text { LTY }\end{array}$ & & & D54 & VX & $\begin{array}{l}440 \\
130 \\
330\end{array}$ \\
\hline
\end{tabular}


MEASURED SECTION: MSB6903

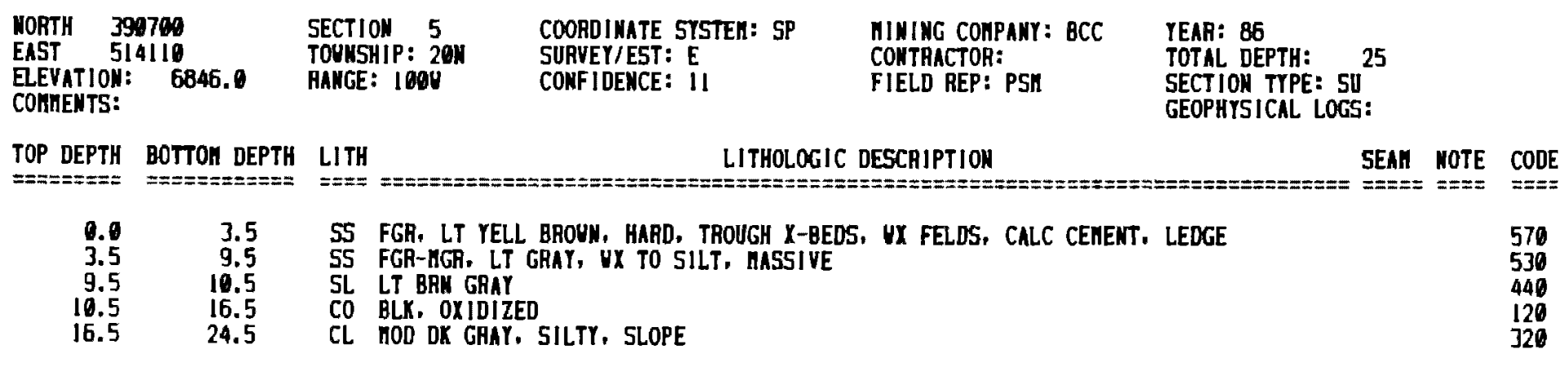

MEASURED SECTIOH: MSB6004

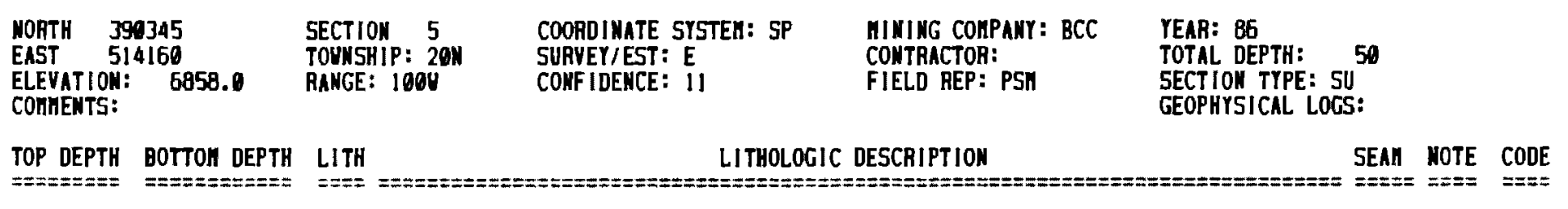

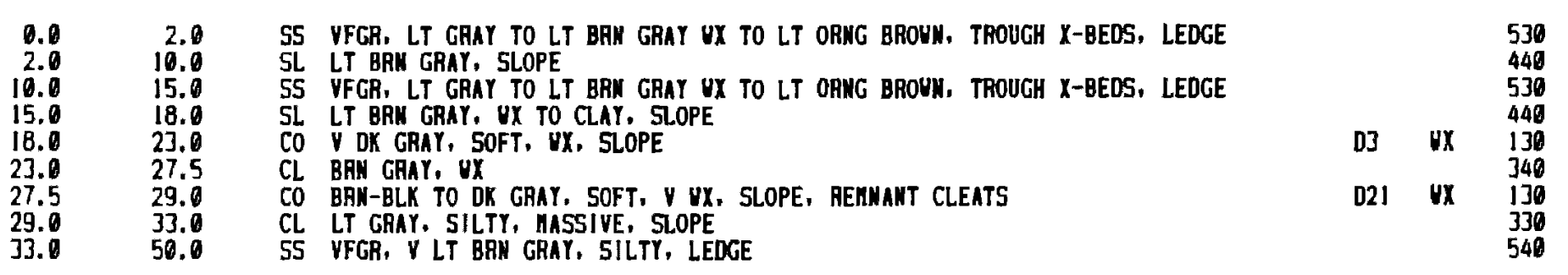


MEASURED SECTION: MS86095

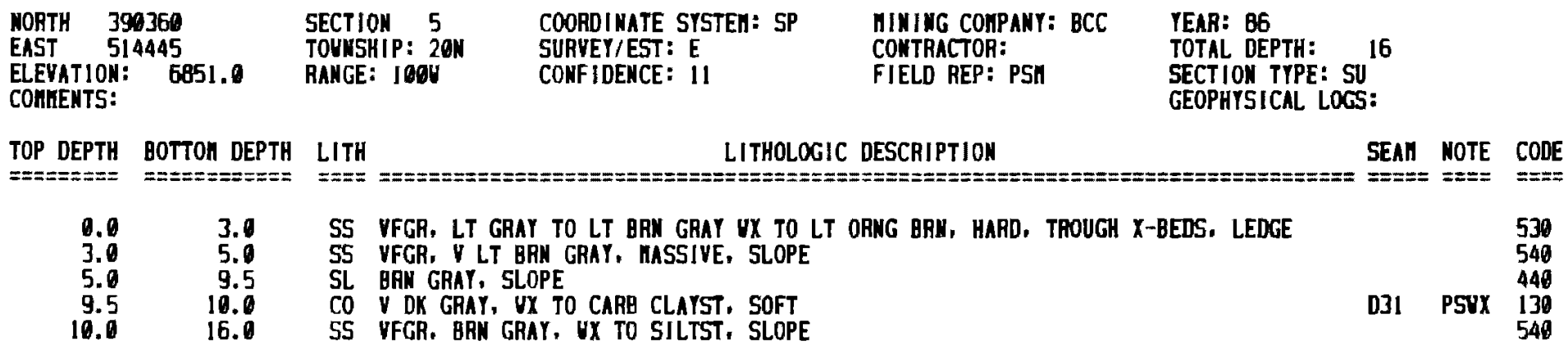

MEASURED SECTION: MSB6066

\begin{tabular}{|c|c|c|c|c|c|c|c|}
\hline $\begin{array}{l}\text { NORTH } \\
\text { EAST } \\
\text { ELEVATIOI } \\
\text { CONHENTS }\end{array}$ & $\begin{array}{l}389880 \\
514875 \\
7 N: \quad 6858.0\end{array}$ & $\begin{array}{l}\text { SECTION } \quad 5 \\
\text { TOUNSHIP: } 20 \mathrm{~N} \\
\text { RAHGE: } 100 \mathrm{~S}\end{array}$ & $\begin{array}{l}\text { COORDINATE SYSTEH: SP } \\
\text { SURYEY/EST: E } \\
\text { CONFIDENCE: I1 }\end{array}$ & $\begin{array}{l}\text { NINING CONPANY: BCC } \\
\text { CONTRACTOR: } \\
\text { FIELD REP: PSH }\end{array}$ & $\begin{array}{l}\text { YEAH: B6 } \\
\text { TOTAL DEPTH: } 24 \\
\text { SECTION TYPE: SU } \\
\text { GEOPHYSICAL LOCS: }\end{array}$ & & \\
\hline $\begin{array}{l}\text { TOP DEPTI } \\
== \pm== \pm=\end{array}$ & $\begin{array}{l}\text { BOTTOH DEPTH } \\
==========\end{array}$ & $\begin{array}{l}\text { LITH } \\
===========8\end{array}$ & 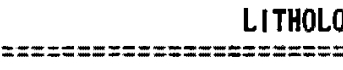 & $\begin{array}{l}\text { ESCRIPTIOU } \\
:====== \pm== \pm= \pm=== \pm=\end{array}$ & 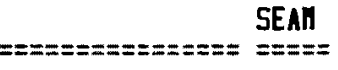 & $\begin{array}{l}\text { NOTE } \\
====\end{array}$ & $\begin{array}{l}\mathrm{CODE} \\
====\end{array}$ \\
\hline
\end{tabular}

\begin{tabular}{|c|c|c|c|c|c|}
\hline $\begin{array}{l}0.0 \\
1.0 \\
7.9 \\
8.3 \\
8.8 \\
12.5 \\
15.5\end{array}$ & $\begin{array}{r}1.0 \\
7.9 \\
8.3 \\
8.8 \\
12.5 \\
15.5 \\
24.0\end{array}$ & $\begin{array}{l}\text { SS } \\
\text { SS } \\
\text { CL } \\
\text { CL } \\
\text { CO } \\
\text { CL } \\
\text { SL }\end{array}$ & $\begin{array}{l}\text { FGR, Y LT GRN GRAY UX OANG BROUN, NOD IND, Y SORTED. LEDGE } \\
\text { YFGR, LT YELL BRN, GYPS, UX TO SILTST, LEDGE } \\
\text { LT YELL GRAY. LEDGE } \\
\text { LT RED GRAY, LEDGE } \\
\text { BLK, SOFT, DULL TO NOD BRIGHT, PYR (UX), UELL DEYELOPED CLEATING } \\
\text { LT GRAY, SILTY, SLOPE } \\
\text { BRN GRAY, SLOPE, UX TO CLAY }\end{array}$ & 031 & PSUX \\
\hline
\end{tabular}


MERSURED SECTION: MS86007

\begin{tabular}{|c|c|c|c|c|c|c|c|c|}
\hline $\begin{array}{l}\text { NORTH } 36 \\
\text { EAST } 51 \\
\text { ELEVAT ION: } \\
\text { CONHENTS: }\end{array}$ & $\begin{array}{l}389570 \\
515028 \\
: \quad 6870.0\end{array}$ & $\begin{array}{l}\text { SECTION } 4 \\
\text { TOUNSHIP: } 20 \mathrm{~N} \\
\text { RANGE: } 100 \mathrm{~N}\end{array}$ & $\begin{array}{l}\text { COORDIYATE SYSTEH: SP } \\
\text { SURVEY/EST: E } \\
\text { CONFIDENCE: } 11\end{array}$ & $\begin{array}{l}\text { MINIMG COAPANY: BCC } \\
\text { CONTAACTOR: } \\
\text { FIELD REP: PSH }\end{array}$ & $\begin{array}{l}\text { TEAR: } 86 \\
\text { TOTAL DEPTH: } \\
\text { SECTION TYPE: SL } \\
\text { GEOPHTSICAL LOC: }\end{array}$ & & & \\
\hline $\begin{array}{l}\text { TOP DEPTH } \\
=======\end{array}$ & $\begin{array}{l}\text { BOTTOH DEPTH } \\
== \pm=== \pm==\end{array}$ & 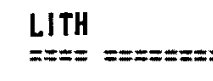 & $======z======== \pm====-=$ & $\begin{array}{l}\text { DESCRIPTION } \\
===:===============\end{array}$ & 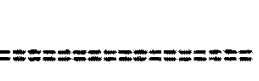 & SEAR & $== \pm$ & $\begin{array}{l}\mathrm{CODE} \\
== \pm=\end{array}$ \\
\hline $\begin{array}{r}0.0 \\
1.5 \\
9.6 \\
19.0 \\
14.5 \\
23.5\end{array}$ & $\begin{array}{r}1.5 \\
9.6 \\
10.0 \\
14.5 \\
23.5 \\
43.5\end{array}$ & $\begin{array}{l}\text { VFGR-FG } \\
\text { VFGR, V } \\
\text { LT PINK } \\
\text { BLK, SOI } \\
\text { LT GAAY } \\
\text { VFGR, V }\end{array}$ & 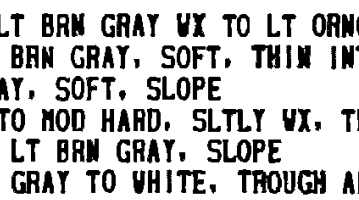 & $\begin{array}{l}\text { OWN, HARD, CALC CERENT } \\
\text { HARD STRGRS, RIP-UP CL } \\
\text { CLASTIC PTG, LEDCE } \\
\text { LAMAR X-BEDS, LEDGE TO }\end{array}$ & $\begin{array}{l}\text { LEDGE } \\
\text { TS FH ABOV, SLOPE } \\
\text { LOPE }\end{array}$ & D 11 & PSUX & $\begin{array}{l}540 \\
540 \\
330 \\
120 \\
430 \\
530\end{array}$ \\
\hline
\end{tabular}

MEASURED SECTION: ISB6908

\begin{tabular}{|c|c|c|c|c|}
\hline $\begin{array}{l}\text { NORTH } 389495 \\
\text { EAST } 514990 \\
\text { ELEVATION: } \quad 6881.6 \\
\text { COHIENTS: }\end{array}$ & $\begin{array}{l}\text { SECTION } \quad 4 \\
\text { TOUNSHIP: } 20 N \\
\text { RANGE: } 1004\end{array}$ & $\begin{array}{l}\text { COORDINATE STSTEH: SP } \\
\text { SURVET/EST: } \mathrm{S} \\
\text { CONFIDENCE: } 11\end{array}$ & $\begin{array}{l}\text { HINING COMPANY: BCC } \\
\text { CONTRACTOR: } \\
\text { FIELO REP: PSI }\end{array}$ & $\begin{array}{l}\text { IEAR: B6 } \\
\text { TOTAL DEPTH: } \\
\text { SECTION TTPE: SU } \\
\text { GEOPHYSICAL LOCS: }\end{array}$ \\
\hline
\end{tabular}

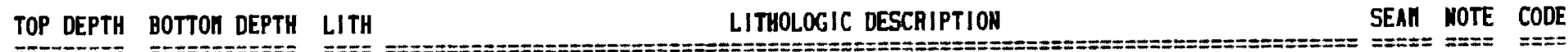

\begin{tabular}{|c|c|c|c|c|c|}
\hline $\begin{array}{r}0.0 \\
1.5 \\
9.5 \\
11.5 \\
16.0 \\
28.5 \\
29.5 \\
39.5\end{array}$ & $\begin{array}{r}1.5 \\
9.5 \\
11.5 \\
16.0 \\
28.5 \\
29.5 \\
39.5 \\
42.0 \\
59.5\end{array}$ & $\begin{array}{l}55 \\
\text { SS } \\
\text { CO } \\
\text { SL } \\
\text { SS } \\
\text { CL } \\
\text { SS } \\
\text { SS } \\
5 S\end{array}$ & 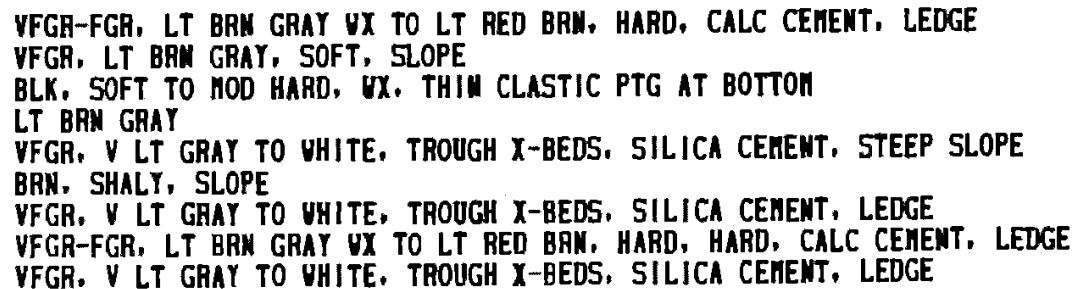 & D31 & PSUX \\
\hline
\end{tabular}


MEASURED SECTION: HS86009

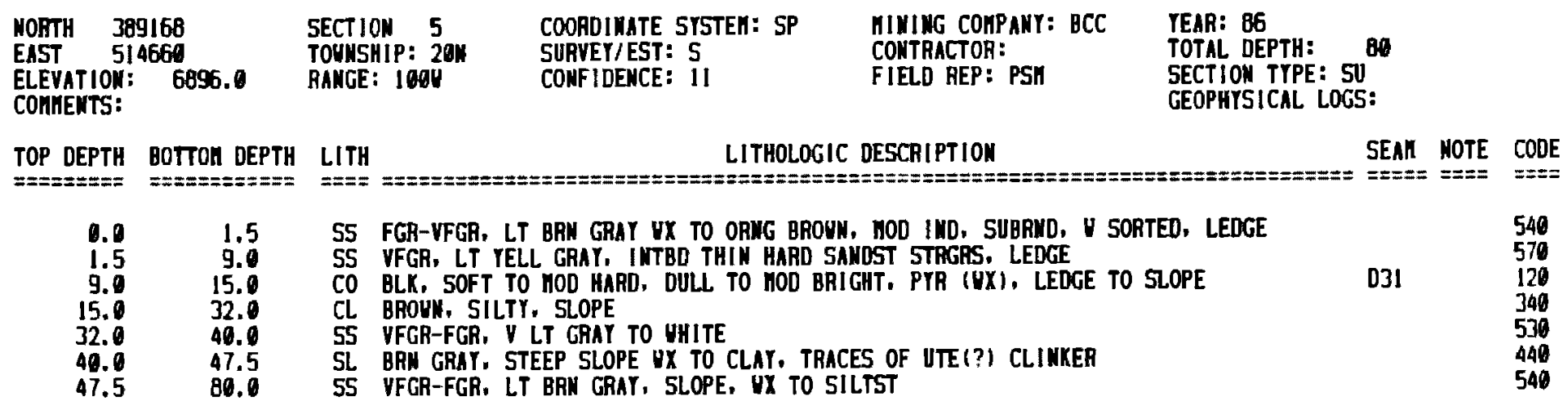

MEASURED SECTION: MS86010

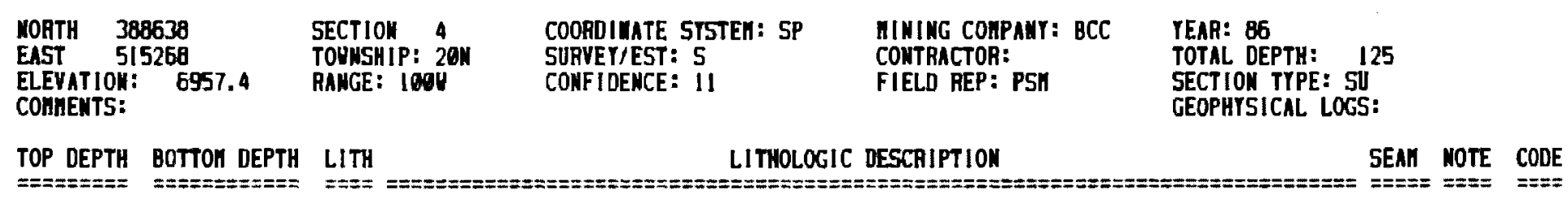

$\begin{array}{rr}0.0 & 11.0 \\ 11.0 & 29.0 \\ 29.0 & 29.5 \\ 29.5 & 51.0 \\ 51.0 & 53.0 \\ 53.0 & 58.0 \\ 58.0 & 68.0 \\ 68.0 & 71.1 \\ 71.1 & 71.5 \\ 71.5 & 75.0 \\ 75.0 & 94.0 \\ 94.0 & 116.8 \\ 116.8 & 117.0 \\ 117.0 & 119.5 \\ 119.5 & 120.9 \\ 120.9 & 121.4 \\ 121.4 & 122.5 \\ 122.5 & 125.0\end{array}$

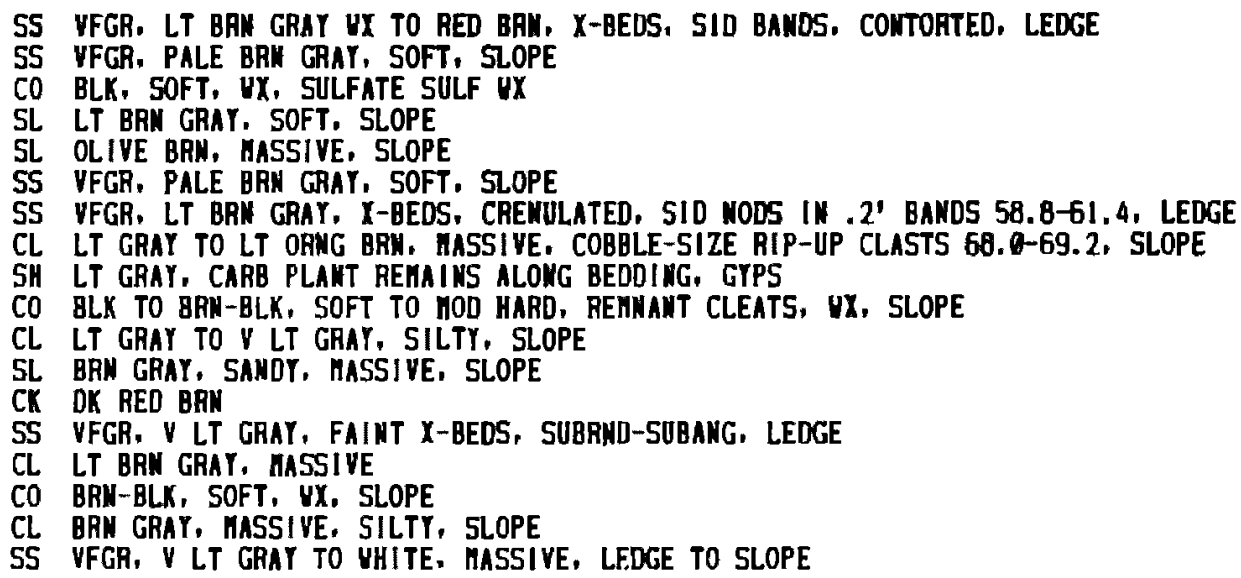


REASURED SECTION: MSB6011

\begin{tabular}{|c|c|c|c|c|c|c|c|}
\hline $\begin{array}{l}\text { AORTH } 38 \\
\text { EAST } 5 ! \\
\text { ELEVATION: } \\
\text { COHHENTS: }\end{array}$ & $\begin{array}{l}387964 \\
515169 \\
1: \quad 687.1\end{array}$ & $\begin{array}{l}\text { SECTION } 9 \\
\text { TOUNSHIP: } 20 \mathrm{~N} \\
\text { HANGE: } 100 \mathrm{~N}\end{array}$ & $\begin{array}{l}\text { COORDIMATE SYSTEN: SP } \\
\text { SURVEY/EST: } 5 \\
\text { CONFIDENCE: } 11\end{array}$ & $\begin{array}{l}\text { MINING COHPANY: BCC } \\
\text { CONTAACOOA: } \\
\text { FIELD REP: PSH }\end{array}$ & $\begin{array}{l}\text { TEAR: } 86 \\
\text { TOTAL DEPTH: } \\
\text { SECI ON TYPE: SU } \\
\text { GEOPHYSICAL, LOGS }\end{array}$ & $y^{8}$ & \\
\hline $\begin{array}{l}\text { TOP DEPTH } \\
==== \pm===\end{array}$ & $\begin{array}{l}\text { BOTTON DEPTH } \\
=== \pm===\end{array}$ & $\begin{array}{l}\text { L.ITH } \\
==========\end{array}$ & 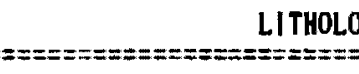 & 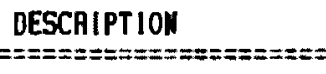 & & $\begin{array}{l}\text { 5EAII } \\
====\end{array}$ & $\begin{array}{l}\text { NOTE } \\
====\end{array}$ \\
\hline $\begin{array}{l}0.0 \\
2.8 \\
7.0\end{array}$ & $\begin{array}{l}2.8 \\
7.0 \\
7.5\end{array}$ & $\begin{array}{ll}\text { CG } & \text { LT BRN G } \\
\text { CO } & \text { BLK, HOD } \\
\text { SS } & \text { VFGR, LT }\end{array}$ & $\begin{array}{l}\text { SANDI MATRIX, P SOHT, } \\
\text { AD, DULL TO MOD BRIGHT, } \\
\text { GRAY, SOFT, SLOPE }\end{array}$ & $\begin{array}{l}\text { TS V AMG, LEDGE } \\
\text { DEVELOPED CLEATS, }\end{array}$ & G LEDGE & DJ1 & \\
\hline
\end{tabular}

MEASURED SECTION: MSB6012

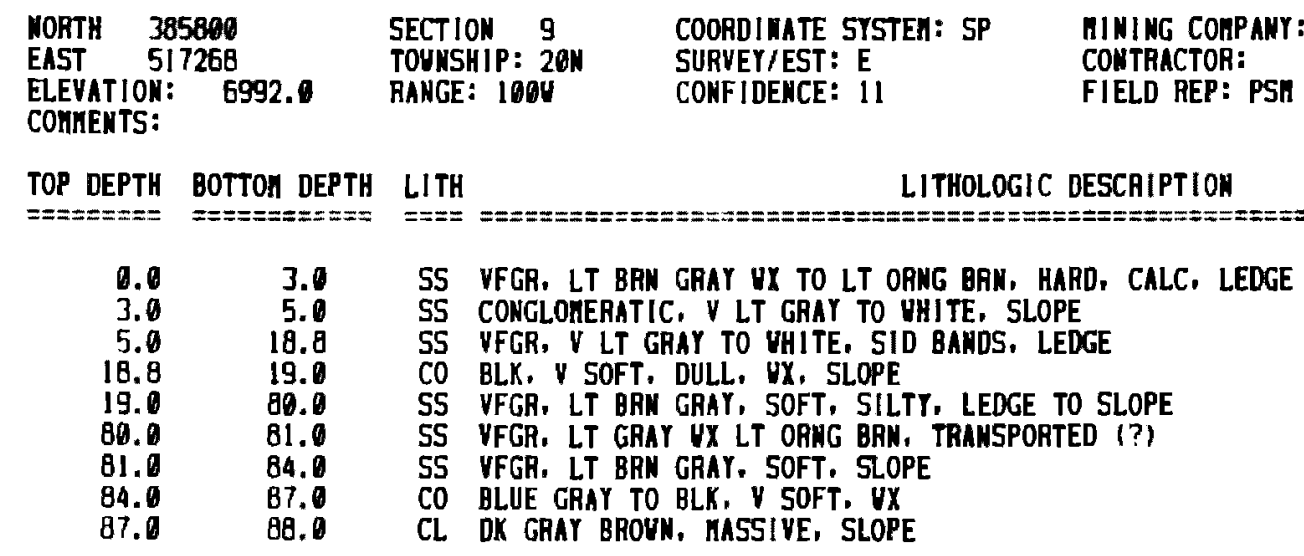

YEAR: 86

TOTAL. DEPTH: 88

SECTION TYPE: SU
GEOPHYSICAL LOGS: SEAH NOTE CODE

$\begin{array}{ccc} & & 540 \\ & & 530 \\ & 530 \\ \text { D54 } & \text { PSUX } & 130 \\ & & 540 \\ & & 530 \\ & & 540 \\ \text { DJI } & \text { PSUX } & 140 \\ & & 348\end{array}$


HEASURED SECTIOH: HSB6ø13

\begin{tabular}{|c|c|c|c|c|c|c|c|c|}
\hline $\begin{array}{lr}\text { NORTH } & 36 \\
\text { EAST } & 52 \\
\text { ELEVAT ION: } \\
\text { COHHENTS: }\end{array}$ & $6 \begin{array}{l}84382 \\
21614 \\
1: \quad 6878.0\end{array}$ & $\begin{array}{l}\text { SECTION } 10 \\
\text { TOHNSHIP: } 20 \mathrm{~N} \\
\text { RAHGE: } 1000\end{array}$ & $\begin{array}{l}\text { COOADIMATE 5YSTEH: SP } \\
\text { SURVEY/EST: E } \\
\text { CONFIDENCE: } 11\end{array}$ & $\begin{array}{l}\text { MINIMG COHPANY: BCC } \\
\text { CONTRACTOR: } \\
\text { FIELD REP: PSH }\end{array}$ & $\begin{array}{l}\text { YEAR: } 86 \\
\text { TOTAL DEPTH: } \\
\text { SECTION TYPE: SI } \\
\text { GEOPHYS ICAL LOGS }\end{array}$ & & & \\
\hline $\begin{array}{l}\text { TOP DEPTH } \\
== \pm== \pm==\end{array}$ & $\begin{array}{l}\text { BOTTOH DEPTH } \\
==========\end{array}$ & $\begin{array}{l}\text { LITH } \\
== \pm========8\end{array}$ & $==============$ LITHOLO & 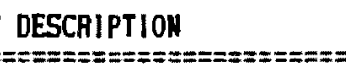 & 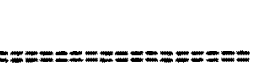 & SEAN & NOTE & $\stackrel{C O D E}{==-}$ \\
\hline $\begin{array}{r}0.0 \\
1.5 \\
8.5 \\
15.5 \\
17.5\end{array}$ & $\begin{array}{r}1.5 \\
8.5 \\
15.5 \\
17.5 \\
23.5\end{array}$ & $\begin{array}{l}\text { SS VFGR, LT } \\
\text { SL LT GRAY, } \\
\text { CO BLK TO BF } \\
\text { SL BAN GRAY, } \\
\text { SS VHITE TO }\end{array}$ & $\begin{array}{l}\text { GRAY UX TO BROWH, V VE } \\
\text { SSIVE, IRON BANDED } \\
\text { BLK, SOFT TO MOD HARD, } \\
\text { OFT, UX, SLOPE } \\
\text { LT GRAY, SILTY, HASSIVE, }\end{array}$ & $\begin{array}{l}\text { IND, CALC CEHENT, LEDGE } \\
\text { STEEP SLOPE } \\
\text {, SLOPE }\end{array}$ & & 054 & PSUX & $\begin{array}{l}540 \\
430 \\
130 \\
440 \\
530\end{array}$ \\
\hline
\end{tabular}

MEASUAED SECTION: M585014

$\begin{array}{lllll}\text { NORTH 383438 } & \text { SECTION 10 } & \text { COORDINATE SYSTEM: SP } & \text { MINING CONPANY: BCC } & \text { YEAR: 86 } \\ \text { EAST 524120 } & \text { TOUISHIP: 20N } & \text { SURVEY/EST: E } & \text { CONTRACTOR: } & \text { TOTAL DEPTH: } 50 \\ \text { ELEVATION: } 6869.0 & \text { RANGE: 100U } & \text { CONFIDEITE: } 11 & \text { FIELD REP: PSH } & \text { SECTION TYPE: SU } \\ \text { COMHENTS: } & & & & \text { GEOPHYSICAL LOGS: }\end{array}$

TOP DEPTH BOTTON DEPTH LITH LITHOLOCIC DESCRIPTION

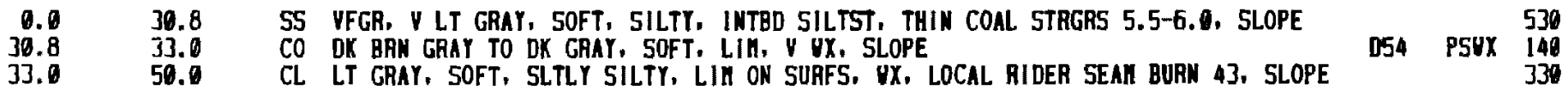


MEASURED SECT1ON: MS86015

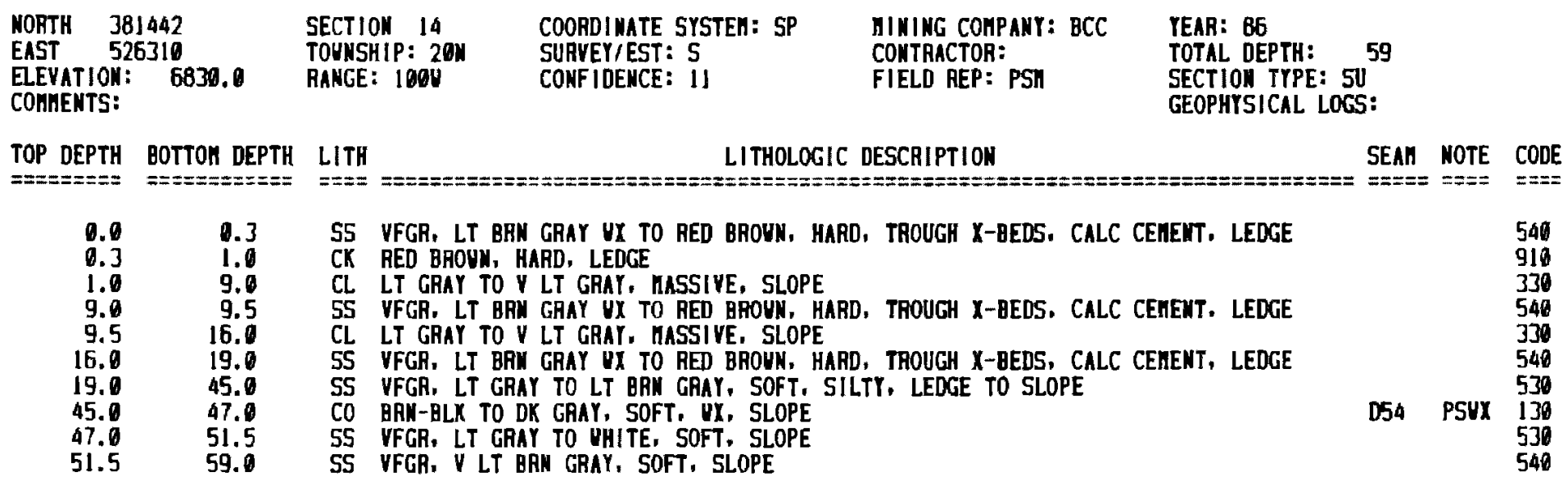

MEASURED SECTION: MSB6016

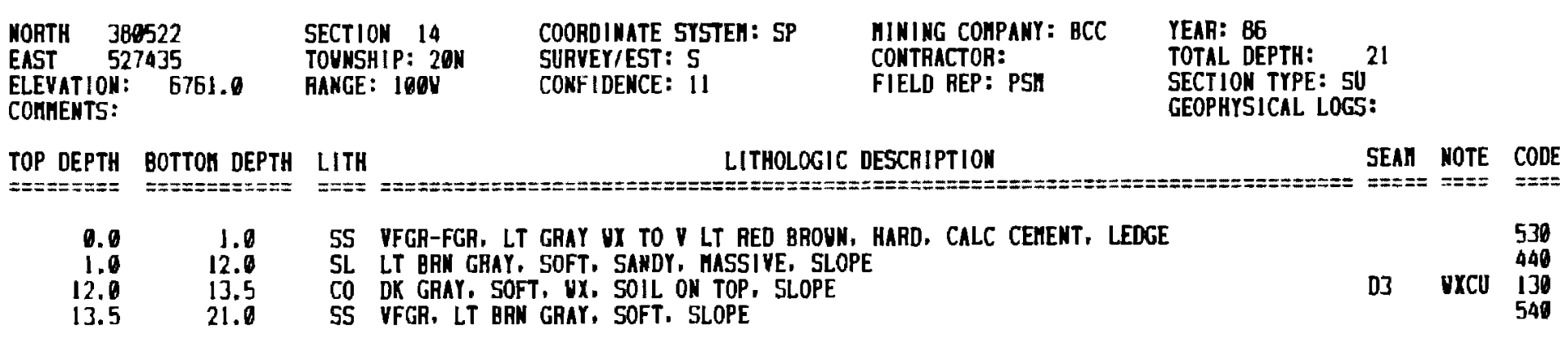


GEASURED SECTION: MSB6017

\begin{tabular}{|c|c|}
\hline $\begin{array}{l}\text { NORTH } \\
\text { EAST } \\
\text { ELEVATION: } \\
\text { COMMENTS: }\end{array}$ & $\begin{array}{l}3840 \\
5650 \\
6758.0\end{array}$ \\
\hline $\begin{array}{l}\text { TOP DEPTH } \\
========\end{array}$ & $\begin{array}{l}\text { BOTTOH DEPTH } \\
=\approx== \pm== \pm=\end{array}$ \\
\hline $\begin{array}{r}0.0 \\
8.0 \\
26.3 \\
27.0 \\
43.0 \\
46.0 \\
49.5 \\
55.5 \\
58.0 \\
63.0 \\
65.0\end{array}$ & $\begin{array}{r}8.0 \\
26.3 \\
27.0 \\
43.0 \\
46.0 \\
49.5 \\
55.5 \\
58.0 \\
63.0 \\
65.0 \\
80.0\end{array}$ \\
\hline
\end{tabular}

\section{SECTION 14 \\ TOUNSHIP: 20 N \\ RANGE: $100 \mathrm{~V}$}

COORDIHATE STSTER: SP

SURVEY/EST: 5

CONFIDENCE: II
HINING COHPAHY: BCC

CONTHACTOR:

FIELD REP: PSI
YEAR: 86

TOTAL DEPTH: 8

SECTION TYPE: SU

GEOPHYSICAL LOGS:

$$
\text { LITH }
$$

SS VFGR. LT BFN GRAY, SOFT, UX TO SILT, FAIRLY STEEP SLOPE

\section{(20)}

SS VFGR, UHITE TO V LT GRAY, HOD HARD, LEDGE

SL LT BROUH, CLAYEY

SS VFGR. UHITE TO V LT GRAY, MOD HARD, LEDGE

SS VFGR, LT BRI GRAY UI RED BROUH, HARD, FLAGGY, X-BEDS, CALC, LEDGE

SL V LT BRI GRAY, MASSIVE, CLAYEY, SLOPE

SS FGR. PINKISH GRAY TO V DK GRAY, HARD, STEEP SLOPE

SS VFGR, UHITE TO V LT GRAY, MOD HARD, LEDGE TO SLOPE

MEASURED SECTION: MS86018

\section{NORTH 3786I8 \\ EAST 529035 \\ ELEVATION: 6707. COHHENTS: \\ TOP DEPTH BOTTON DEPTH}

0.010 .0

$10.0 \quad 11.0$

$11.0 \quad 18.5$

$18.5 \quad 21.2$

$21.2 \quad 31.8$

$31.8 \quad 32$.

$32.0 \quad 35.0$

$35.0 \quad 38.5$

38.5
SECTION 14

TOUNSHIP: $20 \mathrm{~N}$

RANGE: 1000
COORDINATE SYSTEM: SP SURVEY/EST: $S$ CONFIDENCE: 11
MINIHG COMPAMY: BCC

CONTRACTOR:

FIELD HEP: PSI
IEAR: 86

TOTAL DEPTH: 40

SECTION TYPE: SU

GEOPHYSICAL LOGS:

SS VFGR, LT BRN GRAY, SOFT, MASSIVE, SLOPE

SS VFGR-FGR, LT YELL BROUN, TROUGH X-BEDS, CALCITE CENENT, I.EDGE

SL LT BRN GRAY. CLAYEY, UX

CO BLK, SOFT, UX, LIH, FACE GEATS

$5 S$ VFGR, LT BROUN, SOFT, SLOPE

$\mathrm{CL}$

CO BLK, UX, LIH, FACE CLEATS

SS VFGR, H'LT GAAY, SILTY

SS VFGR, M LT GAYY, SILTY
SS VFGR, UHITE TO LT BRN GRAY, MASSIVE, UX 
MEASURED SECTION: R5860/9

\begin{tabular}{|c|c|c|c|c|}
\hline $\begin{array}{l}\text { NORTH } 377152 \\
\text { EAST } 529789 \\
\text { ELEVATIOH: } \quad 6766.0 \\
\text { COHMENTS: }\end{array}$ & $\begin{array}{l}\text { SECTION } 23 \\
\text { TOUNSHIP: } 20 \mathrm{~N} \\
\text { RANGE: } 160 \mathrm{O}\end{array}$ & $\begin{array}{l}\text { COORDINATE SYSTEH: SP } \\
\text { SURVEY/EST: } 5 \\
\text { CONFIDENCE: } 11\end{array}$ & $\begin{array}{l}\text { MINING COHPAKY: BCC } \\
\text { CONTHACTOR: } \\
\text { FIELD REP: PSH }\end{array}$ & $\begin{array}{l}\text { YEAR: } 86 \\
\text { TOTAL DEPTH: } 35 \\
\text { SECTION TYPE: SU } \\
\text { GEOPHYSICAL LOGS: }\end{array}$ \\
\hline
\end{tabular}

TOP DEPTH BOTTOH DEPTH

LITH

LITHOLOGIC DESCRIPTION

SEAM NOTE CODE

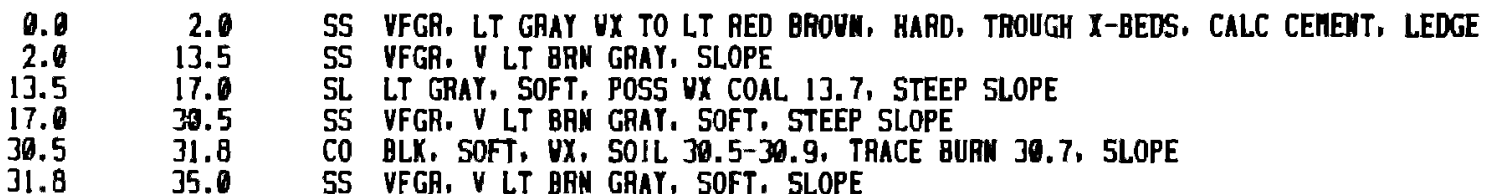

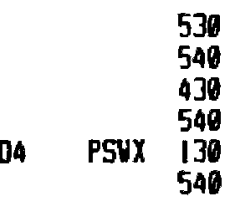

MEASURED SECTION: MS85020

\begin{tabular}{|c|c|c|c|c|}
\hline $\begin{array}{l}\text { NORTH } \quad 372520 \\
\text { EAST } \quad 526835 \\
\text { ELEVATION: } \quad 6854.0 \\
\text { COHKENTS: }\end{array}$ & $\begin{array}{l}\text { SECTION } 23 \\
\text { TOUHSHIP: } 29 \mathrm{~N} \\
\text { RAHGE: IOOU }\end{array}$ & $\begin{array}{l}\text { COORDINATE STSTEH: SP } \\
\text { SURVEY/EST: } \\
\text { CONFIDEMCE : } 11\end{array}$ & $\begin{array}{l}\text { HINING COHPANY: ECC } \\
\text { CONTRACTOR: } \\
\text { FIELD REP: PSH }\end{array}$ & $\begin{array}{l}\text { YEAH: B6 } \\
\text { TOTAL OEPTH: } 36 \\
\text { SECTION TYPE: SU } \\
\text { GEOPHYSICAL LOGS: }\end{array}$ \\
\hline
\end{tabular}

\begin{tabular}{|c|c|c|c|c|c|}
\hline $\begin{array}{l}\text { TOP DEPTH } \\
=== \pm====\end{array}$ & $\begin{array}{l}\text { BOTTON DEPTH } \\
===========\end{array}$ & $\begin{array}{l}\text { LITH } \\
====\end{array}$ & 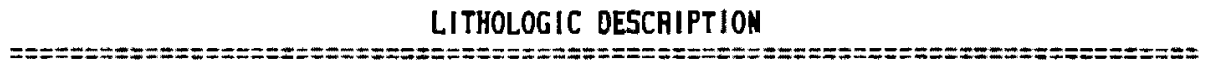 & $\begin{array}{l}\text { SEAn } \\
=====\end{array}$ & $\begin{array}{l}\text { NOTE } \\
====\end{array}$ \\
\hline $\begin{array}{l}0.0 \\
3.1 \\
16.0 \\
18.2 \\
30.7 \\
31.0\end{array}$ & $\begin{array}{l}3.1 \\
16.0 \\
18.2 \\
30.7 \\
31.0 \\
36.0\end{array}$ & $\begin{array}{l}\text { CK } \\
\text { SS } \\
\text { SS } \\
\text { SS } \\
\text { CO } \\
\text { SS }\end{array}$ & $\begin{array}{l}\text { DK RED BHOWN, FHACT, LEDGE } \\
\text { VFGR, LT BAN GRAY, UASSIVE, SOFT, SLOPE } \\
\text { VFGA, LT GAAY UX TO RED BHOUN, HARD, CALC CERENT, LEDGE } \\
\text { VFGR, Y LT GRAY TO UHITE, SOFT, SLOPE } \\
\text { BLK, SOFT, UX, SLOPE } \\
\text { VFGH, LT BAI GRAY, SOFT, HASSIYE, SLOPE }\end{array}$ & DJ1 & PSUX \\
\hline
\end{tabular}


HEASURED SECTION: HS86021

\begin{tabular}{|c|c|c|c|c|}
\hline $\begin{array}{l}\text { NOATH } 370725 \\
\text { EAST } 525340 \\
\text { ELEVATION: } \quad 6889.0 \\
\text { COHHENTS: }\end{array}$ & $\begin{array}{l}\text { SECTION } 26 \\
\text { TOUNSHIP: } 20 \mathrm{~N} \\
\text { RANGE: } 100 \mathrm{~N}\end{array}$ & $\begin{array}{l}\text { COORDIMATE SYSTEN: SP } \\
\text { SUREYY /EST: } \\
\text { COHFIDENCE: } 11\end{array}$ & $\begin{array}{l}\text { WINING COMPAYY: BCC } \\
\text { CONTRACTOA: } \\
\text { FIELD REP: PSH }\end{array}$ & $\begin{array}{l}\text { TEAR: } 86 \\
\text { TOTAL DEPTH: } \\
\text { SECTION TYPE: SU } \\
\text { GEOPHTSICAL LOGS: }\end{array}$ \\
\hline
\end{tabular}

TOP DEPTH BOTTOH DEPTH LITH

LITHOLOGIC DESCRIPTIOY

SEAM NOTE CODE

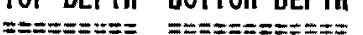

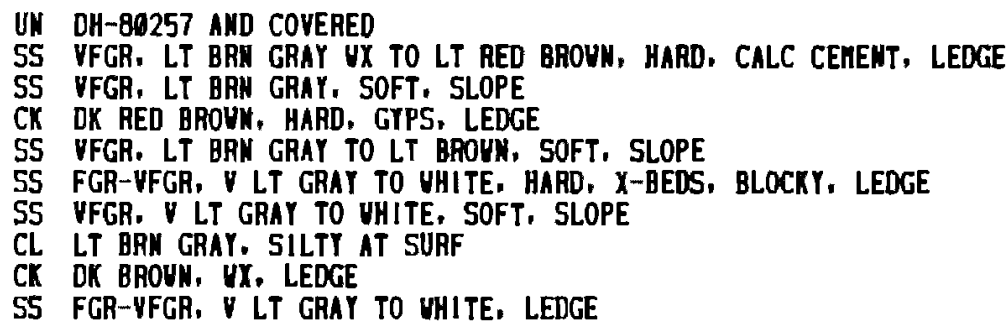

S5 FGR-VFGR, V LT GRAY TO VHITE, LEDGE

SECT10月 TYPE: SU

\begin{tabular}{|c|c|c|c|c|c|c|}
\hline $\begin{array}{r}0.0 \\
3.6 \\
5.0 \\
22.0 \\
26.5 \\
41.0 \\
55.0 \\
62.0 \\
67.2 \\
67.7\end{array}$ & $\begin{array}{r}3.6 \\
5.6 \\
22.0 \\
26.5 \\
41.0 \\
55.0 \\
62.0 \\
67.2 \\
67.3 \\
85.0\end{array}$ & $\begin{array}{l}\text { UN } \\
\text { SS } \\
\text { SS } \\
\text { CK } \\
\text { SS } \\
\text { SS } \\
\text { SS } \\
\text { CL } \\
\text { CK } \\
\text { SS }\end{array}$ & $\begin{array}{l}\text { DH-89257 AND COYERED } \\
\text { VFGR, LT BRN GRAY UX TO LT RED BROUN, HARD, } \\
\text { VFGR, LT BRN GRAY, SOFT, SLOPE } \\
\text { OK RED BROUN, HARD, GIPS, LEDGE } \\
\text { VFGR, LT BRN GRAY TO LT BROUN, SOFT, SLOPE } \\
\text { FGR-UFGR, V LT GRAY TO UHITE, HARD, X-BEOS, } \\
\text { UFGR, V LT GRAY TO UHITE, SOFT, SLOPE } \\
\text { LT BRN GRAY, SILTY AT SURF } \\
\text { OK BROUN, UX, LEDGE } \\
\text { FGR-VFGR, V LT GRAY TO UHITE, LEDGE }\end{array}$ & $\begin{array}{l}\text { CALC CERENT, LEDGE } \\
\text { BLOCKY, LEDGE }\end{array}$ & 031 & PSBU \\
\hline
\end{tabular}

MEASURED SECTION: MS86022

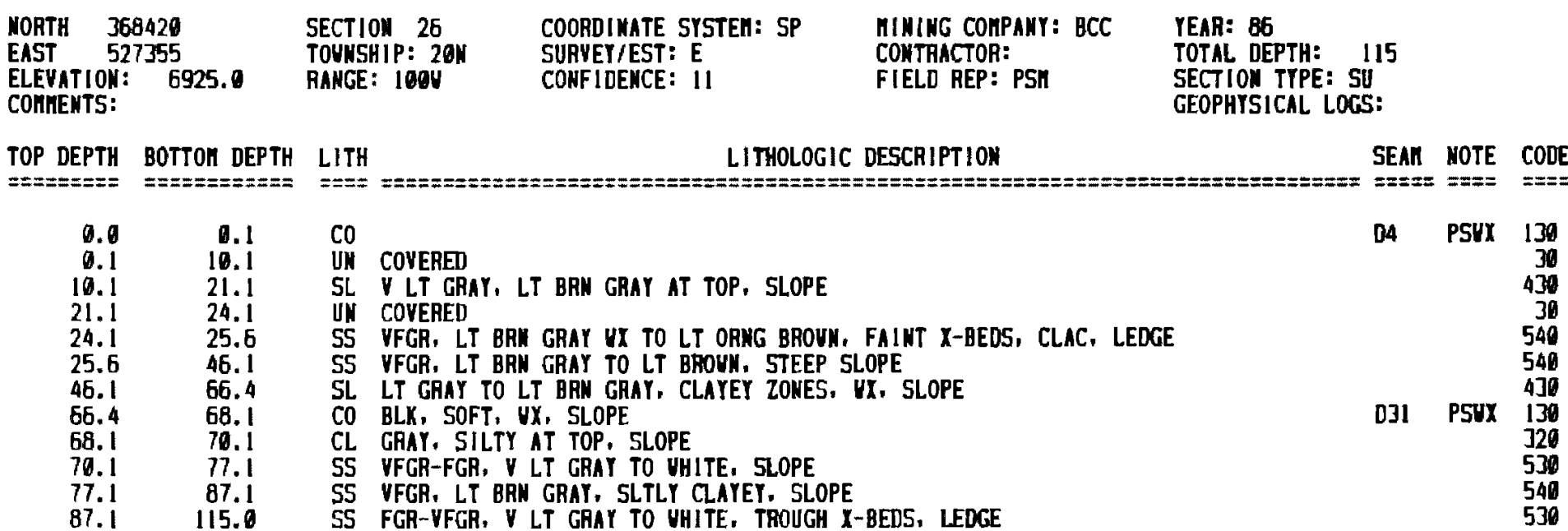


MEASURED SECTION: MSB6甲23

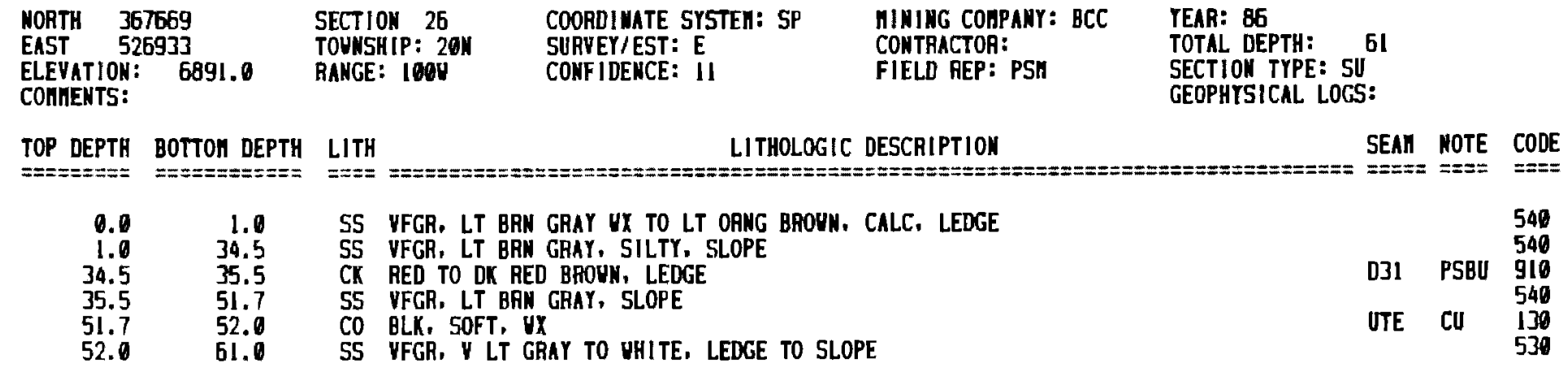

MEASURED SECTIOH: MS66024

\begin{tabular}{|c|c|c|c|c|c|c|c|}
\hline $\begin{array}{l}\text { NOBTH } \\
\text { EAST } \\
\text { ELEYATIOI } \\
\text { COHKENTS }\end{array}$ & $\begin{array}{l}366949 \\
527400 \\
3 N: \quad 6889.0\end{array}$ & $\begin{array}{l}\text { SECTION } 35 \\
\text { TOUNSHIP: } 20 \mathrm{~N} \\
\text { RANGE: I00V }\end{array}$ & $\begin{array}{l}\text { COORDINATE SYSTEH: SP } \\
\text { SURVEY/EST: E } \\
\text { CONFIDENCE: } 11\end{array}$ & $\begin{array}{l}\text { WINING COMPANY: BCC } \\
\text { CONTRACTOR: } \\
\text { FIELD REP: PSI }\end{array}$ & $\begin{array}{l}\text { IEAR: B5 } \\
\text { TOTAL DEPTH: } 49 \\
\text { SECTION TYPE: SU } \\
\text { GEOPHYSICAL LOGS: }\end{array}$ & & \\
\hline$=== \pm===0$ & $\begin{array}{l}\text { IH BOTTOH DEPTH } \\
======= \pm==z\end{array}$ & $\begin{array}{l}\text { LITH } \\
======= \pm=0\end{array}$ & 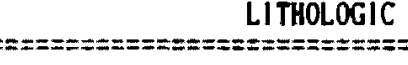 & 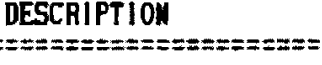 & 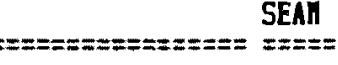 & $\begin{array}{l}\text { NOTE } \\
== \pm=\end{array}$ & $\begin{array}{l}\text { CODE } \\
====\end{array}$ \\
\hline
\end{tabular}

\begin{tabular}{|c|c|c|c|c|c|c|}
\hline $\begin{array}{r}0.0 \\
4.0 \\
7.0 \\
14.0 \\
16.0 \\
23.0 \\
24.0 \\
33.0 \\
38.0 \\
43.0 \\
46.0\end{array}$ & $\begin{array}{r}4.0 \\
7.0 \\
14.0 \\
16.0 \\
23.0 \\
24.0 \\
33.0 \\
38.0 \\
43.0 \\
46.0 \\
49.0\end{array}$ & $\begin{array}{l}\text { SS } \\
\text { S5 } \\
\text { SL } \\
\text { SS } \\
\text { CL } \\
\text { CO } \\
\text { SL } \\
\text { SL } \\
\text { SL } \\
\text { CL } \\
\text { SS }\end{array}$ & $\begin{array}{l}\text { VFGR, LT BAN GRAY, X-BEDDED, MASSIVE TO FLAGGY } \\
\text { LT GRAY TO ORANGE } \\
\text { BURNEO, INTBO CLINKER } \\
\text { LT BRN GAYY, CLAYEY, STEEP SLOPE } \\
\text { LT BROUN TO LT YELL BROUN UX TO LT RED BROUH, SAYDY, SLOPE } \\
\text { LT BRN GRAY, SANDY } \\
\text { GRAY TO LT GRAY, HASSIVE } \\
\text { VFGR, V LT GAAY, TROUGH X-BEDS, IRON STAINED } 48.8-49.0\end{array}$ & D31 & PSBU & $\begin{array}{l}500 \\
500 \\
400 \\
540 \\
330 \\
140 \\
440 \\
470 \\
440 \\
320 \\
530\end{array}$ \\
\hline
\end{tabular}


MEASURED SECTION: MS86025

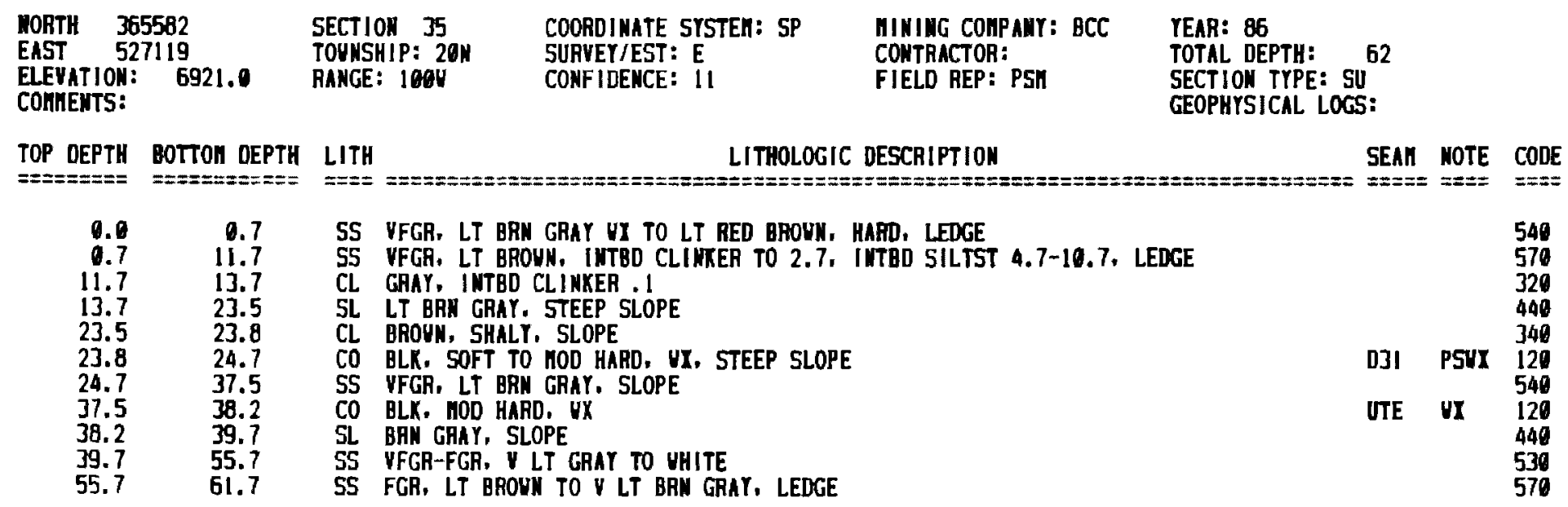

MEASURED SECTION: RSB6926

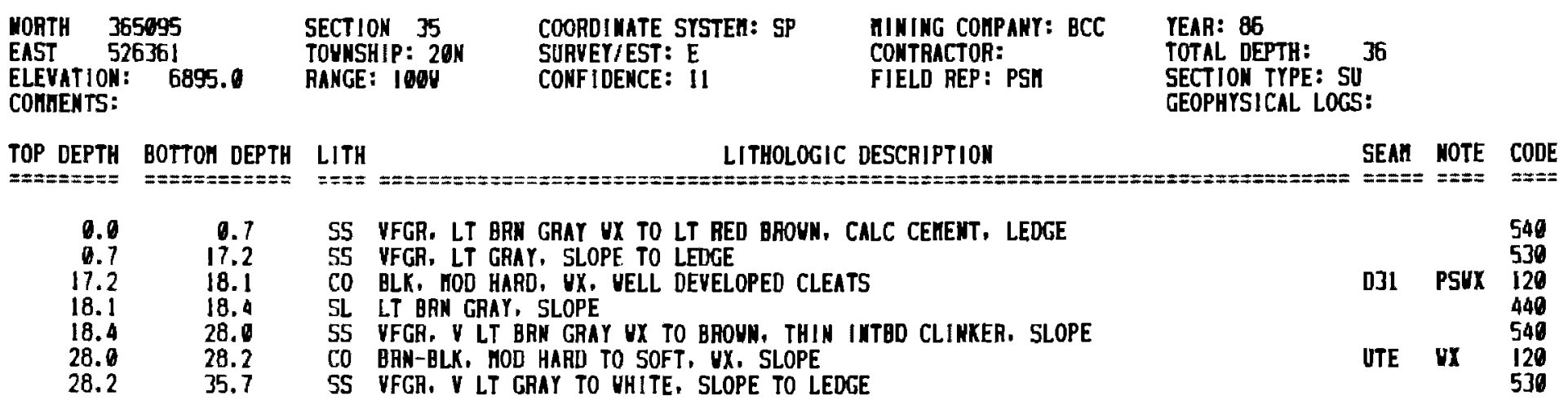


MEASURED SECTION: MS86927

\begin{tabular}{|c|c|c|c|c|}
\hline $\begin{array}{l}\text { NORTH } 364220 \\
\text { EAST } 526518 \\
\text { ELEVATION: } \quad 6928.0 \\
\text { COLIENTS: }\end{array}$ & $\begin{array}{l}\text { SECTION } 35 \\
\text { TOUNSHIP: } 20 \mathrm{~N} \\
\text { RANGE: IOGU }\end{array}$ & $\begin{array}{l}\text { COOROINATE SYSTEH: SP } \\
\text { SURVEY/EST: E } \\
\text { CONFIDENCE: } 11\end{array}$ & $\begin{array}{l}\text { RINING CORPANY: BCC } \\
\text { CONTRACTOR: } \\
\text { FIELO REP: PSI }\end{array}$ & $\begin{array}{l}\text { YEAR: B6 } \\
\text { TOTAL DEPTH: } 20 \\
\text { SECTION TYPE: SU } \\
\text { GEOPHYSICAL LOGS: }\end{array}$ \\
\hline
\end{tabular}

TOP DEPTH BOTTOH DEPTH LITH

LITHOLOGIC DESCRIPTION SEAH HOTE CODE

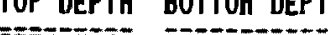

GEOPHYSICAL LOGS

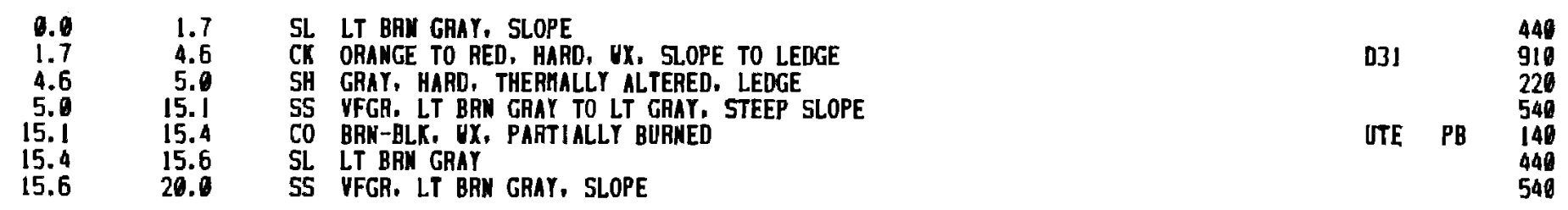

REASURED SECTION: ПSB6028

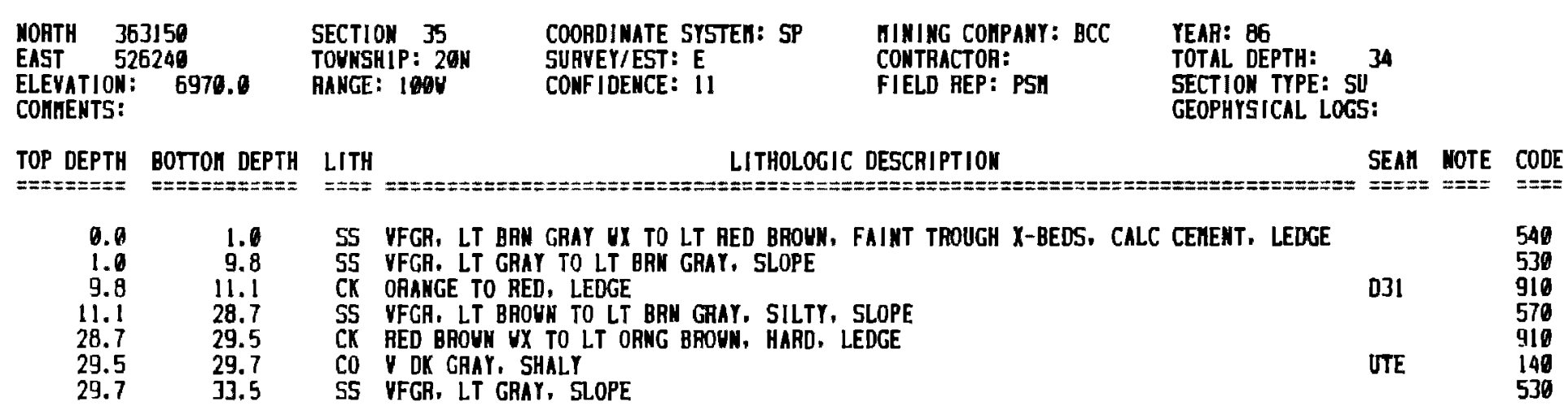


MEASURED SECTION: MS86029

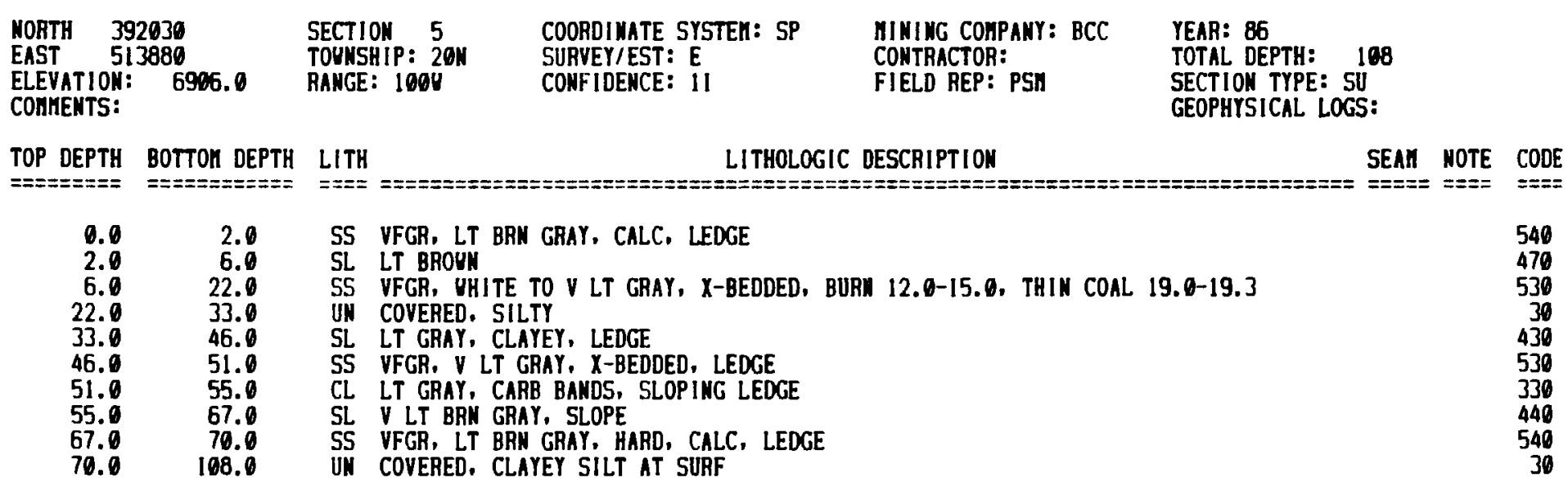




\section{APPENDIX 2}

SELECTED SUBSURFACE SECTIONS 
HASTER DATASET

JII BRIDGER COAL FIELD

DRILL HOLE NUMBER: $10110 B C$

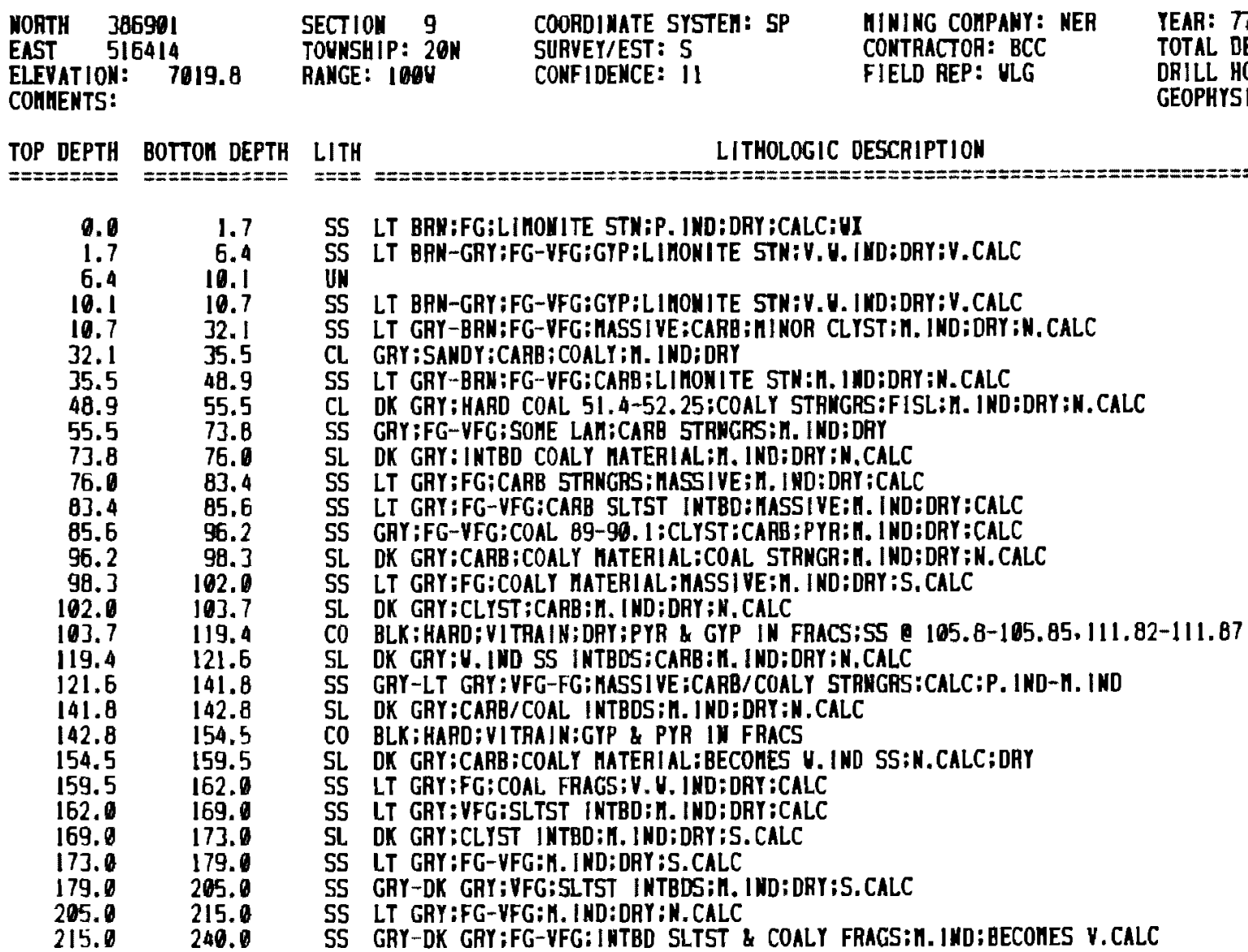

SS LT BRH-GRY:FG-VFG;GTP:LIHONITE STH:V.U. IYD;DRYiV.CALC

SS LT BRH-GRY:FG-YFGiGYP:LIMOUITE STM:Y. IYD:DRY:Y CALC

LT GRY-BRM:FG-VFG:MASSIVE:CABB IMINOR CLYST:M IND:DRY:H. CALC

$\begin{array}{cc} & 570 \\ & 540 \\ & 30 \\ & 540 \\ & 540 \\ & 330 \\ & 540 \\ & 320 \\ & 530 \\ & 420 \\ & 530 \\ & 530 \\ & 530 \\ & 420 \\ & 530 \\ & 420 \\ & 110 \\ & 420 \\ & 530 \\ & 420 \\ & 110 \\ & 420 \\ & 530 \\ & 530 \\ & 420 \\ & 530 \\ & 520 \\ & 530 \\ & 520\end{array}$

SL DK CRY:CARB:COALY AATERIAL:BECOHES U. IND SS:H.CALC:DHY 
DRILL HOLE NUMBEA: 10130BC

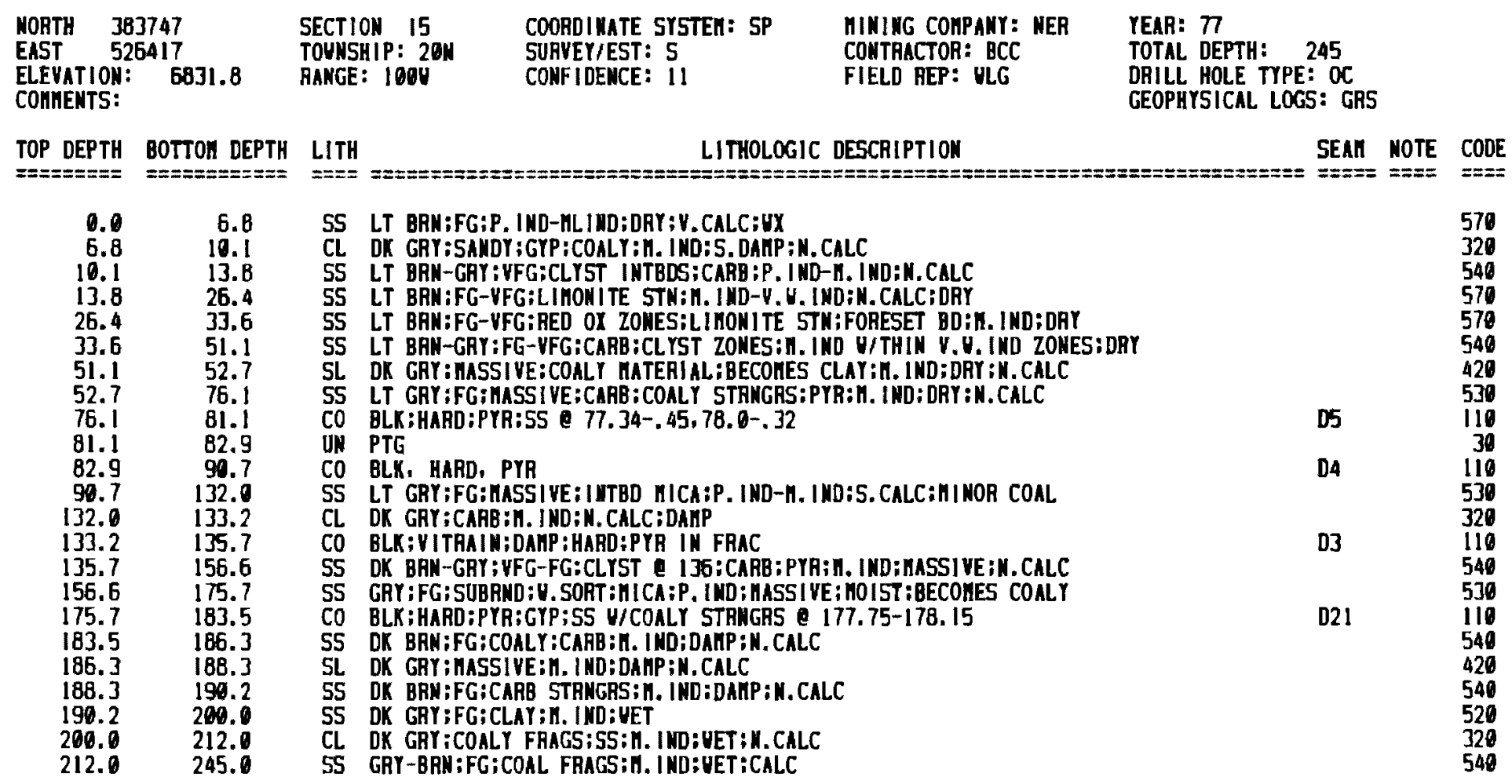


DRILL HOLE NUABER: 820170BC

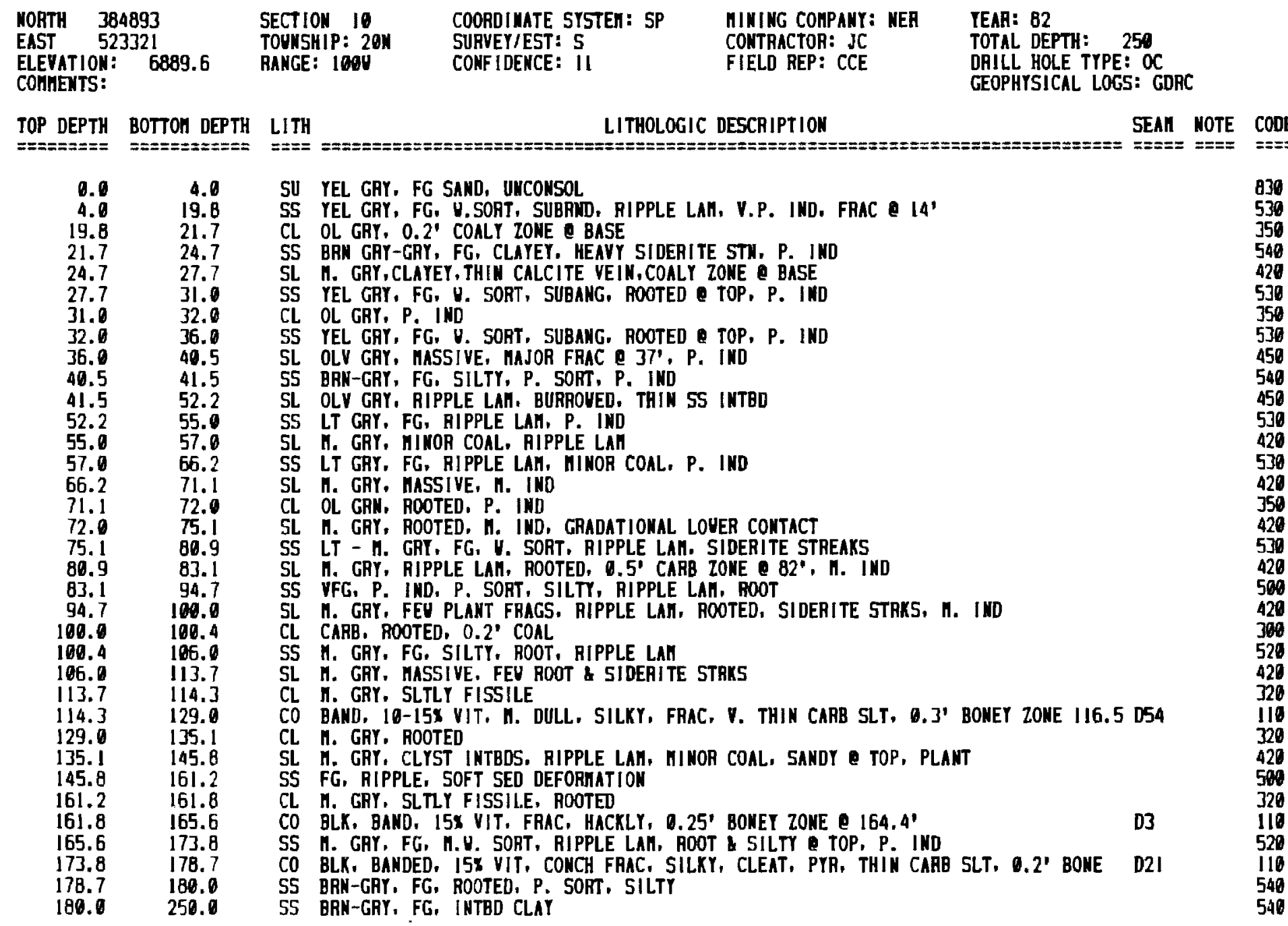


DRILL HOLE NUHBER: 820590BC

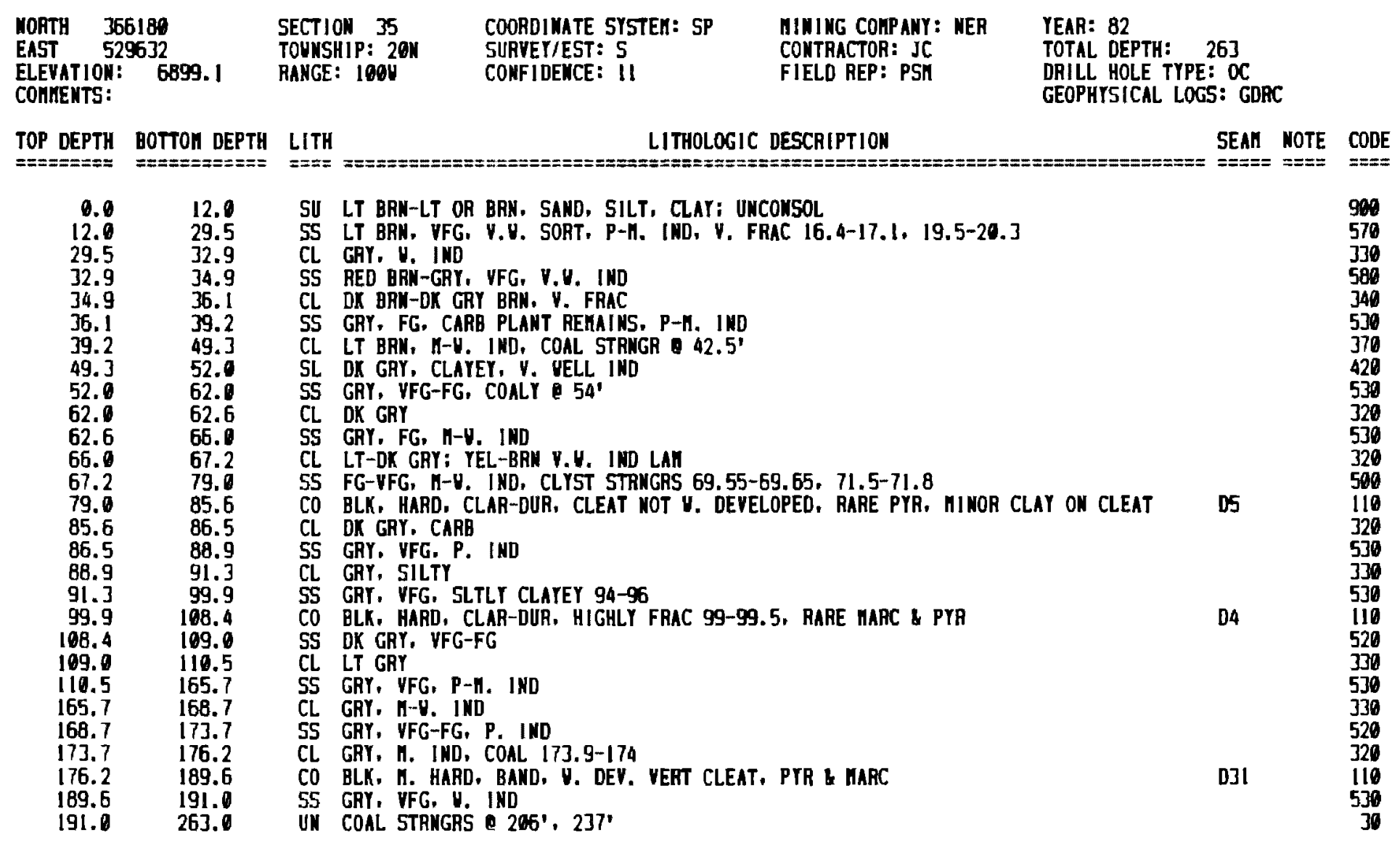


DRILL HOLE NUHBER: 830060BC

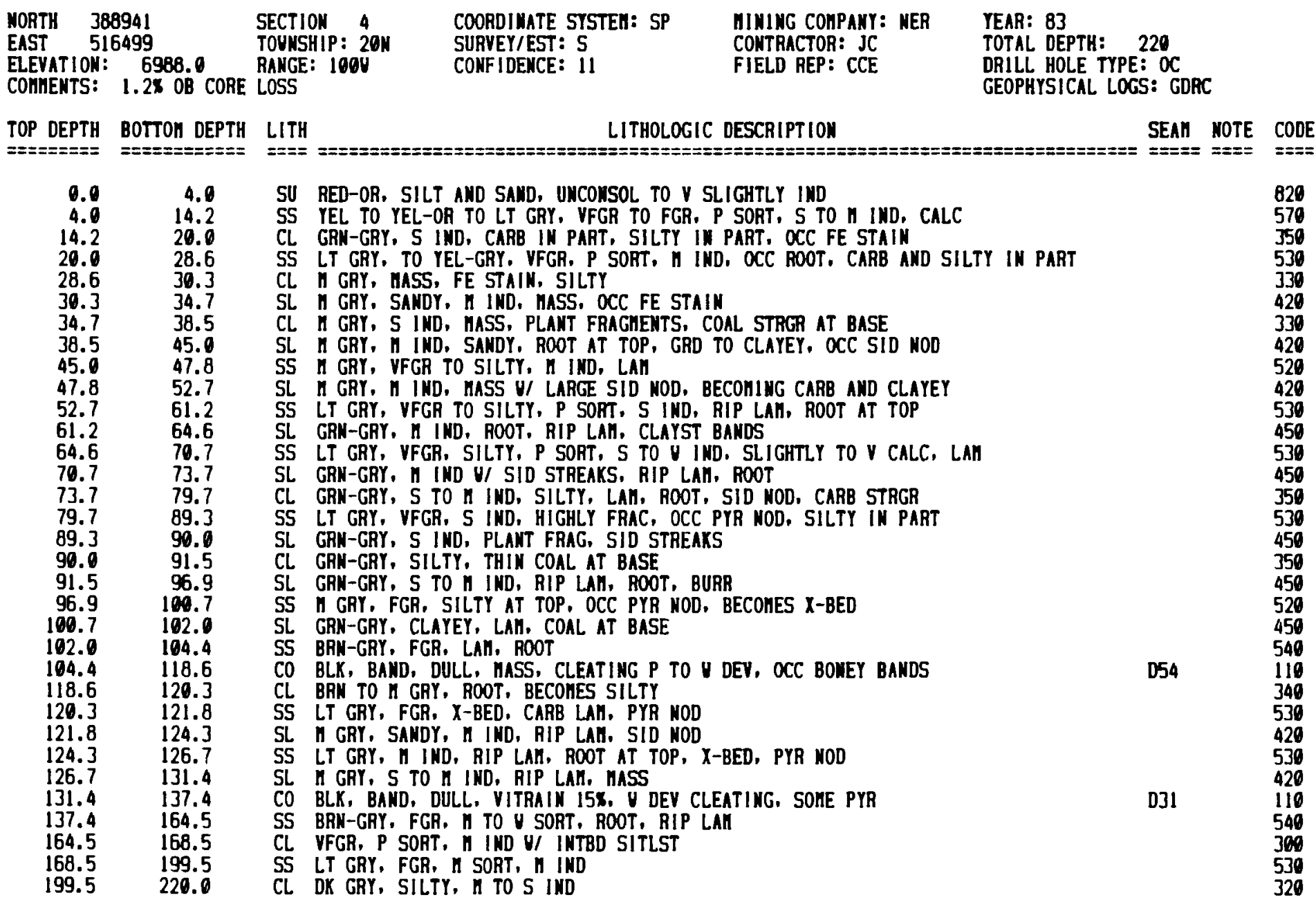


DRILL HOLE NUIBER: B3\%640BC

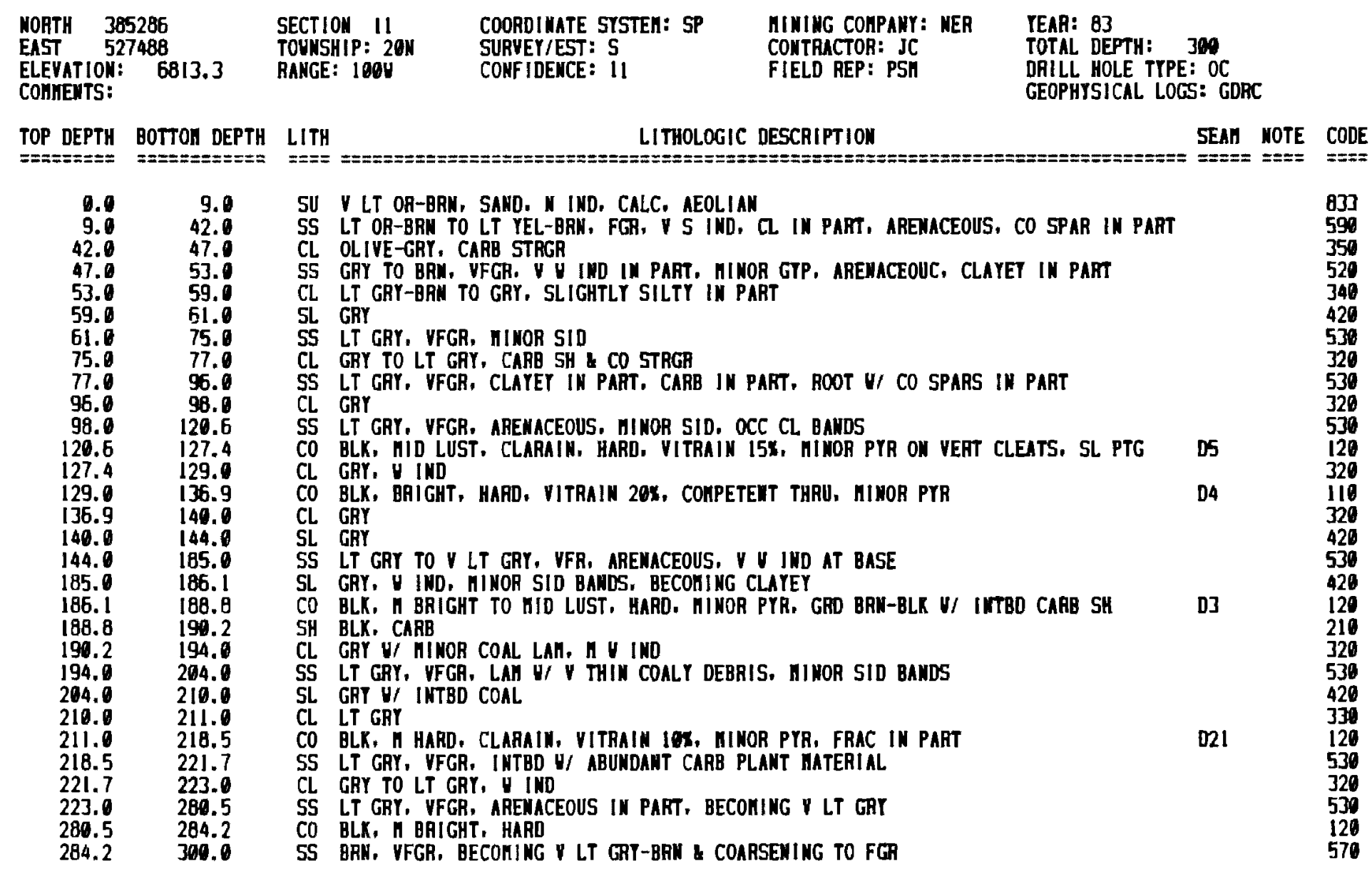


DRILL HOLE NUHBEA: 8501808C

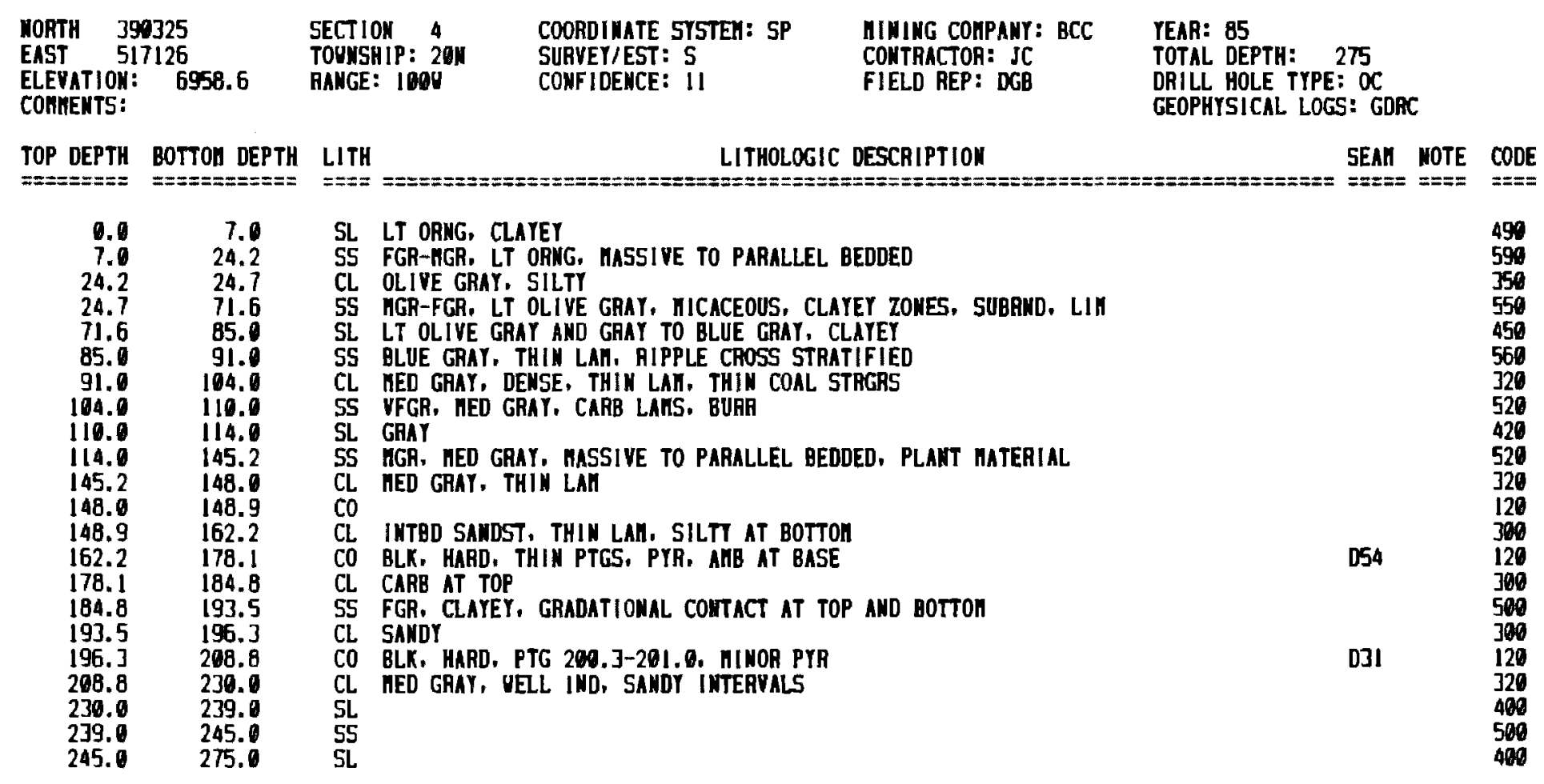


DRILL HOLE NUHBER: $8502208 C$

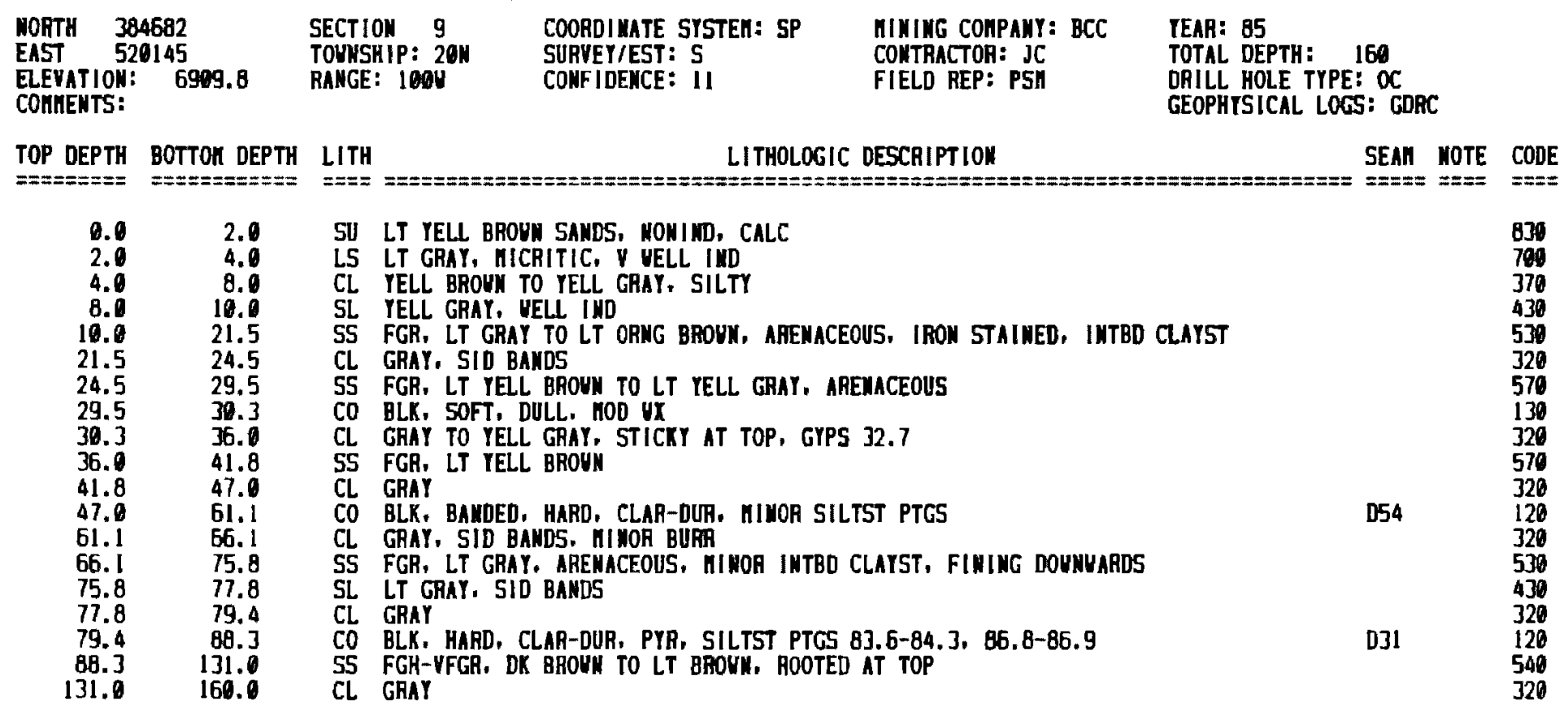


DRILL HOLE NUMBER: $850240 B C$

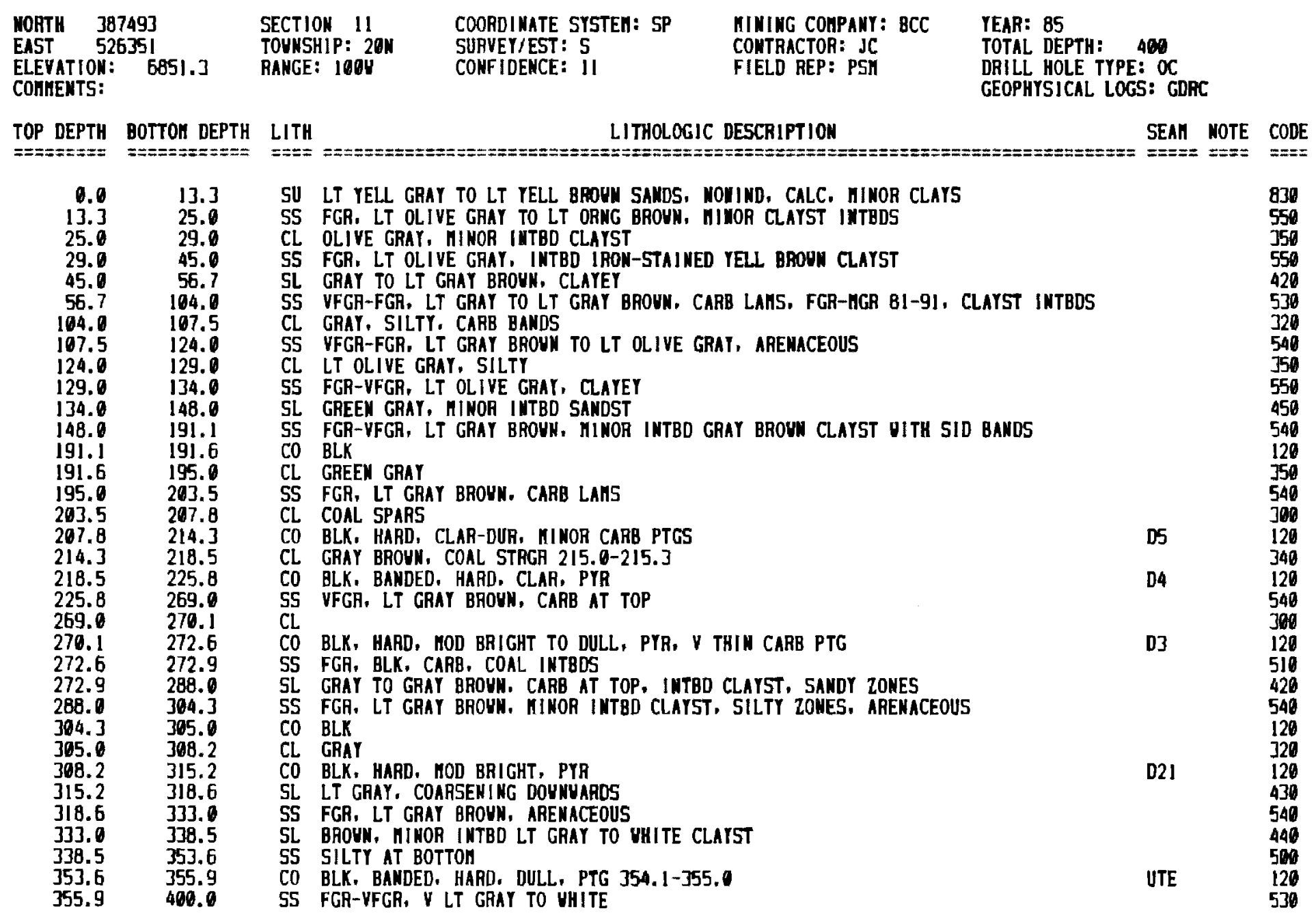


DRILL HOLE WUMBER: B50270BC

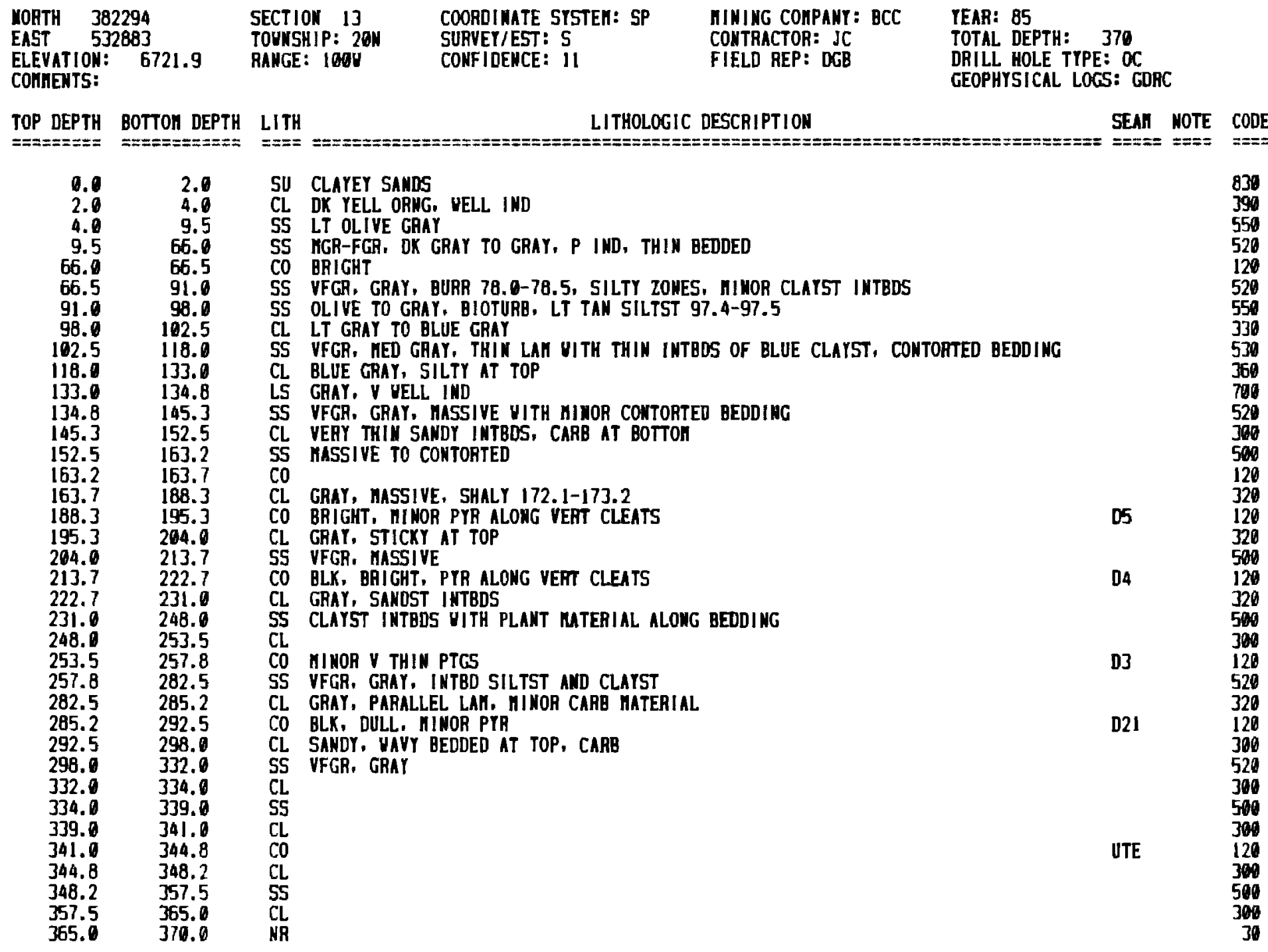


DRILL HOLE MUKBER: $850280 B C$

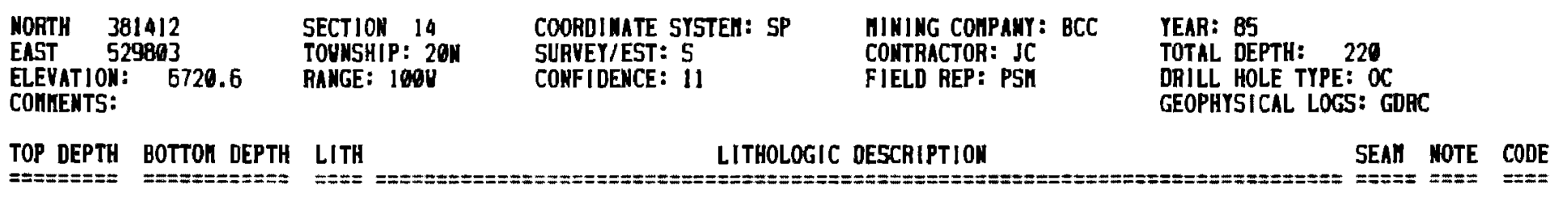

$\begin{array}{rr}0.0 & 8.0 \\ 8.0 & 17.8 \\ 17.8 & 23.0 \\ 23.0 & 28.9 \\ 28.9 & 30.3 \\ 30.3 & 35.5 \\ 35.5 & 36.4 \\ 36.4 & 44.0 \\ 44.0 & 47.3 \\ 47.3 & 54.9 \\ 54.9 & 61.7 \\ 61.7 & 69.2 \\ 69.2 & 83.8 \\ 83.8 & 86.6 \\ 86.5 & 89.8 \\ 89.8 & 95.0 \\ 95.0 & 125.3 \\ 125.3 & 126.2 \\ 126.2 & 132.9 \\ 132.9 & 176.7 \\ 176.7 & 177.5 \\ 177.5 & 220.0\end{array}$

SU V LT YELL BROUN BLOY SAHDS, NONIND, CALC

CL GRAY, SID BANDS, INTED SANDST

SS FGA. LT BROUN, IFON STAIMED

CL LT BAOU,, IRON STAINED, SLTLY SILTY

CO BLK, SOFT, UX

CO BLK, HAAD, CLAR-DUR

CL GRAY

SS FGA, LT BROUN TO LT GRAY, CARB LAHS, BECONING VFGR 41.4

CL GRAY UITH INTBD COAL STRGRS

CO BLX, BANDED, HARD, ClAR

SS FGR, LT BROYN TO LT GRAY, COAL SPARS 54.9-55.5, INTBD CLAYST

$\begin{array}{lll} & & 833 \\ & & 320 \\ & & 570 \\ & & 370 \\ \text { D5 } & \text { UX } & 130 \\ \text { D5 } & & 120 \\ & & 320 \\ & & 570 \\ & & 320 \\ \text { D4 } & 120 \\ & & 570 \\ & 330 \\ & & 530 \\ & 320 \\ \text { D3 } & 120 \\ & & 340 \\ & 530 \\ & & 320 \\ \text { D21 } & 120 \\ & & 540 \\ \text { UTE } & 120 \\ & & 500\end{array}$

CL LT GAAY, MINOR SID BANDS AND INTBD SANDST

SS FGH, LT GRAY, CARB LAMS. SID BANDS

CL GRAY, SID BANDS, SLTLY SILTY

CO BLK, HARD, CLAR-DUR

CL BROUH, STICKY

CL GRAY TO BLK, BROUN I25.5-126.2

CO BLX, HARD, MINOR CARB PTGS, PYA

SS FGR. LT GAAY BROYN, CARB AT TOP YITH COAL SPARS, NINOR INTBD CLAYST

CO

SO 
DHILL HOLE NUNBER: 8503IOBC

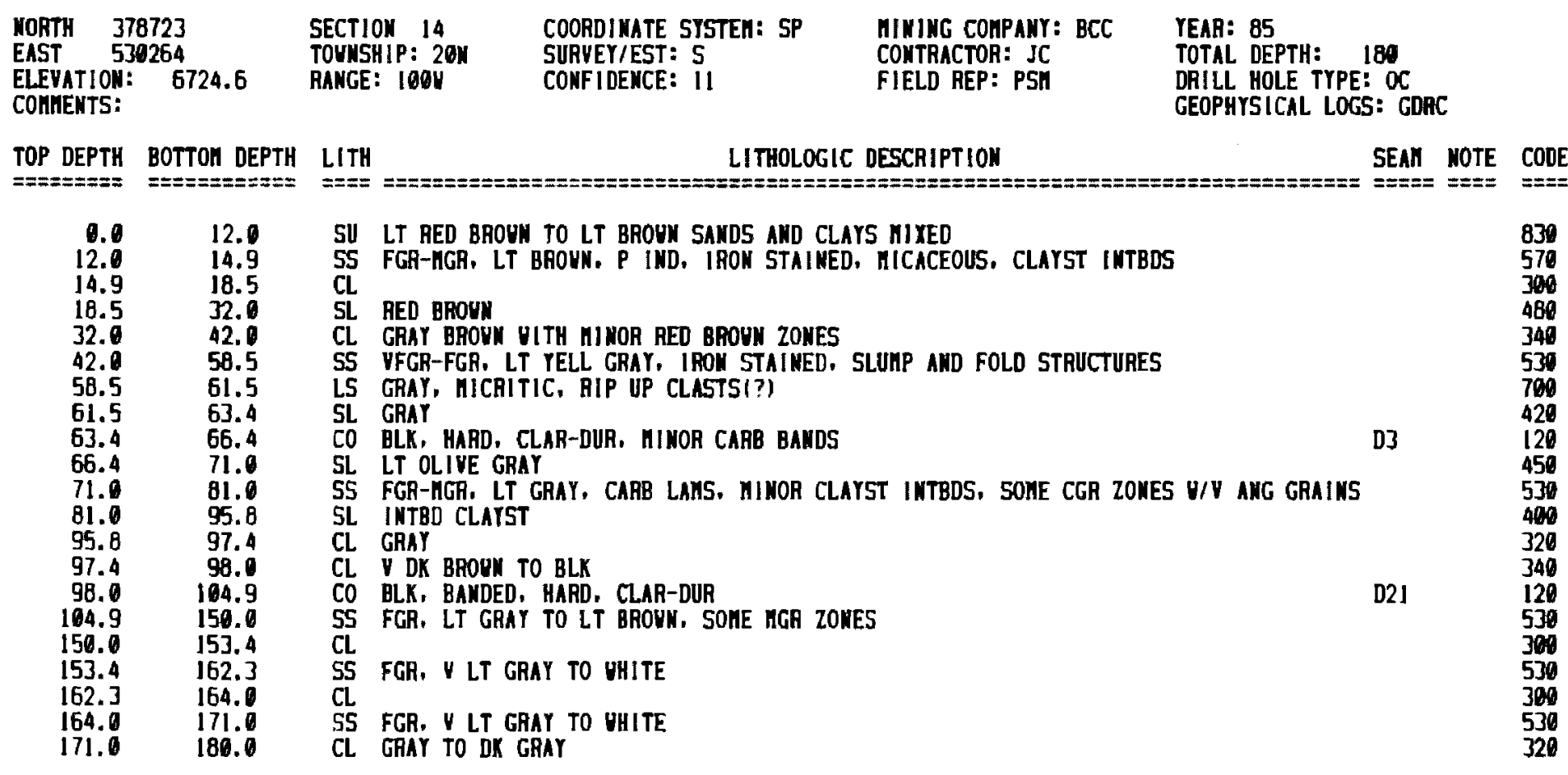


DRILL HOLE MUABER: 850320BC

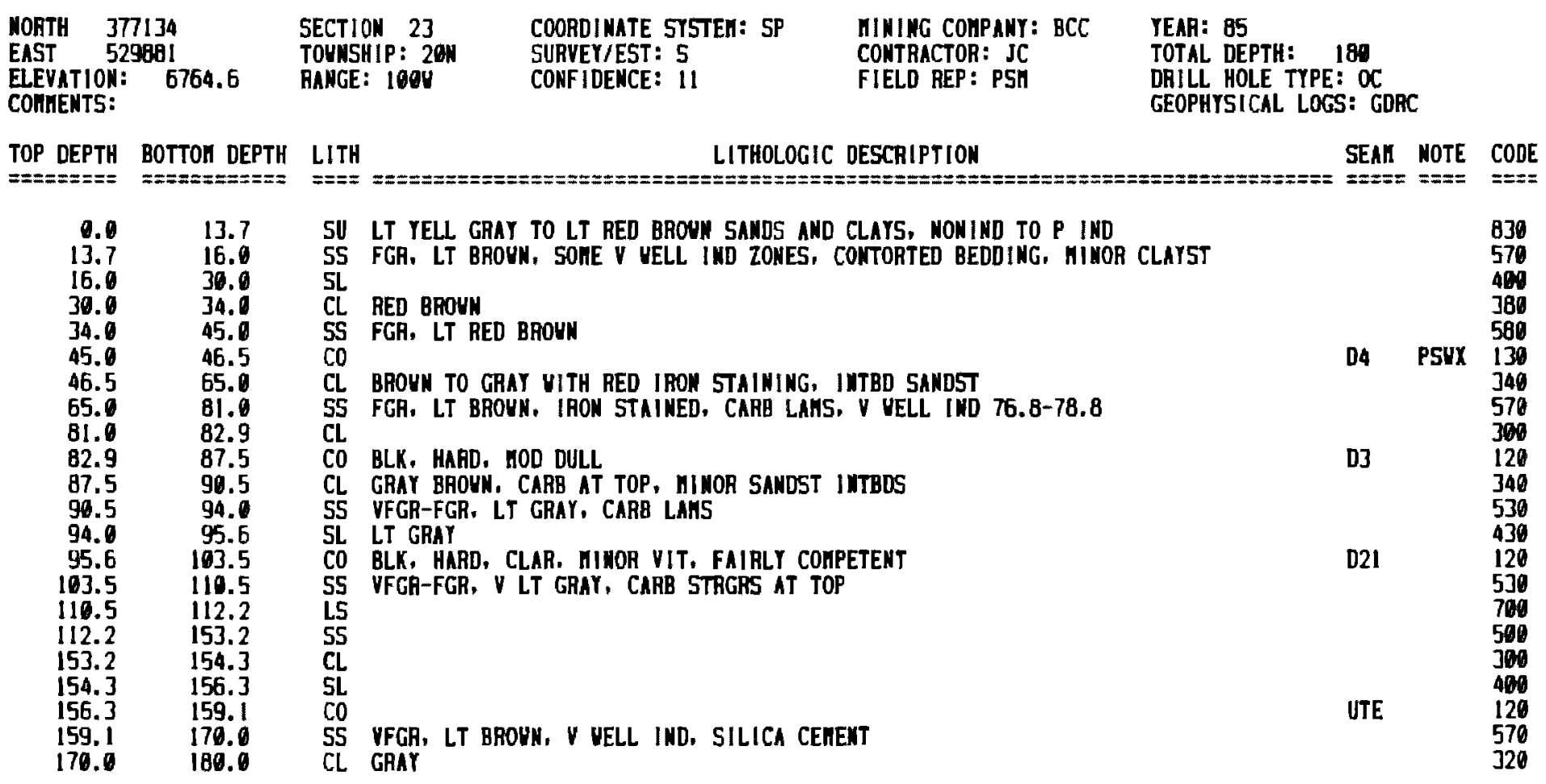


DRILL HOLE NUHBER: $850330 B C$

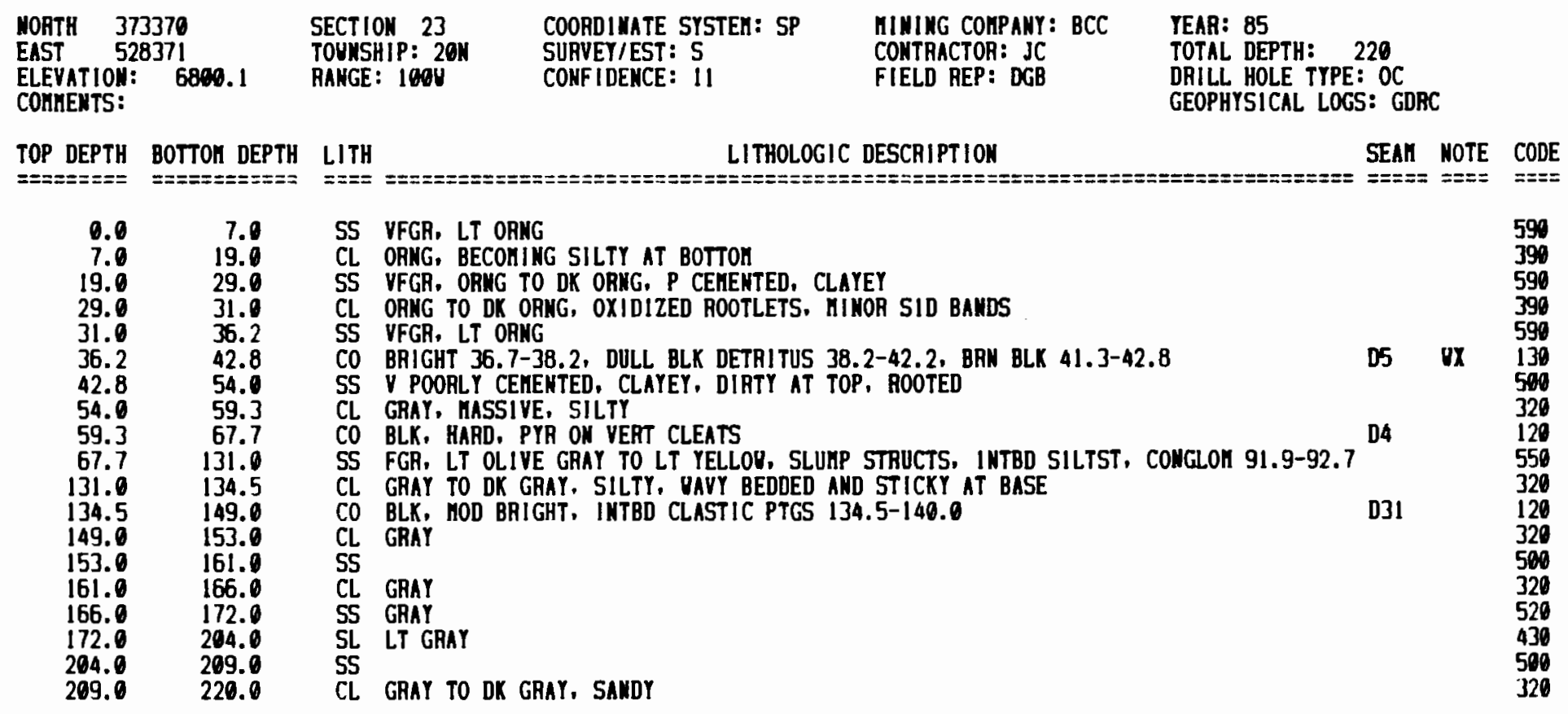


DRILL HOLE WUHBER: 850340BC

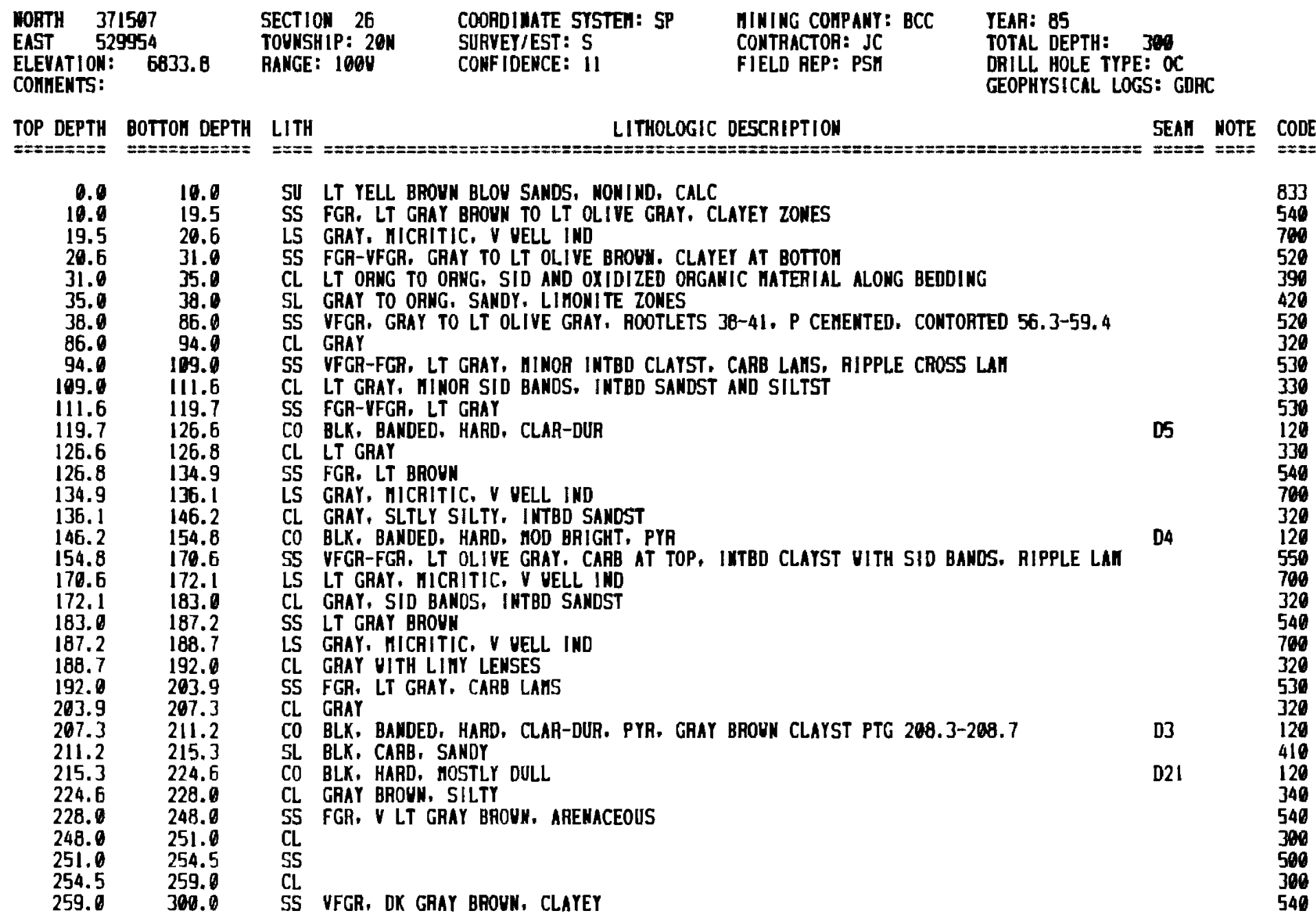


DRILL HOLE WUKBER: 850360BC

\begin{tabular}{|c|c|c|c|c|c|}
\hline $\begin{array}{ll}\text { NOATH } & 3 \\
\text { EAST } & 5 \\
\text { ELEVATION } \\
\text { COHHENTS: }\end{array}$ & $\begin{array}{l}37068 \\
527883 \\
1: \quad 6895.4\end{array}$ & $\begin{array}{l}\text { SECTION } 26 \\
\text { TOUNSHIP: } 20 N \\
\text { RANGE: } 1000\end{array}$ & $\begin{array}{l}\text { COORDIIIATE SYSTEN: SP } \\
\text { SURVEY/EST: } 5 \\
\text { CONFIDENCE: II }\end{array}$ & $\begin{array}{l}\text { MINING COHPANY: BCC } \\
\text { CONTRACTOR: JC } \\
\text { FIELD REP: PSH }\end{array}$ & $\begin{array}{l}\text { YEAR: } 85 \\
\text { TOTAL DEPTH: } 260 \\
\text { DRILL HOLE TYPE: OC } \\
\text { GEOPHYSICAL LOGS: GDAC }\end{array}$ \\
\hline OP DEPTH & $\begin{array}{l}\text { BOTTOA DEPTH } \\
== \pm==\approx=\approx===\end{array}$ & $\begin{array}{l}\text { LITH } \\
===== \pm= \pm==\end{array}$ & 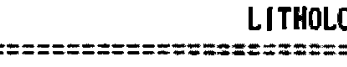 & 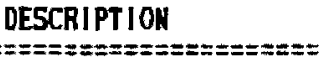 & 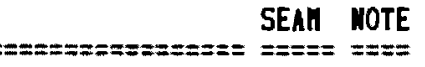 \\
\hline
\end{tabular}

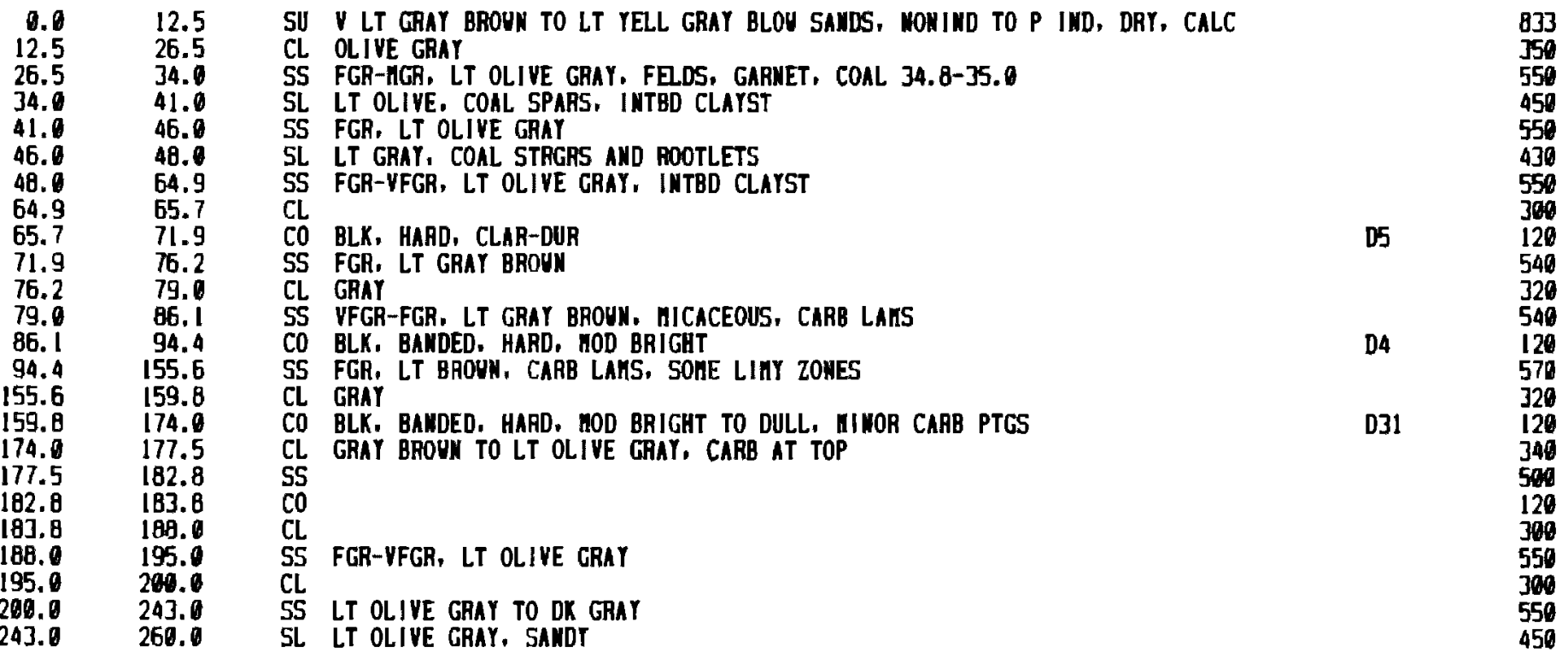


DRILL HOLE NUKBER: 859380BC

\begin{tabular}{|c|c|c|c|c|c|c|}
\hline $\begin{array}{l}\text { NORTH } \\
\text { EAST } \\
\text { ELEVAT 10N } \\
\text { COHAENTS: }\end{array}$ & $\begin{array}{l}367713 \\
528074 \\
\text { on: } \quad 6932.8 \\
\text { 5: }\end{array}$ & $\begin{array}{l}\text { SECTION } 26 \\
\text { TOUNSHIP: } 20 N \\
\text { RANGE: } 1000\end{array}$ & $\begin{array}{l}\text { COORDIWATE STSTES: SP } \\
\text { SURVEY/EST: } 5 \\
\text { CONFIDENCE: } 11\end{array}$ & $\begin{array}{l}\text { MINING COKPANY: BCC } \\
\text { CONTRACTOR: JC } \\
\text { FIELD REP: PSH }\end{array}$ & $\begin{array}{l}\text { YEAH: } 85 \\
\text { TOTAL DEPTH: } 220 \\
\text { DRILL HOLE TYPE: OC } \\
\text { GEOPHYSICAL LOGS: GDAC }\end{array}$ & \\
\hline $\begin{array}{l}\text { TUP DEPTH } \\
=======\end{array}$ & 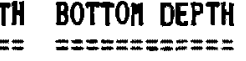 & $L_{== \pm=}^{\text {LITH }}===== \pm=$ & 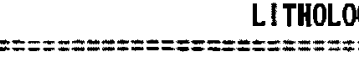 & 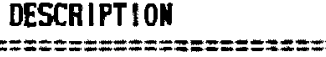 & $=\underset{== \pm==}{\text { SEAH NOTE }}$ & $\begin{array}{l}\text { CODE } \\
===\end{array}$ \\
\hline
\end{tabular}

$\begin{array}{rr}0.0 & 6.5 \\ 6.5 & 19.0 \\ 19.0 & 25.0 \\ 25.0 & 27.4 \\ 27.4 & 43.2 \\ 43.2 & 49.2 \\ 49.2 & 58.0 \\ 58.0 & 50.0 \\ 60.0 & 65.9 \\ 63.9 & 71.7 \\ 71.7 & 91.5 \\ 91.5 & 92.4 \\ 92.4 & 107.0 \\ 107.0 & 109.7 \\ 109.7 & 123.6 \\ 123.6 & 125.8 \\ 125.8 & 139.2 \\ 139.2 & 260.0 \\ 200.0 & 203.0 \\ 203.0 & 220.0\end{array}$

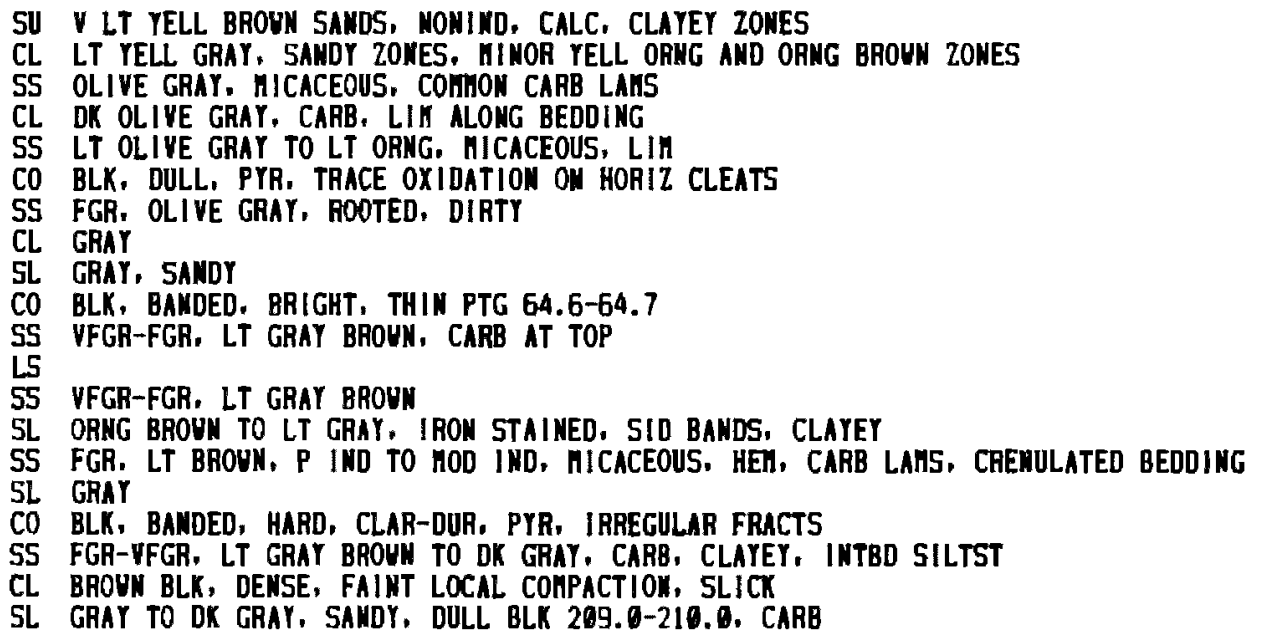


DRILL HOLE NUMBER: 850390BC

\begin{tabular}{|c|c|c|c|c|c|c|c|c|c|}
\hline $\begin{array}{l}\text { NORTH } 365 \\
\text { EAST } 528 \\
\text { ELEVAT ION: } \\
\text { CONHENTS: }\end{array}$ & $\begin{array}{l}5063 \\
9096 \\
6959.8 \\
\text { no GAhi }\end{array}$ & $\begin{array}{l}\text { SECT10 } \\
\text { TOUNSH } \\
\text { RAMGE: }\end{array}$ & $\begin{array}{l}\text { ON } 35 \\
3 I P: 20 \mathrm{~N} \\
: 100 \mathrm{~V}\end{array}$ & $\begin{array}{l}\text { COORDIMATE SYSTER: SP } \\
\text { SURVEY/EST: S } \\
\text { CONFIDENCE: } 11\end{array}$ & $\begin{array}{l}\text { RINING CONPANY: BCC } \\
\text { CONTRACTOR: JC } \\
\text { FIELD REP: DGB }\end{array}$ & $\begin{array}{l}\text { TEAR: } 85 \\
\text { TOTAL DEPTH: } \\
\text { DRILL HOLE TYPE: } \\
\text { GEOPHYSICAL LOGS }\end{array}$ & $\begin{array}{l}210 \\
: 0 \mathrm{C} \\
5: \mathrm{DRC}\end{array}$ & & \\
\hline $\begin{array}{l}\text { TOP DEPTH } \\
=======\end{array}$ & $\begin{array}{l}\text { BOTTON DEPTH } \\
======-==-=\end{array}$ & $\underset{====}{\text { LITH }}$ & 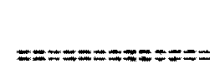 & 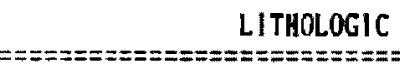 & 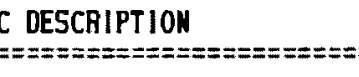 & 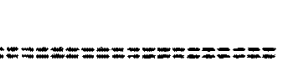 & $\underset{== \pm=}{\text { SEAM }}$ & $\stackrel{\text { NOTE }}{= \pm=}$ & $\underset{= \pm=}{C O D E}$ \\
\hline $\begin{array}{r}0.0 \\
4.0 \\
11.9 \\
12.4 \\
23.7 \\
26.5 \\
33.5 \\
37.0 \\
41.1 \\
52.3 \\
58.0 \\
71.2 \\
79.8 \\
111.5 \\
122.0 \\
135.3 \\
146.0 \\
145.5\end{array}$ & $\begin{array}{r}4.0 \\
11.9 \\
12.4 \\
23.7 \\
26.5 \\
33.5 \\
37.0 \\
41.1 \\
52.3 \\
58.8 \\
71.2 \\
79.8 \\
111.5 \\
122.0 \\
135.3 \\
146.0 \\
146.5 \\
210.0\end{array}$ & $\begin{array}{l}C L \\
S S \\
S S \\
C L \\
S L \\
S S \\
C L \\
C L \\
S S \\
C 0 \\
C L \\
C 0 \\
C L \\
S S \\
C 0 \\
S S \\
C 0 \\
S 5\end{array}$ & $\begin{array}{l}\text { LT OLIVE GRAY } \\
\text { VFGR, LT ORNG } \\
\text { VFGR, DK OANG } \\
\text { LT OLIVE GRAY } \\
\text { OK OLIVE GRAY } \\
\text { FGR-IIGR. LT O } \\
\text { DK OLIVE TO G } \\
\text { LT ORNG TO ORI } \\
\text { FGR-VFCR, LT } \\
\text { OK BROUN ON F } \\
\text { GRAY. THINLY } \\
\text { BRIGHT, WINOR } \\
\text { GRAY TO BLUE } \\
\text { GRAY, INTBO C } \\
\text { BRIGHT, MINOR } \\
\text { FGR, GRAP. FA }\end{array}$ & 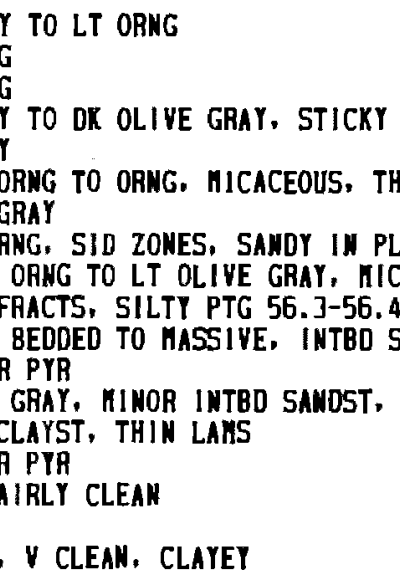 & $\begin{array}{l}\text { I ANO DK ORMG 13.5-14.5, } \\
\text { THIN CARB LAMS } \\
\text { PLACES } \\
\text { ICACEOUS. CALC, SIO BAND } \\
4 \\
\text { SANDST } \\
\text { THIN CARB BEDS, LIM, } 5\end{array}$ & $\begin{array}{l}\text { LIT } \\
\text { 48.0-48.1 } \\
\text { TICKT ZONES }\end{array}$ & D5 & & $\begin{array}{l}350 \\
590 \\
590 \\
350 \\
450 \\
590 \\
350 \\
390 \\
590 \\
120 \\
320 \\
120 \\
320 \\
520 \\
120 \\
520 \\
120 \\
530\end{array}$ \\
\hline
\end{tabular}


APPENDIX 3

PALEOCURRENT DATA 
These paleocurrent directions were measured at three localities in sections 4 and 9, T20N, R100W (Figure 25) on a prominent trough cross bedded sandstone unit in the overburden.

$\begin{array}{ll}060 & 215 \\ 135 & 158 \\ 158 & 163 \\ 040 & 190 \\ 050 & 090 \\ 185 & 135 \\ 170 & 172 \\ 202 & 167 \\ 215 & 138\end{array}$

